\title{
LET'S TALK STORY: WAIKIKI AND ITS SOCIAL DISPLACEMENTS IN ORAL HISTORIES AND PRINT, 1901-1935
}

\author{
A Thesis \\ presented to \\ the Faculty of California Polytechnic State University, \\ San Luis Obispo
}

\author{
In Partial Fulfillment \\ of the Requirements for the Degree \\ Master of Arts in History
}

by

Alika Michael Bourgette

December 2017 
(C) 2017

Alika Michael Bourgette

ALL RIGHTS RESERVED 
TITLE: $\quad$ Let’s Talk Story: Waikiki and Its Social

Displacements in Oral Histories and Print, 19011935

AUTHOR: $\quad$ Alika Michael Bourgette

DATE SUBMITTED: December 2017

COMMITTE CHAIR: $\quad$ Thomas Trice, Ph.D.

Associate Professor of History

COMMITTEE MEMBER: Andrew D. Morris, Ph.D.

Professor of History

COMMITEE MEMBER: Kate Murphy, Ph.D.

Associate Professor of History 


\begin{abstract}
Let’s Talk Story: Waikiki and Its Social Displacements in Oral Histories and Print, 19011935
\end{abstract}

\begin{abstract}
Alika Michael Bourgette
The everyday experiences of Waikiki’s residents of color often escaped official and semi-official records of historical events. When concerning Native Hawaiians and other nonwhite peoples, haole elite journalists and policymakers viewed their land, possessions, and bodies as opportunities for the cultural commodification, sexualization, and reimagination. As part of the redevelopment efforts of the Waikiki shoreline in the early twentieth century, state and commercial actors worked to affect the systematic erasure of Native Hawaiian and resident Asian spaces. This study utilizes extensive collections of oral histories from marginalized Waikiki residents of color to provide counterpoint to notions of indigenous passivity and 'native' savagery perpetuated by hegemonic colonial influences. In conjunction with an "against the grain” reading of print sources, including legislation records, newspaper articles, advertisements, and tourist literature, the study of Waikiki’s oral histories revealed a narrative of everyday resistance and cultural amalgamation in opposition to forces of assimilation and control. Focusing within the first four decades of the twentieth century, the project highlights the social development of Waikiki over that span. It provides vivid reinterpretation of race, ethnicity, sexuality, and gender in the space. The study examines the territorial government's application of biopower against vulnerable, multiethnic populations with
\end{abstract}


respect to immigration and redevelopment, while simultaneously uncovering everyday resistance to that power. 


\section{ACKNOWLEDGMENTS}

Thank you Prof. Trice for your guidance and feedback over the course of the project. To Crystal Smith and Anthony Soliman, I cannot say enough how much your friendship and support has helped me through our program. I would like to give a special thank you and warmest aloha to Mary Yanagihara, my friend on the inside at the University of Hawaii, with whom I traded thoughts throughout the process. Thank you Mom and Dad for your continued well wishes. 


\section{CHAPTER}

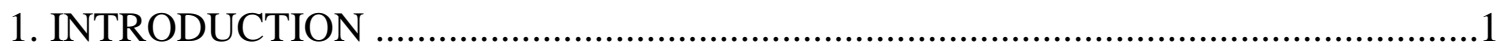

2. THE SOCIAL ENGINEERING OF THE ALA WAI CANAL ……...........................18

2.1. Antiquity to Ala Wai .....................................................................................19

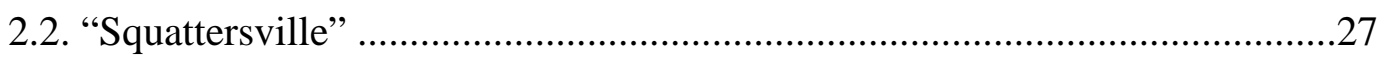

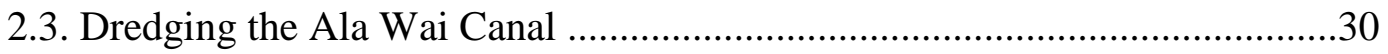

3. JAPANESE IMMIGRATION AND AMALGAMATION ……………………............

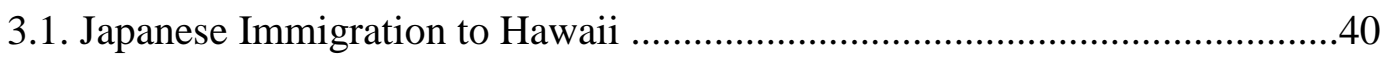

3.2. Predominantly Japanese Housing and Everyday Resistance ............................57

3.3. Waikiki Aloha Kai and Japanese Amalgamation ............................................65

3.4. Japanese Businesses in Hamohamo …………………................................72

4. STONEWALL GANG, BEACHBOYS, AND MULTIPLE MASCULINITIES ........86

4.1. Rascals of Waikiki and the Stonewall Gang ..................................................88

4.2. Hui Nalu, Beachboys, and Sex Appeal ........................................................98

4.3. Fantasies of the Exotic: Gender and Sexuality in Media and Practice ........111

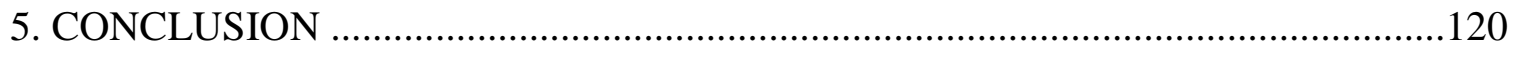

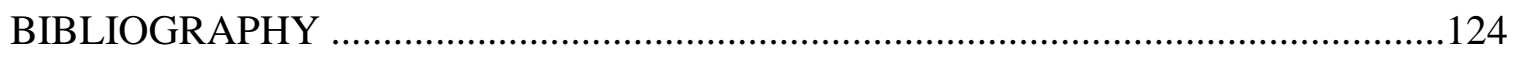




\section{CHAPTER ONE: INTRODUCTION}

“There is a gulf of difference between viewing the Pacific as 'islands in a far sea' and as 'a sea of islands,'” Tongan anthropologist Epeli Hau'ofa informed the reader in his influential essay, “Our Sea of Islands.” ${ }^{1}$ His model, emphasizing the interconnectedness of the peoples of the Pacific Ocean, could be extended to include the continental coasts of Asia and the Americas. Politicians, scholars, and literary authors have all imagined and reimagined maritime space throughout history to better fit their specific agendas. From Alfred Thayer Mahan’s conception of the world's oceans as highways for human and resource exploitation and political domination to Hau'ofa's own call for improved connection and understanding of peoples through the shared heritage of seafaring, waterways provide a nexus for human connection and interaction. ${ }^{2}$ Situated in the center of the world's largest and perhaps most contested ocean, Hawaii often receives depiction as a liminal space, at the same time on the easternmost and westernmost edges of the world. ${ }^{3}$ Within the island chain's rich cultural history, narratives of conquest, colonization, and resistance emerge as consistent themes. Connected to that heritage, the islands’ fame for tourism complicates and sometimes threatens to erase its past. Of Hawaiian vacation destinations, Waikiki stands out in the conversation of touristic excess

\footnotetext{
${ }^{1}$ Epeli Hau`ofa, “Our Sea of Islands,” in E. Waddell, V. Naidu, and E. Hau`ofa, eds., A New Oceania: Rediscovering Our Sea of Islands. (Honolulu: University of Hawaii Press, 1993), 7.

${ }^{2}$ Alfred Thayer Mahan, The Influence of Sea Power upon History, 1660-1783 (London: Sampson, Low, Marston, 1890), and The Problem of Asia and Its Effect upon International Politics (London: Sampson, Low, Marston, 1900).

${ }^{3}$ Literature scholar Rebecca Hogue declared, “At the center of the Pacific Ocean, the Hawaiian Islands experience a liminal identity in the American imagination that is both isolating and alluring” in her article “Cultural Identity and Liminal Places in Contemporary Literature of Hawai ‘i," Rocky Mountain Review 66 (Summer 2012); Travel writer Clayton Hamilton claimed of Honolulu, "It is the most Oriental of Occidental cities, the most Occidental of Oriental” in "Honolulu Holds the Magic Mirror for Mankind.” Vogue, January 1, 1924, 56.
} 
both for its accessibility to a large volume of new visitors and the significant social and physical reengineering it underwent in pursuit of that of that goal.

From sacred ritual grounds to world-class resort destination to package-deal paradise, state political and commercial actors have reinvented Waikiki in their own image. Unique amongst Hawaiian resort experiences, most of which offer privacy and tranquility against breath-taking beaches, Waikiki has an urban soul. Tied to the growth of Honolulu, Waikiki transitioned into a vibrant and modern cityscape in the early twentieth century. A space designated for tourism, Waikiki attracted global attention for its hula dancers, luau shows, and surfing beach boys as demonstrative examples of Hawaiian culture. Branching out from the well-trodden narrative of tourist expectations reshaping and commodifying local culture, this thesis will focus on the ways Waikiki became a space used counter to its original purpose as a hosting grounds for both licit and illicit entertainment. Proceeding in three parts, each devoted to a different geographic space within the resort district, the project will uncover overlapping narratives of local farmers dispossessed of their land and previous ways of life to make way for mainlander socialites and entertainers. By privileging the accounts of everyday life that typically fall outside of the purview of the traditional tourist narrative, I approach the "alternate histories” described by Dipesh Chakrabarty in his work, Provincializing Europe: Postcolonial Thought and Historical Difference. ${ }^{4}$ In that vein, my work connects Waikiki to the broader historiographies and discourse of postcolonial studies and maritime history.

\footnotetext{
${ }^{4}$ Dipesh Chakrabarty, Provincializing Europe: Postcolonial Thought and Historical Difference (Princeton: Princeton University Press, 2000).
} 
Historians have studied the development of Waikiki as both a physical and social construct indicative of broader themes of imperialism, globalization, gender, and body politics. Beginning in earnest at the turn of the twentieth century with the 1901 opening of the Moana Hotel, coastal development would forever reshape the rocky, marshcovered shoreline of Waikiki into a site of mass tourism. As engineering and construction projects reclaimed the shore to its new purpose, Native Hawaiians found themselves displaced from the fertile soils and fishponds that once provided sustenance to urban Honolulu. As tourist culture developed a taste for staged "authentic" experiences, Native Hawaiians and other local people found their interaction within this space again renegotiated as complicit participants in the culture industry. Existing historiography has focused on the sexualized and racialized depictions of Native Hawaiians hula girls and beach boys as part of a dangerous fascination with indigenous culture in the creation of a voyeuristic 'Polynesian Paradise.'

Jane C. Desmond does well to expose the social imaginary developed around Waikiki in her 1999 monograph Staging Tourism: Bodies on Display from Waikiki to Sea World. ${ }^{5}$ Her work uncovered the link between a sexualized exotic and tourist desire in the bodily rendering of the female hula dancer in advertising and live performance. Taking inspiration from Bernard Smith’s concept of “soft primitivism,” Desmond revealed the paradoxical views by which tourists viewed Hawaiian culture as repulsive and uncivilized yet romantic and somehow more closely connected to nature. ${ }^{6}$ Through

${ }^{5}$ Jane C. Desmond, Staging Tourism: Bodies on Display from Waikiki to Sea World (Chicago: University of Chicago Press, 1999).

${ }^{6}$ Bernard Smith, European Vision and the South Pacific (New Haven: Yale University Press, 1985), 5. 
this colonial gaze, Desmond explained the rise of tourism from the mainland in terms of racialization and nation-building. Through advertisements and tourist literature, White Americans wished to experience Hawaii as an outside place "where Hawaiians live and do Hawaiian things," like hula dancing. ${ }^{7}$ The desire to interact with a pre-conceived version of Hawaii through a sexualized and racialized lens helped create a social imaginary through which local people could commodify their own culture to sell as tourist experiences. Isaiah Helekunihi Walker expanded on Desmond's work to include ways in which Native Hawaiian men also become sexualized objects within the tourist industry, and how they exercise power and influence against the traditional racial narrative.

In his work Waves of Resistance: Surfing and History in Twentieth Century Hawaii, Isaiah Walker frames ka po ina nalu, or the surf zone, as a borderlands free from colonial encroachment. ${ }^{8}$ Looking at Waikiki in the early 1900s, he describes the environment as a place where beach boy locals and haole tourists intermingled, but in opposition to the rest of Hawaii outside of this space, here Native Hawaiians and locals maintained their dominance through their surfing prowess. Surfing provided a continuity with the past for Native Hawaiians as a cultural practice that had not been lost during the missionizing process. ${ }^{9}$ With the rise of tourism in the twentieth century, local surfers found new ways to find subsistence by providing entertainment to visitors. Using a gendered approach, Walker demonstrates how beach boys used their sexuality to

\footnotetext{
${ }^{7}$ Desmond, 8.

${ }^{8}$ Isaiah Helekunihi Walker, Waves of Resistance: Surfing and History in Twentieth Century Hawaii. (Honolulu: University of Hawaii Press, 2011).

${ }^{9}$ Walker, 12.
} 
dominate their environment over white tourists. ${ }^{10}$ Targeting wealthy divorcees, daughters of visiting families, and entertainers from the mainland, Waikiki surfers enticed women first into the water, and then into their bedrooms. ${ }^{11}$ In this way, Waikiki beach boys represented masters of both sea and sand in the surf zone. Here again, soft primitivism increased the beach boy's appeal to white women. However, unlike in Desmond's consideration, Walker viewed the Waikiki beachboy as breaking free from the traditional colonial narrative of power. Rather than casting them as feminized and marginalized and ignored in the marketing of Waikiki to a mainland audience, Walker highlighted their sexual prowess and increased agency in the surf zone. Both Desmond and Walker did much to describe the 'forward narrative' of power in Waikiki. Under this model, outside expectations fueled locals’ commodification and reinterpretation of their own culture. The primary discourse of my thesis will challenge this view by providing a ‘reverse narrative’ that views Waikiki not only as a physical space for cultural tourism, but as an urban landscape of opportunity for diverse groups of locals to upend racial and sexual stereotypes and caricatures. The works of postcolonial theorists and scholars, particular as it has been applied to Hawaiian Studies, provide influence into my own inquiry.

Perhaps central to all contemporary scholarship against the traditional colonial narrative in Hawaiian Studies, Noenoe K. Silva’s Aloha Betrayed: Native Hawaiian Resistance to American Colonialism dispelled the myth that Native Hawaiians "passively

\footnotetext{
${ }^{10}$ Walker, 68.

${ }^{11}$ Walker, 98.
} 
accepted the erosion of their culture and the loss of their nation.” ${ }^{12}$ Understanding that traditional archival records, newspapers, government records, and even photographs taken by nonindigenous peoples, present a bias towards the colonial narrative, Silva's work privileged non-written artefacts in the capturing of an indigenous Hawaiian history. Using oral histories, hula, mo 'olelo (legends and stories), and Hawaiian language print media, Silva captured a narrative of resistance and cultural preservation silenced in English-language historical documents. ${ }^{13}$ Borrowing from postcolonial scholars Dipesh Chakrabarty and Partha Chatterjee, Silva looked to the domestic and 'everyday' lives of Native Hawaiians to uncover “alternate histories” unknowable to the haole colonizers, and later tourists, who authored much of the early archival material and scholarship on Hawaiian culture. ${ }^{14}$ Silva’s approach helps Hawaiian scholars reengage with their own culture in terms that no longer privilege the colonizer's narrative and influence over the archival record. The consideration of oral histories and artefact history will help guide my own research in a direction less dependent on written sources that perpetuate a colonial and racialized gaze into Waikiki history. Noenoe K. Silva’s work affirms that a careful reconstruction of both traditional and non-traditional historical sources allows the scholar to approach subaltern voices that struggle to make it to the historical record.

Disappointed by the then-present historiography of Hawaii that depicted Kanaka Maoli, the indigenous people of Hawaii, as having provided "no outspoken protest or resistance against the series of events which appear to have been highly detrimental to

\footnotetext{
${ }^{12}$ Noenoelani K. Silva, Aloha Betrayed: Native Hawaiian Resistance to American Colonialism (Durham: Duke University Press, 2004), 1.

13 Silva, 147.

${ }^{14}$ Chakrabarty, 41.
} 
their well-being,” Haunani-Kay Trask launched a new critical line of inquiry into the past of Native Hawaiians that eschewed the colonizing influence she believed continued to plague the field through biased primary sources and unimaginative scholarship that took them for face value. ${ }^{15}$ Regarding such works as "the West's view of itself through the degradation of [her] own past,” Trask exposed a gross disregard for Hawaiian-language periodicals within the field of Hawaiian history. By poring through a wealth of preserved Hawaiian-language newspapers spanning much of the nineteenth century, Trask observed the forced deterioration of the Hawaiian language. As the haole families that constituted the social elite consolidated power and influence, culminating in the 1983 overthrow of the monarchy, the Hawaiian language suffered gradual loss of prestige and accord until its explicit ban from public and private schools under the Provisional Government of the Republic of Hawaii in the same year. ${ }^{16}$ Trask's investigation into the vibrancy of Hawaiian-language print culture in the nineteenth century underscored the process of linguicide and cultural destruction that persisted until late-twentieth century efforts to resuscitate Hawaiian culture from its state of erasure. Deeming the movement for the preservation of Kanaka culture the "Hawaiian Renaisance," scholars, politicians, and activists, Trask among them, performed exacting work to preserve practice, artefacts, and traditions from their complete erasure. This work benefits from the efforts of such scholars, especially in its use of oral histories recorded in the late-twentieth century as part of the preservation effort.

\footnotetext{
${ }^{15}$ Haunani-Kay Trask, From a Native Daugther: Colonialism and Sovereignty in Hawai ' $i$ (Monroe: Common Courage Press, 1993).

${ }^{16}$ Trask, 53.
} 
The University of Hawaii Center for Oral History, part of the College of Social Sciences and Social Sciences Research Institute, has recorded the recollections and experiences of the people of Hawaii since 1976 after its establishment by State Legislature. Under the stewardship of Program Director Warren S. Nishimoto, the Center for Oral History has embarked on thirty-five extensive projects covering topics ranging from remembrances of tsunamis throughout the twentieth century to the state of public education in Hawaii to women workers in the pineapple industry. Since its inception, the Center for Oral History has interviewed over 800 individuals, resulting in over 36,000 transcript pages archived. ${ }^{17}$ Among those, the fifty-one interviews that comprise the collection entitled, Waikiki, 1900-1985: Oral Histories provide central context to much of this work to which the author is indebted. ${ }^{18}$ Recording the memories of Japanese new arrivals who worked as laundresses and hotel workers, as well as those of neighborhood pranksters who became Waikiki’s first beachboys, the tireless work of interviewers Warren S. Nishimoto, Michi Kodama-Nishimoto, and Iwilani Hodges provided rich nuance to the archival registers of Waikiki from the vantage of the everyday people who called the district home. The pages generated by the Center's projects expands upon the historical record of the past by providing a level of intimacy and personality often missed by print media alone. Oral histories have the potential to illuminate new details to historical events in clarity missed or misrepresented in archival materials produced and curated by persistent hegemonic influences, as encountered by

\footnotetext{
${ }^{17}$ Michi Kodama-Nishimoto, Warren Nishimoto, and Cynthia A. Oshiro, Talking Hawai 'i’s Story: Oral Histories of an Island People. (Honolulu: University of Hawaii Press, 2009), xiii.

${ }^{18}$ Oral History Project, Waikiki, 1900-1985: Oral Histories. Volumes 1-3. (Honolulu: Center for Oral History, Social Science Research Institute, University of Hawai'i, Manoa, 1985-1986).
} 
Trask. However, by their very nature as stories told through the lens of memory, oral histories have the ability to obscure or confuse details recounted so far removed from their occurrence. Taking a negotiated stance, this thesis contextualizes evidence from oral histories against print sources, including legislation records, newspaper articles, advertisements, and tourist literature. By reading print records “against the grain,” as suggested by Edward Said, in conjunction with a conscious reading of oral histories, a narrative of everyday resistance by the Native Hawaiian and local nonwhite populations of Waikiki arises. ${ }^{19}$

Michel de Certeau and James C. Scott both looked at the practice of 'everyday' habits and rituals by subjugated peoples, finding within them patterns of resistance to assimilation into the dominant culture. Questioning the success of Spanish colonizers' cultural dominance over the American Indian population, de Certeau stated, "the Indians nevertheless made of the rituals, representations, and laws imposed on them something quite different from what their conquerors had in mind; they subverted them not by rejecting or altering them, but by using them with respect to ends and references foreign to the system they had no choice but to accept.”20 Acknowledging active forms of resistance, such as armed insurrection, as often outside of the capabilities for a dominated population, de Certeau offered that within the observance of expected norms and behavior for society subjects had room to resist in ways invisible to the dominant caste. James C. Scott arrived at similar conclusions in his observations of class conflict in the rural Malaysian village of Sedaka. During his eighteen months amongst the local

\footnotetext{
${ }^{19}$ Edward W. Said, Orientalism. (New York: Vintage Books, 1979).

${ }^{20}$ Michel de Certeau, The Practice of Everyday Life, trans. Steven Rendall (Berkeley: University of California Press, 1984), xiii.
} 
population, Scott observed a propensity for "offstage” comments and conversations, "proverbs, folksongs, and history, legends, jokes, language, ritual, and religion,” as key indicators of everyday resistance that eluded detection from social elites. ${ }^{21}$ In Hawaii, offstage or otherwise veiled forms of resistance facilitated the emergence of a multicultural working class. Everyday shared experiences of repression and success told through the common medium of talking story, or unguarded banter in Hawaiian Pidgin, forged bonds between the previously disparate peoples who arrived in Hawaiian as laborers for the sugarcane and pineapple industries. In his observations of the dynamic between oppressor and oppressed, Scott further noticed abuses perpetrated by the state for the purported benefit of the people.

James C. Scott’s analysis of state-initiated social engineering projects throughout the twentieth century, including Soviet collectivization, China's Great Leap Forward, and the U.S.-led Green Revolution in Southeast Asia, revealed the attempts by the modern state to remodel the natural world to fit prescribed, legible patterns. ${ }^{22}$ Through the increased efforts of census taking and mapmaking, Scott observed the concurrent efforts in the Westernized world towards standardization of both the body and environment. While improving the state's ability to tax and conscript its subjects, regularization of the environment caused problems for local communities. Focusing on societal level efforts towards improving human condition in the areas of public health, education, and commerce, state-run social initiatives often ignored, and sometimes preyed upon, the

\footnotetext{
${ }^{21}$ James C. Scott, Weapons of the Weak: Everyday Forms of Peasant Resistance. (New Haven: Yale University Press, 1985), 41.

${ }^{22}$ James C. Scott, Seeing Like a State: How Certain Schemes to Improve the Human Condition Have Failed. (New Haven: Yale University Press, 1998), 3-4.
} 
needs of the constituents they aimed to serve. ${ }^{23}$ In the case of the redevelopment of Waikiki in the early twentieth century, the state perpetrated abuses against its subjects in the name of public health, pointing the 'unsafe and deleterious' conditions of the low lying wetlands as a reason to dispossess Native Hawaiian and local Asian farmers from their land and livelihoods. Through the vast reengineering of the landscape, the territorial government conspired to transform the environment into a tourist paradise that satisfied the state's definition of public safety through the removal of disease pressures and undesired population. Concerns for public health veiled an underlying racialized policy that aimed to benefit the haole elite at the expense of subjugated nonwhite populations. Using abusive state power and everyday resistance to its influence as its methodological backdrop, this thesis uncovers the submerged narratives of Waikiki's displaced residents. Neither passive nor silent, the voices on display challenge the narratives privileged by the haole elite that attempted to erase them.

In Hawaii, talking story encompassed more than chatting, gossiping, or shooting the breeze. Taking part in such conversation bound its participants together. When residents of Hawaii talk story amongst one another, they acknowledged their bond to each other as a source of identity. Talking story happened in informal spaces removed from official control. The practice demonstrated the uneven application of dominance, revealing spaces and time to which 'local' people could return and take a brief reprieve from colonial oppression. Even more telling, talking story in part provided definition to the ‘local' identity. In a political environment where being ‘Hawaiian’ had attached ethnic as well as demographic connotations, the identifier 'local' arose to demarcate

\footnotetext{
${ }^{23}$ James C. Scott, Seeing Like a State, 57.
} 
those who had an intimate attachment to the modern culture of Hawaii without claiming or appropriating Native Hawaiian ethnicity. Each of the recorded oral histories used in this project have been collected in the tradition of talking story. Collected from the comfort of each participant's home, the interviewers captured conversations over multiple sessions, following the subject's personal train of thought. The transcripts of the recorded conversations retained a sense of intimacy, capturing the subject's pauses, laughter, and even interruptions such as a ringing telephone or loud vehicle in the background. ${ }^{24}$ In such instances, the narration paused, backtracked, and resumed as one would in a natural conversation between friends. Wherever possible, this project aimed to replicate organic conversations by retaining all annotations provided by the Oral History Project. To preserve the intimate nature of the shared conversations, I refer to oral interview subjects by their given names, or both given and last names, rather than by their surnames alone. Taking a personal aside as author of the project, after reading through hundreds of transcript pages, I felt connected to both the interviewers and subjects who opened their living rooms and lives to those who would engage with their stories. I gained the impression that such magnanimous characters as Hamohamo neighborhood prankster "Rusty” Holt and jet-set entertainer and beachboy "Turkey” Love would object to having their identities reduced to such essential categories as their family names. As the reader forms the same intimate connections to the characters uncovered by this work, I hope that they, too, feel engaged with their stories.

The thesis proceeds in three parts, with each division favoring a spatial or thematic category over chronological narrative. Focusing within the first four decades of

\footnotetext{
24 Oral History Project, “Introduction,” in Waikiki, 1900-1985: Oral Histories, 11.
} 
the twentieth century, the project highlights the social development of Waikiki over that span. It draws sources from archived print media, periodicals, legislative records, and literature, while giving heavy consideration to collected oral histories. The University of Hawaii at Manoa Center for Oral History has embarked on a rich project of cataloguing Hawaiian and local voices on a vast multitude of topics, making the transcripts freely available online. Perhaps most pertinent amongst their collections, Waikiki: 1900-1985 contains fifty-one collected oral histories from many viewpoints, capturing narratives from beachboys, musicians, hotel and hospitality workers, police officers, business owners, government officials, and federal and military employees. ${ }^{25}$ The interviewees tell the stories of the rapid changes Waikiki underwent over the twentieth century, recalling the pre-development days of at the turn of the century to the rise of the tourist industry, marking lifestyle changes including taking on jobs in hotels or running shops and restaurants catering to the evolving tastes. The oral histories contained within the collection appear consistently throughout each section of the thesis, providing continuity in methodology.

Using the 1921-1924 Ala Wai Canal project as a lens into early tourist development, the first chapter of the thesis uncovers the reengineering of rural Waikiki into an urban vacation landscape. Through oral histories, newspaper articles, and legislative records, the section will build an image of Waikiki in turbulent transition. Wetland farmers share their experience with displacement from their lands as dredging crews reshape the district. Newspaper coverage and legislative archives reveal the racialized nature behind the removal of locals to affect economic gain for a handful of

${ }^{25}$ Oral History Project, Waikiki, 1900-1985: Oral Histories. 
White American actors in control of both commerce and government in Hawaii. The chapter looks in-depth into the Kalia neighborhood and its adjacent "Squattersville” camp for Native Hawaiian families. The chapter also describes the the dredging project, outlining its physical parameters and legislative history, while drawing out first-hand accounts from a Waikiki resident who worked as a dredge operator, giving local perspective to the redevelopment project.

The following chapter delves deeper into the daily lives of Waikiki residents of Japanese descent during the region's transition into a tourist zone. Focusing primarily on the Hamohamo neighborhood, the chapter unveils its successive transformations from the vacation estate of Queen Liliuokalani to quiet neighborhood for Native Hawaiian and issei Japanese families, to high-density housing for lower-income families. Looking first at immigration stories from the neighborhood's Japanese immigrants, the chapter uncovers racialized quarantine policies meant to define national boundaries along spatial and medical lines meant to exclude undesired, nonwhite bodies from incorporation. Oral accounts of cultural amalgamation into multiethnic rural plantation and urban workingclass society reveal a counter to nativist, xenophobic, and populist rhetoric that labeled Japanese arrivals as permanent outsiders incapable of coexistence within American culture. Shared cultural practices and activities, including talking story, between Japanese and other nonwhite populations of Hamohamo crafts a narrative of everyday resistance to cultural colonization. Through community outreach organization and broad, multiracial participation in cultural events such as bon odori, the Japanese mid-summer festival, the amalgamation of Japanese, Native Hawaiian, and other ethnic working-class cultures becomes apparent. 
The focus then shifts towards Japanese shop owners, looking at their adaptation to a more urban lifestyle after the dredging of the Ala Wai Canal. In particular, stories from oral histories shed light on the Unique Lunch Room and the Aoki Store as two examples of issei Japanese immigrants finding footholds in the local economy. As hotel development pushed lower income residents into smaller tracts of land, the Hamohamo neighborhood emerged as a locus for working-class families. The chapter uncovers the broad scale acceptance of Japanese businesses by the neighborhoods Part-Hawaiian population. Promoting the success of Japanese-owned businesses in Honolulu, organizations such as the Japanese Chamber of Commerce provided community service and outreach. The efforts of the Japanese Chamber of Commerce combated continued discourse of "yellow peril" and ethno-nationalism that excluded Asian Americans from citizenship and equal rights under the law.

The final chapter develops a picture of how outsiders, primarily U.S. mainland haoles, perceived Native Hawaiians and their bodies through tourist literature and images. In service to the burgeoning tourist industry, haole journalists and travel writers painted the young Native Hawaiian men of Waikiki as alternatively "the perfect servants" or “drunken derelicts.” Negative depictions of Hawaiian masculinity served to draw distinction between white rationality and morality and 'native' savagery and backwardness. American literary figures, including Mark Twain, Robert Louis Stevenson, and Jack London, introduced Hawaii to a mainland audience through racialized depiction of their own touristic experiences. Literary examples, in turn, influenced tourist literature produced for Hawaii, shaping the way Waikiki tourism would develop. In particular, Jack London's depiction of Native Hawaiians as friendly and 
courteous, yet primitive became an established caricature for nonwhite peoples of Hawaii. ${ }^{26}$ Early tourist literature crafted a romanticized vision of Hawaii, promoting its exoticism through racialized observations. Travel writers romanticized Hawaii as a timeless land immune to the ravages of modernity, finding the idyllic pace of live an "escape from the habitual." ${ }^{27}$ The chapter counters such limited views through a deep analysis of oral accounts from resident troublemakers-turned-beachboys. By privileging the oral accounts of Native Hawaiian men who grew up in Waikiki over the biased, racist accounts offered by print media alone, this chapter aims to reconfigure gender and sexuality within the space of Waikiki along, capturing a complex image of the manifold masculinities present and how they contributed to commerce, crime, and sexual interaction within the tourist district.

The study of Waikiki through its social displacements provides a novel gaze into the history of the region. It parts ways with the existing historiography of the physical development of Waikiki by privileging the accounts of locals while applying a scrutinizing lens to the hegemonic powers that have dominated the discourse surrounding the topic. The study of "alternative histories" and "everyday resistance” within colonial cityscapes has gained popularity with historians and social scholars in the last forty years. This project links Honolulu to this rich existing historiography, broadening its appeal beyond the interests of Hawaiian history. The twentieth century saw the physical redevelopment of shorelines throughout the world to touristic pursuits. In such places,

${ }^{26}$ Jack London, “A Royal Sport” in The Cruise of the Snark: Jack London's South Sea Adventure. (Santa Barbara: Narrative Press). 2001. 50.

${ }^{27}$ Clayton Hamilton, “Honolulu Holds the Magic Mirror for Mankind.” Vogue. January 1, 1924. 56. 
consistent themes persisted such as commodification of indigenous culture, the sexualization of their bodies, and the reimagining of space to cater to manifold desires. By centering discussion on a single district within a city on the periphery of most conceptions of political space, this study highlights indigenous voices and issues complicating the preservation of Hawaiian culture while also framing Waikiki within greater, global trends of mass entertainment. The oral histories of Waikiki residents revealed accounts of everyday resistance to cultural colonization and racialized depictions of inferiority and disunity as perpetuated by the haole elite. 


\section{CHAPTER TWO: THE SOCIAL ENGINEERING OF THE ALA WAI CANAL}

Oh, well, there were a lot of Hawaiian people living around there. We moved to a corner lot. It was one big house and that was all [there was] in this big area. It was a little over two acres we had in the corner there and only one house. Then later on my father put up some duplexes and rented them out. Then he put up a couple of cottages. But he didn't put anything else after that because we had the fishpond. ${ }^{28}$

Kalia Resident Ella Ling Wong, 74, retired schoolteacher

In the Kalia neighborhood of Waikiki, fishponds and taro fields dominated the landscape at the turn of the twentieth century. Farmers and squatters alike lived amongst thickets of kiawe (Prosopis pallida, a species of mesquite) and dried coral. The lowlands of Kalia blurred the boundary of land and shore. Strong storms would be rushing waters that crested over natural streams, flooding homes and dropping silt and deposits from the mountains four miles away. The territorial government saw the periodic flooding as a nuisance to development. The residents of Kalia, however, came to depend on the waters for their livelihoods. The two concerns collided after the 1898 annexation of Hawaii by the United States. Emboldened by federal support, the crafters of the Revised Laws of Hawaii, the codified statutes of the territory, included provision to "seize and improve" any such land deemed “deleterious to the public health in consequence of being low, and at times covered or partly covered by water...or for other reason in an unsanitary or dangerous condition.”29 Racialized biases against the incumbent residents of Kalia motivated territorial officials and industrialists to move forward with a redevelopment plan that would reshape the landscape. The 1921-1924 Ala Wai Canal project found its

\footnotetext{
${ }^{28}$ Ella Lila Wong, oral history interview with Warren Nishimoto, June 16, 1986, Honolulu, O‘ahu. In Waikiki, 1900-1985: Oral Histories Vol. 1 (Honolulu: Center for Oral History, Social Science Research Institute, University of Hawai‘i, Manoa, 1986), 1819.

${ }^{29}$ Revised Laws of Hawaii: Comprising the statutes of the Territory, consolidated, revised and annotated (Honolulu: T.H. Hawaiian Gazette, 1905), 455.
} 
roots in decades of legislative and economic history centered around the desire to develop Waikiki into a premium resort locale.

This chapter utilizes oral histories, newspaper articles, and legislative records to provide narrative to the turbulent changes brought to the landscape and livelihoods of its occupants. Wetland farmers share their experience with displacement from their lands as dredging crews reshape the district. Newspaper coverage and legislative archives reveal the racialized nature behind the removal of locals to affect economic gain for a handful of White American actors in control of both commerce and government in Hawaii. The chapter looks in-depth into the Kalia neighborhood and its adjacent "Squattersville” camp for Native Hawaiian families. The chapter also describes the the dredging project, outlining its physical parameters and legislative history.

\subsection{Antiquity to Ala Wai}

The popular, present-day image of Waikiki Beach, of waving palms against a white, sandy shore looking out toward the lush, green peak of Diamond Head in the distance, would appear unrecognizable to onlookers from a century ago. Waikiki's name, which translates as "place of spouting water," harkens back to the artesian springs and flowing streams that used to feed the fertile lands. Prior to the 1920s and the construction of the Ala Wai Canal, the lowlands of Waikiki served as important agricultural grounds, where fishponds and taro fields provided sustenance to the inhabitants of a burgeoning Honolulu. Upon their final approach to shore, new arrivals to Honolulu Harbor passed by the quaint farming lands of Waikiki and saw a fleeting reminder of the island's agrarian 
past. ${ }^{30}$ By the turn of the twentieth century, the city that surrounded Waikiki had developed into a modern metropolis where streetcars clanged and crowds formed and dissipated with the traffic of daily life. Waikiki, however, avoided such development. The broad-leafed taro rustled in the wind, surrounding the country homes where the ruling $\operatorname{ali}^{\top} i$ had once vacationed. In the days before modern tourism, Waikiki had already become recognized as a place for relaxation and enjoyment.

At Helumoa, the present-day site of the Royal Hawaiian Hotel, sat the Royal Palm Garden, a collection of over 10,000 coconut palms that found its origins in the antiquity period of Hawaiian History. The grove had religious importance to early Native Hawaiians, who had constructed heiaus (temples) on the land, and made the land accessible only to the high-ranking chiefs of Oahu. Upon his unification of the Hawaiian Islands in 1810, King Kamehameha I selected Helumoa as his administrative center on the island. ${ }^{31}$ After Kamehameha I's reign, Helumoa fell out of religious use, but remained a royal residence for his descendants. Access to fresh water and a secluded beach, along with the shade and privacy afforded by the Royal Palm Garden made Helumoa a favorite retreat for Hawaii’s rulers, who had relocated official residence into Honolulu proper. King Kamehameha V (1863-1872) developed for his personal use the parcel that would become the Royal Hawaiian Hotel. The land today remains held in trust by the estate of Princess Bernice Pauahi Bishop, one of the largest and wealthiest land-holding trusts in Hawaii ${ }^{32}$.

\footnotetext{
${ }^{30}$ Robert L. Wiegel, "Waikiki Beach, Oahu, Hawaii: History of Its Transformation from a Natural to an Urban Shore," Shore and Beach 76 (Spring 2008), 3.

${ }^{31}$ Andrea Feeser and Gaye Chan, Waikiki: A History of Forgetting and Remembering (University of Hawaii Press, 2007), 65.

${ }^{32}$ Feeser and Chan, 66.
} 
The land surrounding the Royal Palm Garden, comprising much of the modern Waikiki district found use as agricultural homesteads for local Asian and Native Hawaiian families. Former sugar cane and pineapple plantation workers of Chinese and Japanese decent moved into Waikiki starting in the 1870s, bringing with them wetland agriculture techniques. They grew rice and taro in flood-irrigated field, and raised fish and ducks in large stone walled ponds. Longtime Kalia resident, Ella Wong recalled her family home on Hobron Lane which sat against the future concourse of the Ala Wai Canal. On the two-plus acre property, the family raised mullet, awa (milkfish), and o'opu (stream goby). Wong recalled that the heavy storm floods would bring o'opu from the nearby mountains. She and other local children loved to catch the $o^{6}$ opu that would get swept into the ponds, recalling “They were good eating but funny-looking fish. They were ugly...We had a little rowboat, and we used to go in there and row around that pond. Sometimes we would take our little nets and go fishing.”33 The lowlands of Waikiki lent themselves to aquaculture, but the periodic flooding made life for Waikiki residents challenging. Wong recalled the felled kiawe trees strewn across her property and the chicken coop that had toppled into the fish pond after one particular storm. ${ }^{34}$ The sandy, easily-saturated soil of the district presented issues for residents. On one hand necessary for wetland agriculture, the constant drainage and sweeping silt from higher elevations hindered construction. Other than the fish pond, which predated the Wong family's residence on the premises, Ella recalled her father developed the land very little, stating that he "put up some duplexes that he rented out." ${ }^{35}$ At that time, Native

\footnotetext{
${ }^{33}$ Ella Lila Wong. 1826.

34 Ibid.

${ }^{35}$ Ella Lila Wong, 1819.
} 
Hawaiians comprised the majority of residents in Wong's Hobron Lane neighborhood, living in semi-permanent camps. "They just built houses and moved in, old shacks, all old shacks,” Wong recalled. ${ }^{36}$ The majority of the neighborhood's residents did not own property as the Wongs did. Instead, they built squatter 'camps' on undesirable lands. At the turn of the twentieth century, Honolulu's cultural elites began to recognize the region's potential as a resort district. Hotel development and the subsequent reclamation effort would forever reshape the livelihoods of Waikiki’s poorest residents.

Before Waikiki could begin its transformation from quiet rural wetlands to premium resort locale for the wealthy, the land had to be reshaped to this purpose. The 'spouting waters' of Waikiki rendered its soils saturated and prone to flooding. The streams that fed the Waikiki with fresh water also carried silt and alluvium from the nearby mountains into the wetlands and out to the sea. The first decades of the twentieth century brought increased development to the area, which interrupted the natural processes of erosion and water flow. The construction of Kalakaua Avenue and the first Waikiki resorts, including the Moana and the Seaside between 1901 and 1906, resulted in the disruption of natural drainage of freshwater to the ocean. ${ }^{37}$ As a result, the streams that fed Waikiki became stagnant and filled with silt. The muck that filled the wetlands surrounding the first Waikiki resorts fomented unsanitary conditions. In 1913, the seepage of fetid water reached the shores of the Moana Hotel, sparking tourists' disgust and protest. According to an account in the Pacific Commercial Advertiser, one resort patron demanded, "something be done to prevent a future display of river sweepings in

\footnotetext{
${ }^{36}$ Ella Lila Wong, 1823.

${ }^{37}$ Wiegel, 6.
} 
what has been advertised as one of the most romantic and perfect tempered bathing places in the world." ${ }^{38}$ That something came in the form of the dredging of the Ala Wai Canal in 1921.

The legislative impetus for the Ala Wai Canal formed out of racialized motivations to dispossess Native Hawaiian and local Asian residents from their land. The 1896 Republic of Hawaii Legislature Act 61 contained the legal origins of the reclamation effort. A property act "to Provide for the Improvement of Land in the District of Honolulu deleterious to Public Health, and for the Creation and Foreclosure of Liens to Secure the Payment of the Expense so Incurred,” Act 61 empowered the Board of Health to declare any land parcel within city limits unsanitary, forcing the owner to make improvements as his own expense. ${ }^{39}$ If the owner could not afford to make the prescribed improvements, the government would place a lien on the property for sale to the highest bidder at auction. In this way, the Board of Health targeted disadvantaged ethnic groups for removal from Waikiki, while providing white elites with the means to acquire the ceded lands. However, it would take another decade, and the inclusion and further elaboration of Act 61 within the new Territory of Hawaii’s founding charter before policymakers attempted to invoke the law.

38 "Sluiced Lagoon Water into Waikiki Water and Drove Fair Bathers Away," The Pacific Commercial Advertiser. February 16, 1913, 9. Chronicling America: Historic American Newspapers. Lib. of Congress.

${ }^{39}$ Laws of the Republic of Hawaii Passed by the Legislature at its Session,1896 (Honolulu: Hawaiian Gazette Company, 1896), 201. 
Upon annexation to the United States, Act 61 entered the statutory Revised Laws of Hawaii as Chapter 83 pertaining to the "Sanitary Condition of Land." ${ }^{* 0}$ Chapter 83 opened with section 1025 on "Insanitary conditions to be reported," stating:

Whenever in the opinion of the Board of Health any tract or parcel of land situated in the District of Honolulu, Island of Oahu, shall be deleterious to the public health in consequence of being low, and at times covered or partly covered by water, or of being improperly drained, or incapable by reasonable expenditure of effectual drainage, or for other reason in an unsanitary or dangerous condition, it shall be the duty of the Board of Health to report such fact to the Superintendent of Public Works together with a brief recommendation of the operation deemed advisable to improve such land. ${ }^{41}$

The white elite policymakers of Hawaii used medicalized language to affect the removal of Native Hawaiian and Asian residents from the district without using overt racial terms. Under the auspices of serving public health, the Territorial government exercised control over Waikiki's residents by targeting their the bodies and wellbeing. ${ }^{42}$ The inclusion of Chapter 83 into law demonstrated the territorial government's desire enact an agenda to cleanse the land of both its natural tendency towards flooding and of its less affluent inhabitants. The dominant narrative's reasoning for the "sanitary” clearing of Waikiki even permeated the residents' own historical memory of the event. One resident stated, "I think they built that canal because the swamp was bad. Terrible." ${ }^{43}$ Continuing on the subject, she remarked that visitors not used to the odor complained of the stench that emanated from the stream that ran alongside her house. She concluded that the dredging

\footnotetext{
${ }^{40}$ Revised Laws of Hawaii, 1905, 455.

${ }^{41}$ Ibid.

${ }^{42}$ Michel Foucault, The History of Sexuality. Vol. I: An Introduction. Trans. by Robert Hurley.
} (New York: Random House, 1978), 140.

${ }^{43}$ Mary Ellen Kealohapauole Clarke, oral history interview with Warren Nishimoto, May 20, 1985, Kailua-Kona, Hawai'i. In Waikiki, 1900-1985: Oral Histories Vol. 1 (Honolulu: Center for Oral History, Social Science Research Institute, University of Hawai ‘i, Manoa, 1986), 652. 
of the canal alleviated the complaints, leaving the land "Very improved." ${ }^{44}$ It would not take long from the 1905 inclusion of Chapter 83 for politicians to invoke the law in their plans to reshape the shoreline. In 1906, Lucius E. Pinkham as President of the Territorial Board of Health unveiled his plan to enact the reclamation of Waikiki in accordance with Chapter 83. His efforts, alongside those of his friend and business associate, Walter F. Dillingham, resulted in the construction of the Ala Wai Canal.

The political ambitions of Lucius Eugene Pinkham helped generate the the necessary legal pathways for the reclamation of Waikiki. On February 21, 1906, Pinkham, then the President of the Board of Health, announced his plan, stating that the wetlands were "incapable of drainage" and "in an unsanitary and dangerous condition.” 45 In his report, Reclamation of the Waikiki District, Pinkham echoed the language of Chapter 83 in a clear application of the law. ${ }^{46}$ Outlining his intent to clear the land in the name of public health, the document stated:

The President of the Board of Health recommends that the Government, by its right of eminent domain, shall in an equitable and just manner acquire such ownership and rights in said district as shall enable it to transform it into an absolutely sanitary, beautiful and unique district. One that will add immensely to the reputation of Honolulu at home and abroad. ${ }^{47}$

Pinkham revealed his true plan to reshape Waikiki into tourist destination known the world over. Claiming it impossible for private owners to afford the changes to the land that would improve its sanitation, Pinkham saw acquisition by the state as the only

\footnotetext{
${ }^{44}$ Mary Ellen Kealohapauole Clarke, 653.

45 “Pinkham Plans the Reclamation of All Waikiki,” Evening Bulletin. February 21, 1906, 1. Chronicling America: Historic American Newspapers. Lib. of Congress.

${ }^{46}$ Lucius E. Pinkham, Reclamation of the Waikiki district of the city of Honolulu, Territory of Hawaii: Recommendations, maps, plans and specifications (Honolulu: Hawaiian Gazette, 1906), 3.

${ }^{47}$ Pinkahm, 4.
} 
legitimate option. Pinkham's project involved as much social engineering as it did civil. Citing Southern Californian cities such as Los Angeles as an example, Pinkham saw the opportunity to repopulate the reclaimed district with "Persons and residents of private fortune, who seek an agreeable climate and surroundings, and who expend large already acquired incomes rather than those who expect the community to furnish them the opportunity of earning a livelihood and even that of the accumulation of wealth.”48 If Pinkham had not made clear enough his disdain and prejudice for the incumbent residents of Waikiki, he continued, "Such persons as we seek desire to find attractive and charming residential districts free from all objectionable features and neighbors." ${ }^{49}$ Pinkham saw the Native Hawaiian and Asian agriculturalists on the land as obstacles to his higher purpose. Again, he saw hygiene as the primary discriminant between the constructed binaries of highland and low, rich and poor, worthy and unworthy, and most damningly white and nonwhite. The physical reordering of the space from naturally-fed floodplains to modern cityscape required first the displacement of the unworthy. Finding the backwardness of agrarian life in Waikiki tolerable no longer, Pinkham's plan included the introduction of a grid pattern to the district that could incorporate building sites for real property. Of the redevelopment, Pinkham stated, "In making my plan, I merely suggested to [the City Surveyor] that we put in streets, connecting up the roads, and this was done, but without the idea that the plan as drawn was an arbitrary one. I believe the land could be sold, perhaps to newcomers. Anyway, it is going to be a go."50 With that,

\footnotetext{
${ }^{48}$ Pinkham, 7.

${ }^{49}$ Ibid.

50 "Pinkham Plan to Reclaim Waikiki to be Tried," The Pacific Commercial Advertiser. March 16, 1906, 5. Chronicling America: Historic American Newspapers. Lib. of Congress.
} 
Pinkham revealed his true intention for Waikiki to shed its provincial status as a reminder of Oahu's agrarian past. The inception of the Ala Wai Canal allowed for the incorporation of Waikiki into the modern city of Honolulu as its premier resort district.

\section{2. "Squattersville"}

Pinkham's plan marked the continued persecution of the ethnic poor within city limits. The dredging of the Ala Wai Canal served as only a single example of the forced displacement of Native Hawaiian communities carried out in the name of public health. An April 14, 1914 article in the Hawaiian Gazette described the burning of a squatter settlement on Sand Island, Honolulu Harbor, just two miles from Waikiki. ${ }^{51}$ In this case, territorial and federal health officials removed "between fifty and sixty Hawaiians, Porto Ricans (sic.), and Filipinos” from their homes by night, setting fire to their shelters in the early morning hours. ${ }^{52}$ Interviewed quarantine officer Captain F.E. Trotter explained that such makeshift colonies presented a "nuisance to the health of the community, and moreover was a rendezvous for undesirables." 53 Such actions highlighted the contemporary discursive imagining of Hawaiians as unclean and prone to criminality. Actions set forth by the state during the Republican and early Territorial periods pushed Native Hawaiian and other nonwhite poor to the vertices of society. Squatter camps, such as the ones in Honolulu Harbor, Ala Moana, and Waikiki all developed on unused land parcels at or below sea level along the coastline. Chapter 83 of the Revised Laws of Hawaii aimed to remove so-labelled “undesirables” from even these tracts by means of

\footnotetext{
51 “Officers Burn Squatters’ Huts,” Hawaiian Gazette. April 14, 1914, 1.

${ }^{52}$ Ibid.

${ }^{53}$ Ibid.
} 
reclamation and redevelopment. Following the closure of the Sand Island settlement in 1914, Waikiki residents, particularly in the Hobron Lane and Kalia neighborhoods recalled an influx of Native Hawaiians to the area. Ella Lila Wong and other community members recounted their amicable interactions with the Native Hawaiians who peopled the "Squattersville" settlement in Waikiki.

Removed from other areas of Honolulu, the city's population of transient poor settled in Waikiki’s “Squattersville.” Geographically bound by the Kalia and Pi'inaio streams, Hobron Lane, Makanoe Lane, and John ‘Ena Road comprised Squattersville’s main thoroughfares. ${ }^{54}$ Native Hawaiian Kalia resident “Tootsie” Steer recalled that the city had purchased the tracts of land surround her parents' estate, allowing poor residents to move in, thus creating Waikiki's Squattersville. ${ }^{55}$ The move to purchase land and establish a Squattersville in Waikiki accompanied the city’s desire to close a similar Squattersville in nearby Ala Moana that had been built on the site of the city dump and quarantine station. Of the event, Steer recalled:

Then I forgot what year this was, but it was before the year 1930. Way before the year, 1930. You know, the squatters, the old Hawaiians used to, like the beach people now, live on the Ala Moana, the old dumping place...Well, these people who had no homes, Hawaiian people, that's where they lived. They built their homes there on the dumps. Then, we called them Squattersville. Then, they moved from there to where the Ala Wai comes to Kalakaua Avenue. Well, that land from there to John 'Ena Road, all the way down to Hobron Lane, in there, that was the next Squattersville.

The city took them off of there [Ala Moana], and put them there. But there were people that (already) lived there that had homes. Right along Kalakaua Avenue. I know these friends of ours had this big house on [the future site of the] Ala Wai [Canal]. Big, big house and the yard. I think he eventually had to sell

${ }^{54}$ Ella Lila Wong, 1823; Adelaide Mckinzie, oral history interview with Warren Nishimoto, April 23, 1986, Ala Moana, O'ahu. In Waikiki, 1900-1985: Oral Histories Vol. 1 (Honolulu: Center for Oral History, Social Science Research Institute, University of Hawai 'i, Manoa, 1986), 1183.

${ }^{55}$ Doveline "Tootsie” Notley Steer, oral history interview with 'Iwilani Hodges, April 1, 1985, Kailua, O‘ahu. In Waikiki, 1900-1985: Oral Histories Vol. 1 (Honolulu: Center for Oral History, Social Science Research Institute, University of Hawai'i, Manoa, 1986), 1599. 
because the city wanted to buy that whole place. I had lot of friends that lived in there. They had to sell to make Squattersville.

As part of the City and Territorial governments' efforts to contain the settlement of poorer nonwhite residents, Squattersville provided temporary sanctuary for Honolulu’s "undesirables.” Far from the feared criminal elements that officials such as Capt. Trotter described, the families of Squattersville made good impressions on their neighbors. Mary Clarke, née Paoa, recalled that her parents had a few close friends from the Squattersville community. Always giving, Clarke recalled that, "They used to bring fish or whatever they had to us. But my father hardly took it because he went fishing, he told me. But they'd bring breadfruit, they (always brought) something." ${ }^{56}$ Gift giving in the form of small tokens, often food, formed the basis of good manners and community building in Hawaiian culture. Waikiki residents regarded their neighbors as extended family.

Adelaide McKinzie remembered spending summers at the Paoa house with her cousins Mary Clarke and Fred Paoa. She recalled "Kalia had (a) lot of children...(there) were about six of us in the Paoa household. Then the Harbottles had about four (and) the next house, the Kahales had two. And we'd all gang together." ${ }^{57}$ McKinzie noted that the neighborhood raised the children together, making little distinction between their own and their neighbors'. Communal caretaking and generosity extended across class levels with the children of squatters, middle-class families, and upper-class families, such as the Paoa's, all receiving care equally. Responsibility for child care even extended up to the stations of royalty. McKinzie stated that when the children would swim out to the

\footnotetext{
${ }^{56}$ Mary Clarke, 653.

${ }^{57}$ Adelaide McKinzie, 1177.
} 
Kapahulu side of Waikiki, they received milk and cookies as refreshments from Princess Elizabeth Kahanu Kalaniana'ole, consort to royal family patriarch and U.S. congressman Prince Kuhio. ${ }^{58}$ The princess doted on Waikiki's children because "the neighborhood kids would be Hawaiians, part-Hawaiians, Japanese, Chinese, all mixed, Portuguese, chop suey bunch of kids." ${ }^{59}$ The princess’s kindness stemmed from Hawaiian cultural concern for the community. The congenial atmosphere and communal concern challenged racialized hegemonic views of Hawaiians as unclean and wont to crime. The plan to dredge and reclaim Waikiki therefore revealed the insidious nature of the state, which used its medical authority over the bodies of its citizens to affect social upheaval. The reclamation of Waikiki can only be seen as a power grab by government actors, including Lucius E. Pinkham, to enable their own monetary gain. Enacting Pinkham’s vision for a redeveloped Waikiki required further planning on behalf of private companies and Territorial Legislature before his dream could become reality.

\subsection{Dredging the Ala Wai Canal}

Once planned, initiating the groundwork for the Ala Wai Canal proved challenging. Appointed Territory Governor of Hawaii by President Woodrow Wilson in 1913, Pinkham finally gained the political authority necessary to enact his plan. In pursuant to his goal, Pinkham signed Act 102 of the 1917 Legislature Session, appropriating \$5,000 for the Superintendent of Public Works to produce “a complete survey, map, and plans of all that district in Honolulu between King Street and the sea

\footnotetext{
58 Ibid.

59 Ibid.
} 
beach and between Kapahulu Road and Sheridan Street.”60 The area comprised the entirety of the Waikiki district. Act 102 echoed language from the 1905 Revised Laws of Hawaii in reference to lands found "deleterious to public health." ${ }^{61}$ In this iteration, it fell upon the the Superintendent of Public Works to appraise and evaluate each parcel of land, making note of all owners and occupants present. The act provided the basis for determining land values and stockholders for the eventual acquisition of large tracts of Waikiki through eminent domain. This approach varied from the earlier proposal set forth by the 1896 Republic of Hawaii legislature. Acknowledging that private owners could not afford the extensive improvements prescribed in Pinkham's reclamation plan, legislators made preparations to acquire the lands needed to initiate dredging.

Following the survey of Waikiki, legislative and executive efforts to provision for the region's reclamation picked up steam. On May 4, 1917, the Hawaiian Gazette reported the establishment of a Senate commission to research and determine an engineering plan forward for the reclamation project. ${ }^{62}$ Beginning work in October, the commission determined that a canal " 250 feet wide and 26 feet deep” ${ }^{63}$ will cover an "area extending from Kapi 'olani Park to the sea and the 'Ewa end of said area." 64 The commission called for materials dredged from the canal to provide landfill for the low lying lands, the taro fields and duck ponds, on either side. During a Special Session of the Legislature in May 1918, lawmakers appropriated \$100,000 toward the dredging of a

\footnotetext{
${ }^{60}$ Laws of the Territory of Hawaii passed by the Legislature (Honolulu: Territory of Hawaii Legislature, Act 102, Session Laws, 1917), 142.

${ }^{61}$ Ibid.

62 “Senate Approve Waikiki Commission," Hawaiian Gazette. May 4, 1917, 5.

${ }^{63}$ Senate Journal Ninth Legislature of the Territory of Hawaii, Special Session 1918 (Honolulu: Tongg Publishing Co., 1918), 10.

${ }^{64}$ Laws of the Territory of Hawaii passed by the Legislature, Act 231, Session Laws, 1917, 458.
} 
canal per the commission's recommendations. ${ }^{65}$ As part of this act, Governor Pinkham authorized the Superintendent of Public Works to "enter into a contract or contracts for the excavation of said portion of said lagoon or drainage canal.”66 Having the territory’s only dredging boats, as well as a strong business relationship with Pinkham, it followed Walter Francis Dillingham's Hawaiian Dredging Company received the contract to build the canal.

Walter Francis Dillingham, eldest son of infrastructure magnate Benjamin Dillingham, founded the Hawaiian Dredging Company in 1902. At the turn of the twentieth century, Benjamin Dillingham’s Oahu Railway and Land Company held contracts to key infrastructure and development projects, including the dredging of Honolulu Harbor. ${ }^{67}$ Against his father's advice, Walter purchased the company's dredge upon the completion of the harbor project to form his own spin-off venture. The Hawaiian Dredging Company worked on all of Honolulu's shoreline developments dating back to this period, including the dredging of Kewalo Basin, the re-dredging of Honolulu Harbor, and the construction of its commercial piers. ${ }^{68}$ Pinkham’s association with the Dillingham family began in 1892 when he arrived from San Francisco to supervise the construction of a coal handling plant for the Oahu Rail and Land Company. Appointed Treasurer of Benjamin Dillingham’s Pacific Hardware Company in 1898,

${ }^{65}$ Report of the Superintendent of Public Works to the Governor of the Territory of Hawaii (Honolulu: Paradise of the Pacific Press, 1918), 27.

${ }^{66}$ Laws of the Territory of Hawaii passed by the Legislature (Honolulu: Territory of Hawaii Legislature, Act 14, Session Laws, 1918)

67 “One of Hawaii’s Captains of Finance,” The Pacific Commercial Advertiser. July 19, 1902, 2.

${ }^{68}$ Earl Vida, oral history interview with Warren Nishimoto, March 18, 1985, Wai‘alae, O‘ahu. In Waikiki, 1900-1985: Oral Histories Vol. 1 (Honolulu: Center for Oral History, Social Science Research Institute, University of Hawai‘i, Manoa, 1986), 593. 
Pinkham further solidified his ties to Dillingham-owned enterprises. ${ }^{69}$ Pinkham’s connections to the Dillingham family pointed to the interwoven nature of political and business interests in Hawaii, and how a small number of actors intervened to affect the reshaping of Honolulu against the interests of less wealthy incumbents. Waikiki resident Earl Vida recalled working for the Hawaiian Dredging Company on the Ala Wai Canal project, recounting the immense changes it spelled for his neighbors.

Earl "Liko" Vida, born on October 23, 1901, grew up in the Kalia neighborhood of Waikiki, experiencing first-hand the changes that came with dredging the Ala Wai Canal. Of Spanish, English, and Hawaiian ancestry, his father, Henry Cornwall Vida, worked for the Hawaiian Dredging Company as superintendent for the project. When dredging of the Canal began in 1921, Earl assisted his father as a dredge operator. As a child, he recalled the large ponds that dominated the landscape. Among his earliest memories, he stated, "Now, when we went to school, we'd go up Hobron Lane and go across the duck ponds and into Ka'ahumanu School. That's how we used to walk to school because there [were] no roads in those days. ${ }^{70}$ His childhood memories included riding elevated streetcars over duck ponds to downtown Honolulu, as well as playing baseball on a solid coral field on government land near his house. He remembered the poi factory on Hobron Lane, stating, "The poi factory was near the Kalauokalanis and the Hobron Estate. Right here, where the old stream used to run. Now, this is the poi factory on John 'Ena Road and Hobron Lane, right in here."71 The production of poi, a starchy

\footnotetext{
${ }^{69}$ H. Brent Melendy, “The Controversial Appointment of Lucius Eugene Pinkham, Hawaii’s First Democratic Governor.” The Hawaiian Journal of History, vol. 17 (1983).

${ }^{70}$ Earl Vida, 588.

${ }^{71}$ Ibid.
} 
paste made from baked taro root, required access to copious amounts of water and proximity to flood-irrigated taro fields, making Waikiki an ideal location. In accordance with the desire to repurpose the surrounding land to new economic purposes, and ultimately new hands, haole hotel managers had long bemoaned the prevalence of Native Hawaiian and Asian agriculture in the area. At the turn of the century, resort operator Jim Sherwood issued a complaint to the Hawaiian Star regarding the sanitary threat the Waikiki poi factory posed to public health. In the article, he stated, "The refuse from a Chinese poi factory on Waikiki stream near the sea, is thrown into the sea. It sinks to the bottom and remains there. At low tide it is uncovered and becomes putrid in the hot sun, emitting an unbearable odor." 72 The statement underscored the two competing visions for Waikiki as both an rural environment for agricultural development and as a burgeoning resort locale for the rich. The resort manager's statement revealed racialized sentiments that immediately painted the agricultural use of the land as both foreign and unclean. Earl Vida noted that the development of the Ala Wai Canal displaced the area's taro farmers and poi producers to other parts of the island, recalling:

Well, they moved out to other places. Most of them went to Pearl City because they stil had that pring setup down there. The water still exists there. Taro patches. And also, in addition to that area, they went to Waiahole. That's where Matson had a big piece of land. So, all that's all into taro patch land and banana. Waiahole is very strong in that area for taro. All the farmers that were living in Waikiki and Kalia who were utilizing the water area for their profession moved to that area. ${ }^{73}$

The dredging effort in Waikiki diverted the water and filled in lower lying lands that taro farmers in the area depended on for their subsistence. The dispossession of Native

\footnotetext{
72 “Dangerous to Health,” Hawaiian Star. April 25, 1898, 1.

${ }^{73}$ Earl Vida, 596.
} 
Hawaiian and Asian farmers from the once-fertile lands of Waikiki marked the culmination of attempts on behalf of the territorial government and the haole elite to redefine Waikiki as a space for tourist development. Using racialized and medicalized rhetoric, actors representing the government and private business, such as Lucius Pinkham and Walter Dillingham, affected the cleansing of Waikiki in their own image. Where they saw an unclean and underutilized landscape harboring both society's undesirables and disease, Pinkham and Dillingham reimagined through use of law and force. With the central Kalia section of Waikiki razed and ready for the onset of a new class of arrivals and their subsequent desires, the outlying areas, such as the Hamohamo neighborhood where old Hawaiian families resided alongside newer Japanese incumbents, underwent their own social reconstruction as a result.

From racially-motivated political theory that invoked public health as its impetus, to the realized destruction of local farmers' livelihoods, the dredging of the Ala Wai Canal spelled momentous change for Waikiki and its residents. The recollections of Ella Wong and Adelaide McKinzie shared a rural vision of Waikiki as home to Native Hawaiian and local Asian farmers who planted taro fields and kept duck ponds as their primary mode of subsistence. The actions of Lucius Eugene Pinkham as President of the Board of Health and then Governor of the Territory revealed the political desires of the haole elite to transform the district into a landscape for profit and leisure at the expense of the incumbent residents of Waikiki. Legislative records charted the progress of Pinkham's dream, providing the legal mechanisms necessary to enact his plan through the auspices of providing for the public health. Deeming the land as cultivated by the local farmers miasmic and "deleterious to the public health," the territorial government 
allowed for the seizure of land and property in Waikiki to affect the construction of drainage canal that would allow for the reclamation of the low lying lands in the district. Walter F. Dillingham's Hawaiian Dredging Company set the groundwork for the construction of what became the Ala Wai Canal. Dredge operator Earl Vida recalled the destruction of taro farms and livelihoods as dredging boats moved through the natural stream, widening the canal, and depositing the remains along its shores. The displaced farmers radiated out of Honolulu to outlying areas of Oahu so that they might continue a similar way of life. 


\section{CHAPTER THREE: JAPANESE IMMIGRATION AND AMALGAMATION}

We arrived on June 8, 1914 at the immigration office. It happened that the ship prior to ours had some kind of bad illness on it. They were busy with the people with this illness, so the procedures for [the passengers] of our ship took some time. So we were detained at the immigration office for two days. On the tenth of June, we came out. We arrived there on the tenth.

Hamohamo resident Miyo Asuka, 91, retired laundress

The notion of a nascent Pacific Age seized the imagination of economists, politicians, and naval authorities on both sides of the Pacific at the close of the nineteenth century. The lofty concerns of such men as Inagaki Manjiro, Kaneko Kentaro, Alfred Thayer Mahan, and Theodore Roosevelt theorized the Pacific Ocean as the future locus of the global struggle for dominance. ${ }^{74}$ With large reservoirs of resources and labor not yet under the control of the competing imperialist powers, the Pacific appeared ripe for conquest to ambitious naval policymakers. However, the aforementioned view of the vast ocean basin lacked the objective understanding that while navies facilitated the flow of goods and personnel over maritime distances, individual desire for a better life, and the advertised opportunity to seek it, shaped cultural and biological interexchange within communities connected by a common sea. By this view, both political power and individual action worked to shape the Pacific into a multicultural, international domain. While oceanic communities lent themselves to culturally diverse and hybridized populations, national and racial politics played prevalent roles in the continued division, tension, and inequality between peoples throughout the Pacific. Through the analysis of the oral accounts of issei, or first-generation, Japanese immigrants who settled the

\footnotetext{
${ }^{74}$ Pekka Korhonen, “The Pacific Age in World History.” Journal of World History 18, no. 1
} (Spring, 1996), 41. 
Waikiki area in the early twentieth century alongside official U.S. documents and other written articles produced by local and mainland white anti-immigration dissidents, this chapter reconstructs the journey of ambitious Japanese new arrivals to Hawaii. From arrivals as contact labor for sugarcane and pineapple plantations to the establishment of successful businesses in Waikiki, Japanese arrivals to Hawaii shaped local culture against adversity from racist, anti-Asian immigration sentiments held by territorial and U.S. policymakers and industrialists.

The chapter follows the stories of Hamohamo Japanese residents Miyo Asuka, Toshio Yasumatsu, Helen Kusunoki, and others. I intertwine their narratives with contextual evidence of anti-Japanese policies that capture unabashed racialized intentions describing the Japanese new arrivals as first a necessary and beneficial reserve of nonwhite, unskilled labor, later devolving into nativist, populist rhetoric against the influx of a feared and perceived inferior people. The chapter opens with a consideration of the oceanic passage between Japan and Hawaii made by all new arrivals. Personal accounts revealed recollections of the journey, and experiences of integrating into an existing multiracial working class. Official Labor Department documents and local newspaper articles exposed a racialized description of Japanese immigrants and the white ruling class's hopes and expectations for the new class developing within Hawaiian society. As Japanese immigrants moved into urban lifestyles and occupations, they faced new challenges gaining acceptance by their communities while competing with white, skilled laborers for jobs. Within Hamohamo, a unique image of day-to-day life for Japanese hotel and laundry workers developed through the accounts of Miyo Asuka, who together with her husband operated a housing camp for Japanese working-class families. 
Captured within stories of Japanese comingling with other ethnic nonwhites through shared activities and the practice of talking story, a narrative of everyday resistance to cultural colonization arose. Consistent with James C. Scott's notion of "everyday resistance” to hegemonic influences, the bonds produced between Japanese immigrants and other members of the multiracial working class in Hamohamo provided an outlet for shared experiences of adversity. ${ }^{75}$ With opportunities to express commonalities between Japanese and other nonwhite neighbors established, mutual understanding through cultural outreach developed. Social organizations such as the Waikiki Aloha Kai organized community events designed both to maintain and strengthen connections between Japanese diaspora in Hawaii as well as promote Japanese culture in an open, approachable way to the broader Hawaiian community-at-large. The evidence presented opposes then-contemporary discourse of "yellow peril" and ethno-nationalism that excluded Asian Americans from citizenship and equal rights under the law.

The chapter closes with a consideration of the prevalence of Japanese-owned businesses in Hamohamo, with particular attention given to Japanese commerce organizations in Honolulu that arose to protect the interests of their constituents against anti-Asian immigrant legislation at home and throughout the United States. In common with Japanese social organizations in the neighborhood, Japanese business owners promoted improved cultural understanding between Japanese residents and the rest of the community. Through the integration of Hawaiian food staples and positive interaction with customers and neighbors, Japanese-owned business owners gained acceptance within their communities in ways that defied political rhetoric from the local haole elite

\footnotetext{
${ }^{75}$ James C. Scott, Weapons of the Weak, 37.
} 
and mainland U.S. policymakers. Consistent with the theme of resistance and integration, a look into the ad hoc money lending system called tanomoshi revealed an undercurrent of distrust of the official capitalist banking system organized by the haole elite. For their part, territorial lawmakers and the press took aim at the tanomoshi system as insidious and predatory in nature against the interests of the loan takers who would default on their loans. Examination of territorial law revealed an intent to outlaw nontraditional lending systems in order to restrict access to credit to individuals who qualified under the official banking system in place. Through the investigation of Japanese arrivals to Hawaii from their initial immigration as contract laborers to their successful integration into urban communities in Waikiki, personal accounts revealed the development of a multiracial working class in Waikiki that resisted cultural colonization through improved understanding and mutual support.

\subsection{Japanese Immigration to Hawaii}

Increased maritime involvement in the Pacific on the part of European powers in the latter nineteenth century incited a climate of optimism for future commercial and military expansion on both sides of the Pacific. Japanese political economist Inagaki Manjiro proclaimed in his 1890 English-language treatise, Japan and the Pacific and the Japanese View of the Eastern Question, "Without doubt the Pacific will in the coming century be the platform of commercial and political enterprise. This truth, however, escapes the eyes of ninety-nine out of a hundred, just as did the importance of Eastern 
Europe in 1790 and Central Asia in 1857." ${ }^{76}$ Comparing the situation in the Pacific to multivalent, large-scale moments of political and military strife, such as the Crimean War, Inagaki foresaw the Pacific as the nexus of global development in the twentieth century, calling the period Taiheiyō jidai, or the Pacific Age. The optimism espoused by the Meiji era economic theorist belied Japan's ambitions to emerge from three hundred years of isolation as a modern nation-state with imperialist ambitions on par with those of the Western powers that opened the island nation to the world by force. On the opposite side of the ocean basin, American naval Captain Alfred Thayer Mahan aimed to focus the United States' political and economic attention to the Pacific. He viewed the ocean and its resources not as a landscape of plenty, as did Inagaki, but one of scarcity that required military power to secure. In his most consequential work, The Influence of Sea Power upon History, 1660-1783, Mahan preached the modernization of the U.S. Navy as the route to American dominance and exceptionalism in world politics. ${ }^{77}$ In the decades bookending the turn of the twentieth century, both nations set their policy aims into practice with the United States’ annexation of the Philippines, Guam, and Hawaii in 1898 and Japan’s success in the Russo-Japanese War in 1905. Both nations' extended presence and dominance in the Pacific set a course for further conflict between the two. Fear of Japanese expansion at the hands of Western defeat, as demonstrated by the former's decisive victory against the Russian Empire, incited racialized depictions of “yellow peril” within American discourse. ${ }^{78}$ Jack London’s eponymously titled essay,

${ }^{76}$ Inagaki Manjiro, Japan and the Pacific and the Japanese View of the Eastern Question. (London: Scribner and Welford, 1890), 21-22.

${ }^{77}$ Alfred Thayer Mahan, The Influence of Sea Power upon History, 1660-1783 (London: Sampson, Low, Marston, 1890).

${ }^{78}$ Korhonen, 50. 
“The Yellow Peril,” introduced the term to American audiences. ${ }^{79}$ Describing an emergent "great race adventure" in the Pacific, London echoed the same refrain for increased resource acquisition in the Pacific as Inagaki and Mahan, however this time framing the impending struggle as a matter of racial prestige. In Hawaii, where relations between the Japanese and local government started prior to U.S. annexation, notions of "yellow peril” spelled abrupt changes in relations between the two.

Diplomatic negotiations between the Kingdom of Hawaii and the Empire of Japan yielded the Kanyaku Imin immigration system that brought rural Japanese laborers to Hawaii as contract workers for sugarcane and pineapple plantations. Under Kanyaku Imin, 29,339 Japanese nationals arrived in Hawaii during the treaty period between 1885 to $1894 .^{80}$ The need for labor in Hawaii arose from industrial demands for a new unskilled labor force to fuel sugarcane and pineapple plantation growth against a backdrop of a declining Native Hawaiian population. A 1902 Report from the U.S. Commissioner of Labor cited the historic need for exogenous labor with the following statement:

While the Hawaiians as individuals are marked by superior physique and bodily vigor, the race as a whole is decadent in contact with modern civilization. The natives have decreased in numbers from 70,000 to 30,000 in the last half century. So rapid has been the wasting away of the indigenous population that it early excited the alarm the Government and threatened to cause serious economic disturbances in the kingdom. ${ }^{81}$

\footnotetext{
79 Jack London, “The Yellow Peril,” in Revolution and Other Essays (London: Mill and Boon, 1910), 220-237.

${ }^{80}$ Report of the Commissioner of Labor on Hawaii, 1902, (Washington: Government Printing Office, 1903), 36.

${ }^{81}$ Report of the Commissioner of Labor on Hawaii, 1902, 20.
} 
The report captured the racialized priorities of agriculture industry leaders to find an expedient solution to the the loss one nonwhite labor population by replacing it with another. While laboring populations did arrive from Portugal, Madeira, and the Azores, Hawaiian government officials and industrialists focused their recruitment efforts on Asia. By design, the Kanyaku Imin agreement restricted emigration and recruitment to rural communities in Hiroshima and Yamaguchi Prefectures, selected for their high incidence of farm workers who both governments' officials agreed had the skills and temperament necessary for success of plantation labor. ${ }^{82}$ The February 8, 1885 arrival of the first Japanese immigrant laborers to Honolulu Harbor aboard the S.S. City of Tokio led to curiosity on behalf of both the local population and the press. The Daily Bulletin remarked, “This morning the Immigration Depot presents an unusually lively scene and illustrates Japanese life. All appear to be well satisfied with their quarters, they are very quiet and peaceable, and a better looking lot of immigrants, as a whole, has never arrived on these shores before.” ${ }^{83}$ Already a reductionist view of Japanese people as obedient, respectful, and willing to receive direction from white superiors arose in the narration of their first arrival. The Pacific Commercial Advertiser shared the Bulletin's enthusiasm, noting not only the apparent health and happiness of the new arrivals, but giving high praise to Minister to Japan, Robert Walker Irwin, stating, "Mr. Irwin is to be congratulated upon having having brought to these shores so fine a body of desirable immigrants, and the Government may well be proud of their success in having so happily inaugurated an immigration that...cannot fail of being great benefit to the country." 84

\footnotetext{
${ }^{82}$ Ibid.

83 “The Japanese Immigrants,” Daily Bulletin. February 9, 1885, 2.

84 “The City of Tokio,” Pacific Commerical Advertiser. February 9, 1885, 2.
} 
The importation of bodies fit to do labor and thus provide economic growth to the Kingdom seemed the paramount concern of both the government and industry. Both newspapers, the Advertiser and the Bulletin provided pro-industry commentary on the issue in line with the viewpoints of their mainly white, English-speaking audience. As Japanese immigration continued into the twentieth century, official and editorial opinions on the once government-backed project shifted to reflect contemporary racial discourse in reaction to the shifting demographics of Hawaii.

By the turn of the twentieth century, people of Japanese descent formed a plurality of Hawaii's population, inciting fear of social dominance amongst the haole elite. According to the 1900 United States Census, the Japanese population in Hawaii numbered 61,115, comprising 39.69\% of the total population. The Hawaii-born Caucasian population at that time numbered 7,283, comprising $4.73 \%$ of the Territory's population. ${ }^{85}$ The increasing number of Japanese residents in Hawaii occurred during a period of concern over declining birthrates amongst Anglo-Americans on the U.S. mainland resulting in demographic shift. President Theodore Roosevelt injected nationalist and pronatalist rhetoric into such discussions, labelling the perceived devaluation of raising a family amongst white American couples "race suicide." 86 The President's first use of the phrase appeared in his 1902 letter to Bessie Van Vorst in response to her article in Everybody’s Magazine, titled “The Woman Who Toils.” 87 The article itself depicted the world of women wage earners, unearthing two main groups of

85 Thos. G. Thrum, Hawaiian Almanac and Annual for 1904. (Honolulu: Thos. G. Thrum Company, 1903), 18-19.

${ }^{86}$ Albert Loren Cheney, Personal Memoirs of the Home Life of the late Theodore Roosevelt. (Washington: The Cheney Publishing Company, 1919), 132.

${ }^{87}$ Ibid. 
workers: working class women who worked out of necessity and a smaller group of wellto-do women who worked to earn leisure money for personal consumption. ${ }^{88}$ Roosevelt took objection to the notion of women working outside of the home, seeing the practice as a distraction from their civic duty of raising a family. In his stern response to Van Vort, Roosevelt stated:

If a man or woman, through no fault of his or hers, goes throughout life denied those highest of all joys which spring only from home life, from the having and bringing up of many healthy children, I feel for them deep and respectful sympathy — the sympathy one extends to the gallant fellow killed at the beginning of a campaign, or the man who toils hard and is brought to ruin by the fault of others. But the man or woman who deliberately avoids marriage, and has a heart so cold as to know no passion and a brain so shallow and selfish as to dislike having children, is in effect a criminal against the race, and should be an object of contemptuous abhorrence by all healthy people. ${ }^{89}$

Veiling his sexism with racism, Roosevelt noted duty to race as his primary objection to white women in the workplace. The President supported notions of family building as a counter to increasing immigration from less desirable, non-Anglo groups. The collection and availability of census data helped perpetuate fears of social takeover by large immigrant groups. In result, pronatalist sentiments developed as a means of ensuring the continuance of racial dominance in the face of competition from new arrivals. Viewing population as a statistical figure to manipulate, policymakers and journalists pointed to rising non-Anglo figures as a sign of social degradation. In Hawaii, the emergent Japanese population, fueled by coercive recruiting practices on the part of plantation officials, instilled fear and concern within the haole elite over future control of society.

${ }^{88}$ Bessie Van Vort and Marie Van Vort, The Woman Who Toils: Being the Experiences of Two Gentlewomen as Factory Girls. (New York: Doubleday, Page \& Company, 1903). Collection of Van Vort's articles in Everybody's Magazine, published between September, 1902 and January, 1903.

${ }^{89}$ Albert Loren Cheney, Personal Memoirs of the Home Life of the Late Theodore Roosevelt. (Washington: The Cheney Publishing Company, 1919), 132. 
Concern over competition for skilled and unskilled labor positions permeated print accounts of Japanese immigration. In 1903, U.S. Commissioner General of Immigration Francis P. Sargent assessed the immigrant labor situation in Hawaii at the invitation of the territorial government. Listening to the concerns of local politician, businessmen, and white laborers, Sargent announced upon his departure that he would devise a plan to assuage their fears, stating “The laboring people have said that the Japanese immigration is an evil, for, instead of remaining on the plantations, the Japanese flock to the cities and invade all classes of labor, and drive out the skilled white labor. In fact, the statement has been made that large numbers of white laborers have been forced to leave this islands on this account." ${ }^{90}$ Akin to other unfree labor situations utilized by the railroad and coal mining industries of in the North American West, Hawaiian plantation owners attracted Asian laborers through the implementation of labor contracts. Plantation recruiters visited villages surrounding port cities in China and Japan to attract teams of young men who together would form a hui, or "company," responsible for the delivery of a specified amount of sugarcane or pineapple over the lifetime of the contract. The corporation, or "Mill," promised to provide passage to Hawaii, land acreage for the hui to farm, housing provisions, and monthly cash advances with interest assessed in exchange for labor provided. ${ }^{91}$ The terms of the contract set harsh conditions on the plantation worker, leaving little room for profit by its conclusion. However, upon the successful completion of a contract, the members of the former hui had the freedom to leave the plantation and pursue alternate forms of work. Accounts of Japanese contract

90 "What Sargent Had to Say,” The Hawaiian Star. May 20, 1903, 5.

${ }^{91}$ Report of the Commissioner of Labor on Hawaii, 1902, 60-63. 
labor and immigration to Hawaii and the United States mainland matched experiences common throughout the Western Pacific and Europe as part of a cat-and-mouse game between the U.S. government and large recruiting companies to stem the practice of contract labor.

The scarcity of labor in Hawaii and the Eastern Pacific prompted coercive and unfair recruiting practices in coastal communities in Asia, Europe, and the Americas. As seen with the arrival of Hawaii's first Japanese immigrants aboard the Pacific Mail Steamship Company's S.S. City of Tokio in 1885, the steamship companies that ferried immigrant passengers to their new livelihoods often operated as recruitment agencies, collecting a fee from plantations and mining companies for the laborers they transported. ${ }^{92}$ Taking advantage of laborers' desire to seek better paying opportunities abroad, as well as their inability to afford passage across the ocean, steamship officials convinced groups of young men and women to sign hui contracts. In 1885, U.S. Congress passed the Alien Contract Labor Act designed to discontinue the practice of importing inexpensive, unfree labor. Rather than objecting to the dehumanizing conditions through which contract laborers suffered, proponents of the law complained that the low wages such workers accepted devalued unskilled white labor. ${ }^{93}$ California State Senator Phillip A. Roach seized on this sentiment to an audience at an IrishAmerican hall, believing Chinese and Japanese laborers to represent "the surplus and inferior population of Asia." ${ }^{94}$ Speaking to workers who competed with contract

\footnotetext{
${ }^{92}$ Thomas G. Andrews, Killing for Coal: America's Deadliest Labor War. (Cambridge: Harvard University Press, 2008), 2.

${ }^{93}$ Stacey L. Smith, Freedom's Frontier: California and the Struggle over Unfree Labor, Emancipation, and Reconstruction. (Chapel Hill: University of North Carolina Press, 2013), 82.

94 “Enthusiastic Democrats,” Daily Alta California. October 26, 1884, 1.
} 
laborers, Roach played on racist views to garner their support. His support for the cessation of importing contract laborers stemmed from the depreciating effects it had on wages for unskilled labor.

For the Japanese new arrivals who signed such unfair contracts, the opportunity to earn higher wages than they did under strict Meiji era land and farming reforms provided the impetus for their emigration. Unsuccessful land reforms in 1873 increased the tax burden on farmers who now, as landowners, owed taxes to the central government in place of local landlords. ${ }^{95}$ The Meiji government's harsh policies on taxation and farming extended to the types of crops grown and amount one could plant. Waikiki resident Toshio Yasumatsu recalled the difficulty he had following government farming requirements prior to leaving for Hawaii. On the topic, he stated:

It was a pain in those days--working with the government. These days, government is so simple. Even today, they are still growing tobacco [in Japan] at our hometown because the price is so good, and because it's not difficult. It's easy so they've continued with it. In the old days, it was already decided exactly how much you could plant per unit of area. If you planted even one extra one, they would complain. So we hated growing tobacco because the government was so picky. But farmers didn't have any other income, so they grew tobacco in order to have money for the New Year's. ${ }^{96}$

Difficulty dealing with the government coupled with an aggressive recruiting campaign carried out by steamship companies and plantations contributed to the large number of Japanese laborers leaving their homes for harsh new lives under unfair contracts. The rural Japanese tradition of earning wages as nomadic dekasegi workers, travelling from

\footnotetext{
${ }^{95}$ Jonathan Dresner, “International Labour Migrants’ Return to Meiji-era Yamaguchi and Hiroshima: Economic and Social Effects.” International Migration 46 (2008), 68.

${ }^{96}$ Toshio Yasumatsu, oral history interview with Michi Kodama-Nishimoto, February 26, 1985, Kapahulu, O‘ahu. In Waikiki, 1900-1985: Oral Histories Vol. 1 (Honolulu: Center for Oral History, Social Science Research Institute, University of Hawai'i, Manoa, 1986), 829.
} 
one opportunity to the next and sending earned income back home, added to the cultural acceptance of labor migration.

Japanese dekasegi workers came from impoverished communities to which they provided economic relief through the wages they sent back. The Meiji government crafters of Kanyaku Imin chose to restrict emigration to villages within the Hiroshima and Yamaguchi Prefectures by design. Beyond the political convenience of selecting regions from which government leaders had personal ties, the rural communities chosen suffered from poverty and few employment opportunities. ${ }^{97}$ In her recollections, Miyo Asuka recounted the difficulty she and her husband faced when they decided to move back to Japan, stating:

When we first went back [to Japan] we went back not intending to come back [to Hawaii] after having been here for four years. We went back after our oldest daughter was born. We went back not intending to come back. But after we got there we realized how difficult it was to live in Japan.

My father came to see me off at Hiroshima station. At that time, he told me that if I reached my goal I could go home even tomorrow, but if I didn't reach it, I couldn't go home for the rest of my life. I guess that's why I haven't gone home for the rest of my life. (Laughs) That's what my father said. ${ }^{98}$

Choosing to return yet again to Hawaii in 1920, Miyo Asuka and her husband found gainful employment as landlords of her brother-in-law’s housing camp in the Hamohamo neighborhood of Waikiki. The money they sent home, in conjunction with the sums repatriated by other Japanese laborers in Hawaii, provided for community improvements to the villages they left behind. The remittances sent by Japanese laborers in Hawaii to Oshima Island, Yamaguchi Prefecture reached 158,000 yen for the year 1912 alone,

\footnotetext{
97 Dresner, 72.

${ }^{98}$ Miyo Asuka, 892-893.
} 
rivalling the entire island's economic output. ${ }^{99}$ Remittances from wages earned in Hawaii between 1892 and 1907 equaled 1.6 percent of the total value of Japanese exports over the same period. The transformative effect of such remittances changed the perception of the communities they benefited. Oshima saw its moniker change from "potato eater’s island” to "Great Golden island” between the span of Kanyaku Imin and the start of World War II. ${ }^{100}$ Toshio Yasumatsu, in his own accounts, recalled his desire to return to Japan and build off of the wealth he had sent back in remittances. However, the effects of the World War altered his plans after he discovered the assets he had repatriated had lost their value. Of the situation, he stated:

The 150,000 yen I sent to Japan before the war had turned into nothing. After the war when I went there, I found out that the 150,000 yen hadn't even earned any interest after the war but remained there just as it was. Finally, the other day, in May, I gave away the papers from that bank. I said, Here, you can have them. They are useless. What could I do with 150,000 yen? In the old days in Japan, with 150,000 yen you could have bought considerable land before the war. ${ }^{101}$

The destabilizing effects of war on the Japanese economy had caused the value of Toshio's deposits to evaporate. The large sums he had deposited demonstrated the considerable effort Japanese laborers put forth into reinvesting in the communities they left behind. Persistent economic turmoil, first at the turn of the twentieth century and again after the Second World War, provided the impetus for Japanese laborers first to leave for, and then remain in, Hawaii. The large numbers of Japanese immigrants that flowed into Hawaii over the first decades of the twentieth century engendered charged rhetoric and racist commentary in print from the haole elite.

\footnotetext{
99 Dresner, 72.

100 Alan Takeo Moriyama, Imingaisha: Japanese Emigration Companies and Hawaii, 1894-1908. (Honolulu: University of Hawaii Press, 1985), 125.

101 Toshio Yasumatsu, 850.
} 
Official commentary on the inherent values of Japanese laborers reflected racialized notions of Asian inferiority. In his 1902 report to the United States Senate, the Commissioner of Labor extended paternalist overtones in his assessment of Japanese laborers, stating:

It is a general complain that the Japanese take advantage of their present predominance as laborers to shirk work and to soldier, and that they are insolent and undisciplined and inclined to pick trouble with their employer. Their faults, it is claimed, have a peculiar racial quality. In many ways the Japanese laborers are children, and possess an inordinate national and personal vanity. They are apt for this reason to resent any but the most tactful direction, and it becomes a very difficult matter to supervise them if they once feel that they are masters of the situation. ${ }^{102}$

The Labor Commissioner's remarks revealed a change in regard for Japanese laborers in Hawaii from a welcomed necessity during the Kanyaku Imin period to a nuisance needing control. Comparing the Japanese new arrivals to another stereotyped East Asian group, the Commissioner contrasted the Japanese proclivity to unruliness against a Chinese tendency towards obedience. He noted, "The Chinaman, on the other hand, is a sort of agricultural automation. Except for occasional attacks of hysteria, when a whole crew of then will fly off the handle for reasons entirely incomprehensible to their superiors, they are perfectly reliable for work within their capacity." ${ }^{\prime 103}$ He used the above description to argue for the continuation of limited Chinese labor to Hawaii. Annexation to the United State had subjected Hawaii to the restrictions of the 1882 Chinese Exclusion Act, which faced debate for its second extension in 1902. In response to white anxieties over Japanese immigration, the Labor Commissioner offered Chinese laborers as the model immigrant, though citing stereotyped and bigoted notions of their obedience, effeminate

${ }^{102}$ Report of the Commissioner of Labor on Hawaii, 1902, 53.

${ }^{103}$ Ibid. 
behavior, and limited capability and intelligence. Asian immigrant laborers faced harsh working conditions and systemic racism upon their arrival to Hawaii. Accounts from Japanese laborers themselves highlighted the difficulty of plantation life, underscoring their desire to enter more prosperous jobs in Honolulu and Waikiki.

Born on February 15, 1900 in a small farming village in Hiroshima Prefecture, Japan, Toshio Yasumatsu recalled the circumstances of his voyage over to Hawaii in 1917 and his years working on a sugarcane plantation in Waipahu, Oahu. The youngest of three brothers born to Kodama Masa and Yasumatsu Soichi, Toshio followed in his older brothers' footsteps, moving to Hawaii to work as a plantation laborer. His oldest brother had arrived on a company contract, sending first for his mother, and then the two younger brothers as they could afford it. Of the situation Toshio explained, "It was my older brother who already lived here who first sent for my mother. Then after my mother was here, she had the right to send for us children according to the government's rules. My [immediate] older brother and I came together on the same ship." ${ }^{104}$ His brother's prior arrival ahead of his allowed Toshio to avoid signing an unfair labor contract as his family afforded for his passage. Toshio and his family worked for a sugarcane plantation nonetheless, banding together as a non-contracted hui. Together with his two brothers and his oldest brother's wife, the four worked hapai ko (Hawaiian for loading sugarcane into train cars). One of the hardest harvest jobs on the sugarcane plantation, hapai ko required much physical strength to perform. Toshio recalled the painful process of learning the correct method to shoulder stacks of sugarcane stalks, stating:

There was a thick two-by-twelve inch piece of lumber on which they had nailed pieces of wood about a foot apart so that you wouldn't slip on it—-this is

${ }^{104}$ Toshio Yasumatsu, 831. 
what we walked on as we carried a load of sugar cane onto the car. The sugar cane was full of thorns and they would get stuck onto my hands like hair; but when I tried to remove them like this, I would be scolded. They would say, "What are you doing — just rub them. Then they'll get well.” See how soft my hands were when I had just come from Japan? And to have them pricked by the sugar cane - they are on the leaves — just touching them - I guess they are on the root of the plant. Just touching them, your hands would get covered with the [thorns] just like hair growing there, until they were white. So when I would be picking them off one at a time they would scold me and say just rub them together like this. Hapai ko is really hard work. ${ }^{105}$

Hapai ko formed the basis upon which plantation life revolved. Workers assigned this job received payment by tonnage loaded rather than hours work, allowing skilled huis the opportunity to become what Toshio considered "top moneymakers.” Performing hapai ko well accorded prestige to talented individuals. Plantation communities throughout Hawaii held hapai ko contests throughout the summer. Replicating plantation conditions in a competitive setting, teams of practiced plantation workers filled waiting train cars by hand. On June 3, 1919, The Garden Island reported the winner of the Kauai-wide hapai ko contest, noting, "Plantation people turned out in large numbers to witness the contest, several hundred people being present.” ${ }^{106}$ The local newspaper underscored the importance of the event to the broader community. Upon the conclusion of the year's final sugarcane harvest in the Fall, plantation communities held hapai ko dances to celebrate. ${ }^{107}$ Plantation activities provided communal space for Japanese new arrivals to integrate into Hawaiian working-class society. Waikiki laundress Miyo Asuka recalled her own immigration experiences, detailing the lifestyles led by Japanese immigrants outside of plantation work.

\footnotetext{
105 Toshio Yasumatsu, 833.

106 “McBryde Wins Hapai Ko Contest,” The Garden Isle. June 3, 1919, 1.

107 “Big Hapai-ko Dance Coming,” The Garden Isle. September 26, 1911, 1.
} 
Born on March 20, 1885, Miyo Asuka provided vivid detail of her passage to Hawaii where she came to reside in Waikiki, taking up work as a laundress. She grew up in a small coastal village called Itsukaichi in the Saeki Ward of Hiroshima Prefecture. She recalled that most of the people in her village worked as farmers, raising rice for harvest in the fall and wheat in the spring. Her husband's family had run an eating house in a neighboring village for over three hundred years. Rather than continuing proprietorship over the eating house, the couple chose to leave for Hawaii, following her husband's older brother much in the same way Toshio Yasumatsu had done himself. Miyo left Japan from Yokohama Harbor aboard the Chiyo Maru, arriving in Honolulu on June 8, 1914. The majority of U.S.-bound Japanese immigration flowed through Yokohama Harbor in the early twentieth century. As part of the vast effort to regulate the flow of peoples and goods into the United States, the Public Health Service established a maritime quarantine system that examined the health of inbound passengers and inspected ships and cargoes for potential pathogens. ${ }^{108}$ In the year of Miyo's arrival to Hawaii, U.S. Public Health Officials inspected and granted bills of health to 345 vessels leaving Yokohama for a U.S. port of call. Miyo herself recalled the quarantine procedures she underwent prior to disembarking, stating, "We had stool and duodenal examinations. There weren't too many who passed these the first time around." ${ }^{109}$ Miyo Asuka and her husband both passed on their first inspection. Statistics kept by the U.S. Public Health Service revealed in 1914 that out of 93,905 passengers inspected in

\footnotetext{
${ }^{108}$ Annual Report of the Surgeon General of the Public Health Serivce of the United States, 1914 (Washington: Government Printing Office), 119.

${ }^{109}$ Miyo Asuka, oral history interview with Michi Kodama-Nishimoto, February 20, 1985, Honolulu, O`ahu. In Waikiki, 1900-1985: Oral Histories Vol. 1 (Honolulu: Center for Oral History, Social Science Research Institute, University of Hawai‘i, Manoa, 1986), 896.
} 
Yokohama and issued immigration cards, 5,480 required a disinfectant bath and secondary inspection. ${ }^{110}$ Luggage of infected individuals received fumigation with sulfur dioxide gas. In cases of mass infection, both the cargo holds and passenger decks of entire ships received fumigation and visual inspection for animal pathogens, such as rats. The quarantine effort put forth by the United States in foreign ports demarcated nascent efforts to define clear national boundaries based on both geographic space and health of its constituents. ${ }^{111}$ The medical regulation of immigration projected the power of the national entity to judge which bodies possessed the inherent fitness to gain entry into the country, and thus become incorporated into the imagined national body. The process of quarantine and medical inspection continued once pre-examined vessels and passengers arrived on the nation's shores.

Stringent pre-immigration medical examinations slowed the entry for Japanese new arrivals to Hawaii. Aboard the Chiyo Maru, Miyo Asuka remembered waiting in port for two days before gaining entry to Honolulu as U.S. Immigration examined passengers from her ship and others. Of the event, she shared:

We arrived on June 8, 1914 at the immigration office. It happened that the ship prior to ours had some kind of bad illness on it. They were busy with the people with this illness, so the procedures for [the passengers] of our ship took some time. So we were detained at the immigration office for two days. On the tenth of June we came out. We arrived there on the tenth. ${ }^{112}$

Immigration and Public Health officials stationed in Yokohama reported a high incidence of typhus in the city and amongst would-be passengers beginning in March of that year.

${ }^{110}$ Annual Report of the Surgeon General, 1914, 171.

111 Alexandra Minna Stern, “Quarantine and Eugenics Gatekeeping on the US-Mexico Border” in Eugenic Nation: Faults and Frontiers of Better Breeding in Modern America (Berkeley: University of California Press, 2005), 59.

112 Miyo Asuka, 895. 
After recording 4,036 cases in the city, immigration officials amended procedures for all U.S.-bound passengers to include compulsory sanitation baths and twelve-day observation period. ${ }^{113}$ In May 1914, port officials quarantined a Pacific Mail steamship in Shanghai after its crew fell ill during its transit from Yokohama en route to Hong Kong. ${ }^{114}$ With knowledge of the typhus outbreak in Yokohama widespread, Honolulu immigration officials took further precautions in the processing of Japanese new arrivals. Public Health officials in Honolulu noted both the typhus outbreak in Yokohama and a specific instance involving the Chiyo Maru in their annual report to the Surgeon General. Of the latter, the report stated, "Japanese steamship Chiyo Maru arrived from Japanese and Chinese port on March 27, 1914, with the history of having landed a case of smallpox at Nagasaki. Nothing suspicious being found on quarantine inspection of the personnel, and as all necessary precautions had been taken, the vessel was accordingly granted pratique.”115 The fact that the Chiyo Maru had been the subject of quarantine inspection on its previous transit to Hawaii coupled with the increased incidence of typhus and other quarantine diseases in Yokohama gave evidence to Miyo Asuka's account of a long detainment and inspection upon her arrival to Honolulu. After her release from the Immigration Office, Miyo and her husband continued to her brother-inlaw’s property in Waikiki, known as the Asuka Camp, where Japanese families who did not own land of their own rented cottages as they found jobs in the emerging hotel industry.

\footnotetext{
${ }^{113}$ Annual Report of the Surgeon General, 1914, 172.

114 “The Korea Quarantined at Shanghai,” The New York Times. May 5, 1914, 7.

${ }^{115}$ Annual Report of the Surgeon General, 1914, 162.
} 
Beginning with competing notions of the Pacific Basin as either a seascape of opportunity and plenty or scarcity and exploit, Japanese and American maritime ambitions collided in the late nineteenth century. Scarcity of labor in Hawaii and the American West and difficult relations between farmers and the nascent Meiji government fueled the eastward migration of Japanese laborers. Fears of competition for skilled and unskilled labor positions and racialized rhetoric fueled scornful views of Japanese new arrivals both in Hawaii and the mainland United States. Upon arrival, Japanese workers integrated into Hawaii’s multiracial working class through participation in plantation activities, such as hapai ko contests and harvest festivals. In transit to Hawaii, Japanese immigrants experienced firsthand the medicalized process meant to exclude unclean, and thus unworthy, specimens from entry. Medicalized border crossing procedures developed enforceable boundaries for an imagined national body that excluded outsiders based on race and apparent health, declaring the unhealthy and outsiders as one and the same. Border control efforts matched nascent racial conceptions of nationality, making clear denotations that being “American” also meant being healthy, clean, and white.

\subsection{Predominantly Japanese Housing and Everyday Resistance}

Located in the Hamohamo neighborhood of Waikiki, the Asuka camp housed the Japanese immigrants who made their livings working as housekeepers and hotel workers. Miyo described the line of cottages on Paoakalani Avenue near Kalakaua Avenue, stating:

The yard was full of weeds. There in the yard there was this wooden, white, limecoated rowhouse. It was really shabby looking. Also there was a house with living quarters for two families--there were two of these. There was a rowhouse here and then came the yard and then in front of that was a common kitchen. Next to the 
kitchen was the bathhouse which was a separate unit. Next to that, that is, next to the street, there were two, two-family houses. So there were four families there-all Japanese. My brother's rowhouse had five or six families and that's where we came. They were all Japanese and all the men worked in hotels. The men were usually waiters. ${ }^{116}$

The rowhouse and two cottages provided homes for ten families in total on the Asuka lot. The units lacked electricity and in-home plumbing. Built on low-lying, relatively remote land, the Asuka Camp did not benefit from connection to municipal sewerage or water. As Miyo reported was common for Japanese in Waikiki, her husband found employment at the Halekulani Hotel as a yard worker. In 1914 when Miyo’s husband first began working at the Halekulani, he made eighteen dollars a month. Faced with affording three dollar rent at the Asuka camp, food, and other incidental expenses, Miyo arranged to do laundry for wealthy vacationers at the Halekulani to supplement the couple’s income. Japanese women at the Asuka camp often engaged in reproductive, or domestic, labor outside of the home. While most found employment in the households of local wealthy families, Miyo displayed her ingenuity in offering services to the visiting tourists. Using her husband's interactions at the hotel, she worked from home, cleaning guests' garments by hand and pressing them with a charcoal iron. Her husband carried the laundry back and forth between home and work on his bicycle. Of the work, Miyo recounted, "People were envious of me because, in contrast to the laundry of people in the vicinity which was dirty, the laundry of the guests in the hotels was [relatively] clean and we could charge more for it. People would tell me how lucky I was. Every week I would get about seventeen dollars." 117 Visitors who had few other alternatives for laundry service at the

\footnotetext{
116 Miyo Asuka, 897

${ }^{117}$ Miyo Asuka, 900.
} 
time paid better rates than did the local families for which other women worked. Miyo made in a week almost as much as her husband received in an entire month. The income both wage earners made together allowed the couple to buy the Asuka Camp from Miyo’s brother-in-law. In 1918, after the couple had returned from a stay in Japan, Miyo's brother-in-law offered the location to them, as he wished to open a store downtown. ${ }^{118}$ Toshio Yasumasu corroborated Miyo’s recollection of the events in his own interview, stating:

That was no problem. Asuka-san's older brother used to have that place. In order to buy a small store on Vineyard, he said he would sell it; so the Asukas bought it. I guess they were lucky. Recently, in order to broaden the street, they said they were going to knock off one room. The other side paid for this and they received some money for the land. That was $\$ 200,000$. The late Mr. Asuka had said, "This must be a writing error. One digit is a mistake."119

Though they moved off of the property in 1938 after purchasing a nearby property on Kuhio Avenue, the Asukas retained ownership of the property, eventually seeing profits from the region's development. The Asuka camp represented only one of an assortment of housing camps in the Hamohamo neighborhood that catered to Japanese hotel workers. Toshio Yasumatsu revealed some of his memory of living on such a camp owned by the Moana Hotel during the sugarcane plantation strike of 1920 before he made a permanent move to Waikiki.

In order to provide housing for employees who could no longer afford to live in Waikiki, the beachfront hotels established permanent camps inland. The sugar strike of 1920 left Toshio Yasumatsu needing work for four months during that year. Spurred in January by collective bargaining from Japanese and Filipino labor associations for both

\footnotetext{
${ }^{118}$ Miyo Asuka, 909.

119 Toshio Yasumatsu, 848.
} 
an increase in the basic wage and change in bonus structure disbursed to qualifying workers, out of work employees, such as Toshio sought housing and work off of the plantations to support their livelihoods. ${ }^{120}$ In this time, Toshio learned to work in the pantries at the Moana Hotel. Of the experience preparing desserts for visitors, he stated, “The work was easy. If they told us that today the ice cream would be such and such, they would bring it over and, for instance, if they wanted strawberry and vanilla that day, you just had to bring it up. If there were any leftovers, they didn't use it the next day...They told us we could take it home if we wanted it so we would put it in boxes and take it home.”121 The employees of Moana Hotel received the option to rent living space in company-owned cottages in the Hamohamo neighborhood. Located in an unpaved lot between 'Ohua and Paoakalani Avenues, the camp, according to Toshio, consisted of "two rows of cottages. There was a front and back [row]. Next door was Murakami-san and in front was Yoshimura-san and Takashige-san.”122 Living with his wife and children, Toshio qualified for single-family house and could recall his neighbors well. The camp had two main sets of cottages, one side set up for individual families, and the other as a dormitory for the single men who worked as bellhops and room boys. Toshio's wife, Taka Yasumatsu, recalled that their cottage had two rooms including its own living room and kitchen. ${ }^{123}$ The single men’s dormitory, by contrast, had a communal bathroom and kitchen, akin to the living situation at the Asuka Camp. While the Yasumatsus provided a good image of the physical landscape of the camp, other

\footnotetext{
120 “Plantations on Oahu Tied Up by Strike,” Maui News. January 23, 1920, 1.

121 Toshio Yasumatsu, 834.

122 Toshio Yasumatsu, 836.

123 Ibid.
} 
interviewees offered memories of everyday life and the activities that occurred between hotel camp residents.

Everyday activities and interactions between hotel camp residents helped form social bonds between working-class residents of different ethnicities. Chinese-Hawaiian longtime Waikiki resident Bernice Chow Tomigawa recalled her experiences growing up in the Moana Hotel housing from 1918 until about 1935 when she married her husband, an issei Japanese man who worked for the Royal Hawaiian Hotel. Born in Ala Moana to local Chinese parents in 1915, Bernice's experiences did not entirely match those of the issei Japanese immigrants who formed the majority of the hotel worker population. However, Bernice recalled that communal interactions and the practice of talking story brought her and her family closer to their neighbors. Noting the Maeda family as good friends to hers, Bernice lamented, "When the Maeda family became my neighbors, that was in summer of 1930. We were intermediate age, so we didn't play those games that children in the elementary played. We just used to play, and talk stories, and go the beach and go swimming." 124 Talking story developed on the plantations throughout Hawaii as a means of sharing common, everyday experiences between peoples coming from a multitude of ethnic and linguistic backgrounds. Told in Hawaiian Pidgin, the common language developed to share information between diverse groups of immigrants, the stories told kept alive the memories and cultural practices of Hawaii's new arrivals that may have otherwise died with their original storytellers. ${ }^{125}$ Talking story encouraged

\footnotetext{
${ }^{124}$ Bernice Chow Tominaga, oral history interview with Michi Kodama-Nishimoto, February 5, 1986, Manoa, O‘ahu. In Waikiki, 1900-1985: Oral Histories Vol. 1 (Honolulu: Center for Oral History, Social Science Research Institute, University of Hawai‘i, Manoa, 1986), 1990.

${ }^{125}$ Michi Kodama-Nishimoto, Warren Nishimoto, and Cynthia A. Oshiro, Talking Hawai 'i’s Story: Oral Histories of an Island People. (Honolulu: University of Hawaii Press, 2009), x-xi.
} 
casual conversation between participants, providing both relief from the hardships from plantation and other forms of immigrant labor, as well as space for unguarded talk. In short, talking story allowed storytellers the opportunity to resist cultural colonization and assimilation within the dominant, Westernized culture of the planter elites. Resistance in the form of talking story often eluded the awareness of the white elite, giving it added value. Countering the myth of peasant passivity to exploitation by capitalist and hegemonic powers, Anthropologist James C. Scott identified "offstage” comments and conversations, "proverbs, folksongs, and history, legends, jokes, language, ritual, and religion,” as key indicators of everyday resistance that eluded detection from social elites and thereby the historical record left behind by those in power. ${ }^{126}$ The practice of talking story served as a form of everyday resistance that working-class individuals from many ethnic origins adopted as a form of comfort and shared identity. Sharing her experience enrolling in welfare services upon her husband's layoff upon the closing of the Hamakua Sugar Company in 1994, Dardenella Mae Gamayo revealed the comfort of talking story with a social worker through the process. Of her experience, she stated:

A couple of 'em came out. I can't even remember what kind agencies had out there. A couple of 'em went out. They had one that came out and they did surveys. They went house to house. They had former sugar workers, they trained 'em on social service work. And they would talk story. "Eh, how you doing brah?" You know, talk story, bring the paper and pencil, just kind of take notes. If not they would just kind of eyeball it, just kind of look around, see what, you know—But not many of 'em. ${ }^{127}$

\footnotetext{
${ }^{126}$ James C. Scott, Weapons of the Weak, 41.

${ }^{127}$ Dardenella Mae Gamayo, oral history interview with Warren Nishimoto, January 15, 1997, Honoka'a, Hawai'i. In The Closing of Sugar Plantations: Interviews with Families of Hamakua and Kau, Hawaii, (Honolulu: Center for Oral History, Social Science Research Institute, University of Hawai 'i, Manoa, 1997), 511.
} 
Dardenella recalled that the social workers who solicited government aid to displaced families after the closure of the sugar mill had also worked as plantation operators, which helped gain her trust. Spending time with her through the process and talking story helped her develop trust in the social worker. In the same exchange, Dardenella recalled the distrust she harbored for government officials in general. When she appeared at her local county clerk's office to file for welfare, she recalled the differential treatment she received, stating:

I don't know if these welfare workers realize what they doing, but they kind of stereotype people on welfare, maybe, I guess. You know I walked in there, filled out the application, and the worker says, "Oh, Mrs. Gamayo. Who-" literally, this is how he talked to me. He said, (She speaks in a slow, condescending manner) "Mrs. Gamayo, who helped you fill out this form?"

And I looked at him, "Nobody. Me."

"You filled this out, (She speaks very slowly) all by yourself?"

"Yeah."

"Oh, okay."

So I'm looking him like, how dare this guy. You know, wow, why you talking to me like this? But then I no figure nothing, right? Maybe he figure, I get one handicap or, (chuckles) I don't know. Or maybe I no more one education. ${ }^{128}$

The exchange Dardenella had with the government official exposed the dynamics that tinged relations between working-class people and those in power in Hawaii. Speaking in simple, slow English, the county official made a value judgement of Dardenella and her level of education. In contrast, the exchange she had with the social worker, carried in Hawaiian Pidgin, comforted Dardenella, allowing the social worker to perform his duties in making sure she received aid. Dardenella's experience talking story mirrored Bernice's experiences in Waikiki. Talking story helped her gain the trust of her issei Japanese neighbors.

${ }^{128}$ Ibid. 
For Bernice, talking story with her new arrival neighbors earned her their confidence, and allowed her to bond with the young, single men who worked at the Royal Hawaiian and Moana Hotels. Noting that she spent her summers swimming and surfing with the young hotel workers, she remarked:

When I was a teenager I loved to go swimming right in front of the Moana Hotel. That's where I met my husband. My husband worked for the Royal Hawaiian [Hotel]. He lived in the camp. He worked for the Royal Hawaiian as a bell boy when he was young, teenager days. They used to make pretty good tips, you know. But during the depression, well, not so. And then, he used to take me surfing. I used to go surfing with him. But when I got to be about almost sixteen-yeah, when I was about fifteen and a half--I used to work during my summer months. We had no time to go surfing or swimming. ${ }^{129}$

The camaraderie engendered through casual social interaction such as swimming and talking story brought Bernice closer together with her neighbors and her eventual husband. Talking story provided adult residents with the opportunity to bond and develop mutual understanding, as well. Bernice recalled that the grocery peddler's rounds through the camp provided opportunity for conversation, stating, "The Japanese peddler would come, maybe twice a week. There were two peddlers, you see. The housewives would get together and talk a few words to each other." ${ }^{130}$ In an environment where women spent their daytime hours either cleaning laundry for clients in their homes, as Miyo Asuka did, or otherwise finding work within the households of the rich outside of Waikiki, the arrival of the grocery peddlers gave them reason to take a break and talk story with each other. However, as the Japanese population in Waikiki grew, residents sought new ways to keep in touch with each other's lives. Sparked by the desire to

\footnotetext{
${ }^{129}$ Bernice Chow Tominaga, 1993.

${ }^{130}$ Ibid.
} 
promote community amongst the Japanese population of Waikiki, the Aloha Kai society developed as a way to promote multicultural unity.

From the starting point of Miyo Asuka's recollections of life on his family's Hamohamo camp for Japanese hotel workers and their families, a picture of cultural admixture and resistance to hegemonic influence developed. The housing camps of Hamohamo provided space for issei Japanese who worked in the hotel and related service industries, such as laundry cleaning, to bond and develop connections with other residents of Waikiki. Out of the necessity of generating enough income for survival, the men and women of the housing neighborhoods formed small household economies around performing domestic labor, such as taking in laundry for the wealthier surrounding families, or peddling produce and other wares outside of homes. The routine of talking story, whether between flirting teenagers at the beach, or between housewives observing the street peddlers' wares, formed a practice of everyday resistance for working-class residents against cultural colonization. Through the discussion of daily happenings and shared positive experiences, housing camp residents such as Bernice Chow Tominaga developed feelings of acceptance and unity in a multi-lingual, mixedrace environment. As part of that unity, community promotion and outreach found new importance with Hamohamo residents as they formed the Waikiki Aloha Kai.

\subsection{Waikiki Aloha Kai and Japanese Amalgamation}

The Waikiki Aloha Kai formed as a community organization for issei Japanese and their children to gather and celebrate their cultural heritage. Toshio and Taka Yasumatsu recalled that the club started as a group of families that hosted get-togethers 
for weekend picnics and New Year’s celebrations. In 1931, by Taka’s memory, local business owner Eisuke Kuniyuki founded the Aloha Kai to provide an organized structure to inform Waikiki area Japanese families of upcoming events in the community. ${ }^{131}$ The name 'Aloha Kai' came from the combination of the Hawaiian word for 'greetings and love’ with the Japanese one from 'club or society.' The name's synthetic nature represented issei Japanese desires to integrate into Hawaiian society while also retaining their ethnic identities. At the time of his interview in February, 1985, Toshio detailed that he still received notices through the Aloha Kai network, stating:

It's already set that every year they will have the New Year's Party and the picnic. They never fail to at least have these every year. If there's going to be a funeral, I would call five people on the telephone, and those five people in turn would call about four more people each. So people are informed very quickly by phone. If I call five people, then those five would call about four others; those five people calling four each would add up to twenty people, and about six or seven people are doing this--so it goes very quickly to let people know that somebody died. ${ }^{132}$

Fifty years after its inception, the Aloha Kai served to keep issei Japanese aware of each other's happenings, even as funerals began to outnumber picnics in the community. Beyond tying the Japanese community together, Aloha Kai hosted events that integrated its members into the community-at-large. Former Waikiki resident Masayuki Yoshimura remembered that Aloha Kai served as a cultural outreach to interested gaijin, "foreignborn” or non-Japanese, community members. Growing up in Hamohamo, most of Masayuki's friends came from either Japanese or Part-Hawaiian descent. The level of ethnic integration between the neighborhood children fomented mutual interest in each

\footnotetext{
131 Toshio Yasumatsu, 846.

132 Toshio Yasumatsu, 847.
} 
other's cultural observances. Masayuki recalled jovial interactions with the local gaijin in the community, stating:

Nighttime, sometimes, we go out to the stone wall, talk story. All the Japanese, all the Hawaiian boys, we go down there, talk story, get together. Good. Waikiki was a very good place for the Cosmopolitan people to get around. Very harmonized. People really get together. We even had bon odori. Some of the Hawaiian boys used to go Japanese[-language] school with us. The family make 'em go Japanese school, some of them. ${ }^{133}$

Aside from the New Year's parties and weekly picnics, which catered primarily to member families, the summer Obon Festival, or bon odori, represented the largest community event held by Aloha Kai each year. Open to broader community participation, bon odori celebrated paying homage to one's ancestors as well as offering prayer for an abundant harvest. Masayuki recalled that the Aloha Kai held its bon odori on 'Ohua Avenue outside of the Asuka and Moana Hotel camps. Members from the club played taiko drums and sang as Japanese and gaijin alike encircled the performers, dancing throughout the night. Beyond the social function of providing community outreach, the Aloha Kai banded Japanese residents together against a hostile, anti-Asian immigration white American public.

Against a backdrop of increasing nativist, populist, and xenophobic rhetoric following the conclusion of the First World War, Japanese immigrants and their American children experienced increased prejudice in Hawaii and the U.S. Mainland. The rise of nationalism along racially-defined lines saw Japanese and other non-white populations marginalized further as threats to the continued progress of the nation. In a 1923 letter marketing Hawaii to Los Angeles Times readers, Hawaii politician and

133 Masayuki Yoshimura, oral history interview with Michi Kodama-Nishimoto, April 23, 1986, Kapahulu, O‘ahu. In Waikiki, 1900-1985: Oral Histories Vol. 1 (Honolulu: Center for Oral History, Social Science Research Institute, University of Hawai‘i, Manoa, 1986), 1460. 
publisher, Lorrin A. Thurston identified issei and nisei Japanese residents as the Islands' potential "great problem." 134 He used his own racist reasoning to grapple with the view of "statistical pessimists" on the mainland that saw the the Territory's nonwhite majority as a threat to its Americanization. Before attempting to dispel fears of 'the Japanese specter” over Hawaii, Thurston wished to reassure his mainland audience that he and other "Americans of Hawaii are of the same brand which came to Hawaii a century ago, and, in an altruistic spirit, civilized and Christianized a savage race.”135 Thurston’s remarks revealed his belief in Euro-American exceptionalism and his paternal outlook towards nonwhite peoples. Addressing mainland concerns over the territory's large Japanese population, Thurston continued:

But the alien (issei) Japanese do not constitute Hawaii’s problem. They are not eligible to citizenship; they cannot vote. In a generation or so the will have passed on...The American-born of Japanese parentage - they indeed constitute Hawaii's greatest problem, differing entirely from that incident to their parents. The latter are not, and never can become, voters; as a rule, they neither speak, read, nor understand more than a smattering of English, and have but the vaguest knowledge of American ideals and institutions. Even to those who know them best, what the American-born Japanese will do as citizen voters, still is a matter of surmise. ${ }^{136}$

Thurston's remarks echoed the renewed fears of "Yellow Peril" held by white American policymakers, especially in the west, during the interwar period. Thurston's remarks preceded the passage of the Immigration Act of 1924 by the U.S. Congress. In an effort to "preserve the ideal of American homogeneity," the act placed heavy restrictions on the number and origins of incoming immigrants to the United States, placing strict quotas on

\footnotetext{
${ }^{134}$ Lorrin A. Thurston, "Hawaii: What it is. What it has. What it needs. Its great problem.” Los Angeles Times. January 21, 1923, 7.

135 Ibid.

${ }^{136}$ Ibid.
} 
Eastern European and Jewish arrivals, while effectively excluding all new Japanese and Chinese immigration. ${ }^{137}$ Widespread skepticism over their ultimate loyalties dogged nisei Japanese-Americans despite their American upbringings. As the membership of Aloha Kai grew older and began incorporating younger generations of Hawaii-born Japanese Americans, the club activities reflected the hybrid nature of the Japanese community.

Beyond hosting bon odori every summer, Japanese residents organized other events, including surf outings and baseball leagues, encouraging outreach to the nonJapanese population. Masayuki Yoshimura shared his memories organizing a surf club called Nami-no-Kai. A tongue-in-cheek reference to the more prolific Hui Nalu, Masayukui explained the origins of his club and its name, "Yeah, I started a surfing club. You know, Waikiki, I started a surfing club, and I named it Nami-no-Kai because almost all Japanese on our club, see. But since everybody like to join the club, they get free Tshirt because I make for them. So we had the T-shirt and we call ourselves, "Nami-noKai." Nami means "wave," see. Kai means “club.” Wave club, eh? Nami-no-Kai.”138 Unlike the surf activitist club from which it took its name, Nami-no-Kai served simply as a social organization for Masayuki and his high school group of friends. Waikiki Beachboy Mervin Richards recalled surfing with Nami-no-Kai, but remembered more clearly playing baseball with Masayuki and the other club members, stating, ""Mahjong" Yoshimura formed a baseball league called "Nami-no-kai." There was about five teams involved in there with boys from Waikiki and other districts that always used to come

137 “Immigration Act of 1924," United States Statues at Large. Sixty-Eighth Congress, Session I, Chapter 190, 153-169.

138 Masayuki Yoshimura, 1462; “Hui Nalu” takes its name from the Hawaiian for “Wave Club.” 
surf at Waikiki. We made about five teams. And we played at the McKinley High School field which ended up we winning the championship." ${ }^{139}$ Masayuki ran the league as a way to bring together young men from districts throughout Honolulu who interacted with each other in other venues as rival neighborhood gang members. On setting the teams, Masayuki recalled, “I divide 'em up equal so that everybody can play. I'm the manager of the team [league], so they got to listen to me what I tell them guys. No trouble at all.” ${ }^{140}$ Masayuki enjoyed brining together diverse groups of people together in the name of sport and competition. Taking his role as league commissioner seriously, he organized a tournament in which the participating teams competed for a prize. He solicited local businesses and street pedlers for donations. He remembered the street peddler who frequented the Moana Hotel camp and a particularly giving source, stating:

I used to even stop the peddlers. You know, the peddlers? Old days, they have the peddlers come sell food to camp. So I used to tell 'em, "O-san, you can donate one gallon shoyu (soy sauce) for door prize?"

"Yeah, okay"

Anything to get something for the door prize, you know. ${ }^{141}$

Masayuki's activities with the broader community demonstrated the level of integration exhibited Japanese residents of Waikiki. Far from Lorrin A. Thurston's feared threat to American culture, locals of Japanese descent found themselves at home in the hybridized society taking root in Hawaii. Masayuki’s racially-integrated Nami-No-Kai and baseball leagues proved an effective counterexample to the xenophobic, populist ideologies perpetrated by Thurston and other social elites in Hawaii and on the mainland who

${ }^{139}$ Mervin Richards, oral history interview with Michi Kodama-Nishimoto, March 7, 1985, St. Louis Heights, O'ahu. In Waikiki, 1900-1985: Oral Histories Vol. 1 (Honolulu: Center for Oral History, Social Science Research Institute, University of Hawai ‘i, Manoa, 1986), 698.

${ }^{140}$ Masayuki Yoshimura, 1462.

${ }^{141}$ Ibid. 
wished to labeled Japanese people in Hawaii and Japanese-Americans as interlopers who could never assimilate into local culture.

Japanese cultural and community organizations such as the Waikiki Aloha Kai and Nami-No-Kai demonstrated successful attempts in cultivating outreach and mutual understanding amongst the working class residents of Waikiki. Much in the same way that talking story provided common ground for understanding between multiethnic neighbors, culture events such as bon odori celebrations and Japanese language schools played the dual purpose of immersing the Japanese diaspora in their own culture, as well as offering education to interested non-Japanese people. Celebrating cultural diversity amongst the Japanese and non-Japanese residents of Hamhamo helped unite like-minded, working-class groups against the hegemonic influence of the planter elite. Publisher and journalist Lorrin A. Thurston, himself from a missionary and plantation owner family, wished to identify first- and second-generation Japanese immigrants as Hawaii’s "great problem,” due to their immutable foreign allegiances. Examples such as Masayuki Yoshimura’s Nami-No-Kai surf club seemed to defy not only Thurston’s racialized polemics, but also scholarly discourse surrounding racial division on the waves. Isaiah Helekunihi Walker drew the surf zone, or ka po 'ina nalu, of Waikiki along strict racial lines where "Hawaiian men regularly flipped colonial hierarchies and categories upside down." ${ }^{142}$ Perhaps outside of the purview of Walker's analysis, Japanese men such as Masayuki appeared to use the surf zone as a racially fluid space in harmony with his nonJapanese friends. Of course, Japanese surfers may have had such limited access to surf

142 Isaiah Helekunihi Walker, "Hui Nalu, Beachboys, and the Surfing Boarder-lands of Hawaii." The Contemporary Pacific 20, No. 1 (2008). 89. 
due to the strength of the Native Hawaiian and haole surf clubs that they required protection from their non-Japanese neighborhood friends. In either case, the rise of Japanese cultural organizations pointed toward their overall increasing acceptance within multicultural communities. Utilizing similar outreach overtures, Japanese-owned businesses and business associations began to flourish, as well.

\subsection{Japanese Businesses in Hamohamo}

The predominance of the Japanese population in Hamohamo precipitated a corresponding rise in Japanese-owned businesses in the district. Part-Hawaiian resident Esther Bader recalled developing strong relations with the shop owners on Kalakaua between 'Ohua and Paoakalani Avenues, stating:

Because we had to pass that laundry to get to Tahara's first restaurant. See, he was (close) on ('Ohua Avenue) side. And then, for some reason, he ended up on this side, (Paoakalani Avenue). The same thing goes for Aoki Store at the corner of 'Ohua and Kalakaua [Avenues]. It used to be on Paoakalani. Ibaraki was on the other side. So, for some reason, these two switched places...We all knew each other so much because we went to school with the kids. The children from Ibaraki Store and Aoki Store, we all went to Waikiki [Elementary] School. So we got to know one another real well. ${ }^{143}$

Esther's interaction with the children of the issei Japanese shop owners gave her a more intimate understanding of her neighbors, allowing her to recalled the smaller details, such as when the Aoki and Ibaraki Stores traded locations. Japanese-owned businesses developed first to support the communities living in the Asuka Camp immediately behind the commercial district, and the Moana Hotel workers’ camp further inland. However, as they built up a clientele from the surrounding Hawaiian and haole communities, the

${ }^{143}$ Esther Bader, 421-422. 
Japanese-owned businesses began carry hybridized offerings that borrowed from Japanese and local culture to satiate a broader range of tastes. Soichi Tahara's Unique Lunch Room developed as one of the most prominent of a new category of restaurants and businesses that offered products made from Japanese and Hawaiian cultural influences to mass appeal. As confirmed by his daughter, Helen Kusunoki, Tahara’s restaurant became "one of Honolulu’s early plate lunch places," a type of carryout cuisine developed from multiethnic origins that arose first on the plantations of Hawaii. ${ }^{144}$ Japanese businesses in Hamohamo, such as Tahara's restaurant, experienced success in part due to advocacy groups such as the Honolulu Japanese Chamber of Commerce providing support and outreach to the greater community. Combatting the national discourse of increased prejudice and skepticism towards Japanese business efforts, the Japanese Chamber of commerce engaged in community service efforts and brought prominent statesmen to Hawaii to promote greater cooperation from both sides of the Pacific. Looking at the contributions of business organizations and shop proprietors in conjunction, a clearer image of cultural amalgamation and acceptance developed.

Born in Honolulu on July 20, 1918, Helen Kusunoki witnessed the rise of Japanese businesses in Hamohamo firsthand, working for her father's successful restaurant, the Unique Lunch Room. In common with Toshio Yasumatsu and other issei arrivals, Helen's father immigrated to Hawaii to pursue work in the sugarcane industry. However, unlike Toshio, he arrived on a hui contract for a plantation in Kohala, Hawai ‘ $\mathrm{i}$

${ }^{144}$ Helen Kusunoki, oral history interview with Michi Kodama-Nishimoto, May 16, 1986, St. Louis, O‘ahu. In Waikiki, 1900-1985: Oral Histories Vol. 1 (Honolulu: Center for Oral History, Social Science Research Institute, University of Hawai'i, Manoa, 1986), 1385. 
Island. ${ }^{145}$ Helen recalled that her father, Soichi Tahara, arrived in Hawaii in 1909, but could not pinpoint his arrival to Waikiki, noting that by the time of her birth, he worked as a waiter at the Moana Hotel. The family settled into a two-story cottage at the intersection of Paoakalani Avenue and Cartwright Road, just behind the Lemon Estate. Helen's father worked part-time as a cook for the Lemon family during his employment at the Moana, which helped the family secure the cottage nearby. Lemon "Rusty" Holt recalled Taraha’s time with the Lemon family, stating:

Tahara cooked for my family for quite a few years until he decided to get married, and he married a lady from Japan, the nicest person you ever want to know...He worked for our family for quite a while until he decided to start his own business. Then he started the Unique Ice Cream Parlour and then switched to Hawaiian foods. Custard pie, the best custard pie made in the world, at Tahara's. ${ }^{146}$

Known throughout Waikiki by his last name, Tahara set a good impression on his neighbors. Part-Hawaiian Hamohamo residents Esther Bader and Mervin Richards both recalled Tahara’s Unique Lunch Room for its delicious, affordable food and impecable pies. ${ }^{147}$ Esther recalled a particular exchange she had with him over the popularity of establishment, stating:

So, one day, I said to him, "Tahara, why don't you expand--" Because his daughter started to rent the shop right next to him as sort of a drugstore. She had that. I can't remember her name. I think it was Lillian. I asked him, "Why don't you enlarge and go into Lillian's place? She doesn't need all of that."

He said, "No. I stay right here. If they want to come and eat my food, they wait." And by golly, we all waited. ${ }^{148}$

${ }^{145}$ Helen Kusunoki, 1380.

${ }^{146}$ Rusty Holt, oral history interview with Michi Kodama-Nishimoto, February 26, 1985, Wilhelmina Rise, O‘ahu. In Waikiki, 1900-1985: Oral Histories Vol. 1 (Honolulu: Center for Oral History, Social Science Research Institute, University of Hawai‘i, Manoa, 1986), 785.

${ }^{147}$ Esther Bader, oral history interview with Michi Kodama-Nishimoto, March 6, 1985, Waikiki, O‘ahu. In Waikiki, 1900-1985: Oral Histories Vol. 1 (Honolulu: Center for Oral History, Social Science Research Institute, University of Hawai‘i, Manoa, 1986), 424; Mervin Richards, 678.

148 Esther Bader, 424. 
Through catering to local tastes for Hawaiian staple foods and building confidence with his customers, Tahara's business proved successful. Established in the 1920s alongside neighboring Japanese-owned businesses, Tahara’s story reflected the rising status of Japanese immigrants within local commerce and society.

Tahara's restaurant gained popularity at a time when issei Japanese immigrants began to open establishments in Hamohamo to serve both their own community and the broader Waikiki population. Throughout the 1920s until its rebuilding and renovation in 1935, Japanese shop owners predominated the commercial district on Kalakaua Avenue along 'Ohua and Paoakalani Avenues. Helen Kusunoki and Harold Aoki, among other Hamohamo residents painted a vivid image of the commercial district's layout. Traveling down Kalakaua Avenue towards Diamond Head, one passed Tahara’s restaurant first before arriving at Old Man Tailor's Laundry, the Kuniyuki family’s taxi stand, Mrs. Kobara’s barbershop, Toshio Yasumatsu’s Kapi`olani Cleaners, and finally the Aoki Store. ${ }^{149}$ Japanese businesses flourished to become neighborhood staples. Harold Aoki, a nisei Japanese born in Waikiki in 1910, remembered that his father's store attracted customers from the entire area, stating:

All the people behind the Aoki Store [shopped there]. Well, sometime later, Asuka--the camp, they used to have. Sasaki, and then these Ewalikos, and then this Freitas. Freitas came in way back. But when we first went there, not much. Only "Rusty" Holt's family was right next door. Then, the following corner was Cunha. C-U-N-H-A. Cunha. They used to have big yard and one house. Big yard. ${ }^{150}$

${ }^{149}$ Collected from descriptions provided by Helen Kusunoki, 1381-1382; Harold Aoki, 737-738; Mervin Richards, 678. Locations date to the period circa 1927-1935, after the the Yasumatsus' purchase of Kapi 'olani Cleaners and before the rebuilding of the commercial district.

${ }^{150}$ Harold Aoki, oral history interview with Michi Kodama-Nishimoto, March 19, 1985, Waikiki, O'ahu. In Waikiki, 1900-1985: Oral Histories Vol. 1 (Honolulu: Center for Oral History, Social Science Research Institute, University of Hawai ‘i, Manoa, 1986), 732. 
As the only store in the neighborhood that offered fresh groceries, the Aokis attracted business from Japanese hotel workers living in the nearby Asuka camp, as well as the Hawaiian and haole families that lived in large estates. Harold noted that his father's clientele built up over time as the non-Japanese population came to trust the Japanese business owners. He stated that even Prince Kuhio and Princess Elizabeth Kahanu Kaauwai Kalaniana'ole came to purchase household goods for their beach estate on the opposite side of the block. ${ }^{151}$ Helen Kusunoki recalled that as her father's business flourished, customers began to request Japanese inclusions with their Hawaiian favorites, preferring their pipi kaula (salted, dried beef rope) fried in soy sauce and garlic and served over rice. ${ }^{152}$ Helen noted that the demand for popular Hawaiian food items on a plate over rice reflected a cultural shift in the local community. Of the phenomenon, she stated:

After the ice-cream parlor, he [Tahara] had one, two, three, about four tables and about four chairs to a table. So people used to wait outside in front of the store. People waiting to get in. I mean, because they can come as is. And of course, some of them would come and say, oh, they want sandwiches or if we could fix lunch so they can take it with them and eat at the beach. So my father would put it in the paper plate--beef stew and rice, hamburger steak. And even the poi and pipi kaula, later on, he made it so they can take it out. Because they can't wait outside for the tables. ${ }^{153}$

Borrowing the concept of boxed lunch from the familiar Japanese obento, Tahara and his restaurant served as one of the pioneers of the Hawaiian plate lunch. The believed origins of the plate lunch arose on the plantation where cultural admixture paired Hawaiian and haole meat dishes with the Asian staple rice for a filling and portable

${ }^{151}$ Ibid.

${ }^{152}$ Helen Kusunoki, 1384.

${ }^{153}$ Helen Kusunoki, 1385. 
meal. ${ }^{154}$ As leisure activities, such as beachgoing, gained popularity with ongoing modernization processes, the plate lunch transitioned from working-class to popular culture. The broader adoption of Japanese food preferences and plate lunch indicated an increased acceptance of Japanese residents and their businesses in Waikiki. The congeniality expressed between Japanese and non-Japanese peoples in Waikiki contrasted the adverse treatment received from national policymakers and the local elite. Much of the positive relations Japanese business owners developed with their local communities stemmed from outreach efforts set forth by professional organizations such as the Japanese Chamber of Commerce and the Japanese Merchants’ Association.

Founded on March 12, 1900, the Honolulu Japanese Chamber of Commerce promoted the interests of Japanese business owners through liaison efforts including rights advocacy and community outreach. Already viewed with skepticism and distrust by the upper-class white population as demonstrated through Lorrin A. Thurston's remarks, Japanese professional organizations developed to combat unfair treatment under the law. As part of the effort to improve treatment for Japanese populations in Hawaii and the mainland United States, the Honolulu Japanese Chamber of Commerce hosted banquets for visiting Japanese dignitaries passing through on their way from Japan to California, Washington D.C., and New York. On November 2, 1915, during the height of the First World War, the Japanese Chamber of Commerce along with the Japanese Merchants’ Association hosted Baron Shibusawa Eiichi, a prominent industrialist and philanthropist heading a diplomatic mission to the Eastern United States. ${ }^{155}$

154 “Carbo-Loading, Hawaiian Style,” New York Times. November 12, 2008.

155 "Noted Japanese Says America Must Take Lead in Pace Work," Honolulu Star-Bulletin. November 2, 1915, 8. 
Acknowledging the tension between Japanese populations throughout the United States and the communities in which they lived, Baron Shibusawa urged that improved relations between the two would serve as a strong first step toward broader peace in the global conflict. Press coverage of the event reported, "The spirit of the evening was one of cordiality between Americans and Japanese as promoting cordial relations between the two nations." 156 As an official emissary of the Japanese government, Baron Shibusawa looked for improved treatment of Japanese immigrants from his wartime allies. For its part, the Honolulu Japanese Chamber of Commerce lent its support to broader national initiatives for improved treatment of Japanese populations living in the United States. Baron Shibusawa's meeting with the Chamber of Commerce occurred amidst failed efforts by the latter to lobby against the Anti-Alien Land Law passed in California two years earlier. In that instance, Japanese lawyer and economist Soyeda Juichi spoke with the Chamber of Commerce and the Japanese Merchants’ Association in Honolulu en route to Sacramento in order to protest the bill’s passage. In his May 19, 1913 speech, Soyeda intimated:

My mission to California, and possibly to Washington, is simply to express to my people in America, on behalf of the Japanese Chambers of Commerce, our sympathies with them in their present predicament. I also hope to get their attitude upon the question. Also I wish to get a clear idea of conditions in California and in America and of the attitude taken by the majority of the American people [on the issue]. ${ }^{157}$

The active participation in regional and national politics concerning Japanese populations throughout the United States exhibited by professional organizations in Honolulu demonstrated the interconnections between ethnic Japanese throughout the Pacific. The

${ }^{156}$ Ibid.

157 “Dr. Soyeda Says His Mission Is One of Peace,” Honolulu Star-Bulletin. May 19, 1913, 1. 
1898 Annexation of Hawaii by the United States facilitated the flow of Japanese people from Hawaii to the mainland. In the same way that former contract laborers chose to take up urban lifestyles in Honolulu, others continued to the mainland to pursue both urban and agricultural opportunities. The Anti-Alien Land Law restricted non-citizen, primarily issei Japanese from owning or leasing agricultural property beyond a three-year period. ${ }^{158}$ Acknowledging the connections between both mainland and local Japanese populations as well as national and Hawaiian politics, the Honolulu Japanese Chamber of Commerce and Japanese Merchants' Association focused tremendous efforts towards rights advocacy. Alongside such efforts, Japanese professional organizations engaged in community outreach to better integrate Japanese people and their businesses into local society.

The Japanese Chamber of Commerce contributed funds to community efforts and charities including the Free Kindergarten Association to better promote harmony within local society. On December 2, 1916, the Honolulu Star-Bulletin reported that "the members of the Japanese Chamber of Commerce have promised the kindergarten association they they will make individual donations." ${ }^{159}$ Members of the Japanese Chamber of Commerce had a strong record of civic engagement. After his arrival to Hawaii in 1916, former clothier and banker Taichi Sato joined the Honolulu Japanese Chamber of Commerce in 1922, simultaneously serving as a trustee for the $\mathrm{Nu}^{\text {'uanu }}$ Kindergarten, and president of the Robello School P.T.A. from 1927 to $1930 .{ }^{160}$ Ending

\footnotetext{
158 Ibid.

159 “Kindergartens to Receive Aid from Japanese,” Honolulu Star-Bulletin. December 2, 1916, 19.

${ }^{160}$ Henry P. Judd, Men and Women of Hawaii, 1954: A Biographical Encyclopedia of Persons of Notable Achievement, An Historical Account of the Peoples Who Have Distinguished Themselves Through Personal Success and Through Public Service. (Honolulu: Honolulu Business Consultants, 1954), 579.
} 
his extensive career with a year-long tenure as president of the Japanese Chamber of Commerce in 1941, Taichi Sato's personal engagement with academic organizations reflected some of the ways Japanese business owners provided for the community. The Japanese Chamber of Commerce, alongside individual business owners, contributed funds to community events including neighborhood festivals and carnivals. In December 1916, members of the Japanese Chamber of Commerce in concert with the Central

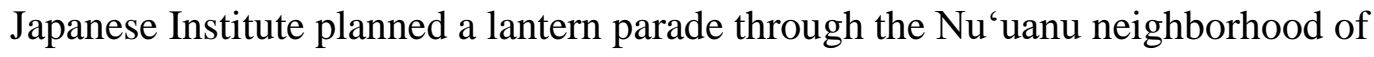
Honolulu in celebration of Oshogatsu, the Japanese New Year Festival. ${ }^{161}$ Beyond New Year's activities, the Japanese Chamber of Commerce also provided funds and entertainment to the annual Mid-Pacific Carnival during the same time period. ${ }^{162}$ Hamohamo residents hosted similar cultural outreach events, such as the bon odori activities hosted by Waikiki Aloha Kai. Both Harold Aoki and Masayuki Yoshimura noted the improved relations and understanding cultural events evoked. Masayuki noted that the Japanese language and culture school in Waikiki served as a meeting grounds for the neighborhood children, stating, “All the Japanese, all the Hawaiian boys, we go down there, talk story, get together...Some of the Hawaiian boys used to go Japanese[language] school with us. The family make 'em go Japanese school, some of them.”163 Harold Aoki noted that as his family store became more of a neighborhood staple, customers would spent some time to get to know his parents, stating, "Yeah. Because they used to keep on coming [to the store] even when I was five, six, seven, eight [years old]. Used to walk down, you see, to our store and stay in the store, chew the fat for some

161 “Japanese Will Offer Great Lantern Parade,” Honolulu Star-Bulletin, December 14, 1916, 5.

162 “What About the 1918 Mid-Pacific Carnival?” Honolulu Star-Bulletin, June 22, 1918, 1.

${ }^{163}$ Masayuki Yoshimura, 1460. 
time with my dad and my mother, you know. But other people just come buy and then gone, so we don't know.” ${ }^{164}$ While the support of large professional business organizations, such as the Japanese Chamber of Commerce did benefit the Japanese community-at-large, smaller local support groups, such as tanomoshi, or mutual financing organizations, provided much of the immediate support for individual shop owners who needed funding to launch their businesses.

During the early formation of Japanese-owned businesses in Hamohamo, Issei merchants utilized an informal, ad hoc system of mutual lending called tanomoshi when they wished to borrow money without the involvement of a bank or outside lender. Joining a tanomoshi gave an individual access to cash when they needed it. Tanomoshi first developed in rural Japan as a collective means of fundraising. British journalist J.W. Robertson Scott observed tanomoshi in practice amongst farmers in Tamagata Prefecture during his 1920s tour of Japan. Explaining that he encountered the term tanomoshi and $k \bar{o}$ used interchangeably, Scott described the practice with the following:

If a man is badly off or wants to undertake something beyond his financial resources, and his friends decide to help him, they may proceed by forming a $k \bar{o}$. A $k \bar{o}$ is composed of a number of people who agree to subscribe a certain sum monthly giving the first month's receipts to the person to succour (sic.) whom the $k \bar{o}$ was formed. Suppose that the subscription be fixed at a yen a month and that there are fifty members. Then the beneficiary - who pays in his yen with the rest - gets 50 yen. The monthly paying in and paying out continue for fifty months and all the subscribers duly get their money back, with the advantage of having had a little excitement and having done a neighbourly action. ${ }^{165}$

\footnotetext{
164 Harold Aoki, 733.
}

165 J.W. Roberston Scott, The Foundations of Japan: Notes Made During Journeys of 6,000 Miles in the Rural Districts as a Basis for a Sounder Knowledge of the Japanese People. (London: J. Murray, 1922), 184. 
The issei Japanese new arrivals to Hawaii made use of tanomoshi when they required financial assistance to achieve their goals. Toshio Yasumatsu recalled his experience using a tanomoshi when he purchased his business, Kapi ‘olani Cleaners. Of the experience, he stated, "We paid $\$ 2,000$ cash and $\$ 500$ by means of a tanomoshi, which they had in the old days, because they [the sellers] asked us to. So we brought the $\$ 500$ from the tanomoshi home and paid them." 166 Toshio bought the business from his former boss, a man he identified as Yanagitsubo. At the request of the seller, Toshio borrowed a portion of the money through a tanomoshi as a means to infuse money into the system. Though Toshio had the money to buy the business upfront, his participation in a tanomoshi ensured the overall health of the system which often suffered losses when a client failed to repay his or her debts. Recalling the risk one takes through participation in a tanomoshi, Toshio stated, “You can’t make money in tanomoshis. People can’t pay and it would go broke... One person would get into six or seven of them, and it would be fine to get the money, but when it came time to pay into it, if business became bad they wouldn't be able to and that's when it would go broke.” ${ }^{167}$ While participating in a tanomoshi provided money to applicants who may not have had access to loans from the traditional banking system, the risk it carried made it an unpopular option for its underwriters. As the English-language press gained awareness of tanomoshi, haole writers began to criticize the practice, contributing to its eventual disuse.

Official and semi-official criticism of tanomoshi stemmed from alleged abuses levied upon borrowers in the form of exploitative and exorbitant interest charges. A

\footnotetext{
166 Toshio Yasumatsu, 838.

167 Toshio Yasumatsu, 847.
} 
three-quarter page article in the April 26, 1909 Evening Bulletin described the tanomoshi system at length along, painting it in broad strokes as a money-generating scheme for lenders. ${ }^{168}$ The description provided by the local paper corroborated ones provided by J.W. Scott and Toshio Yasumatsu to an extent, but provided an additional detail that a member of the tanomoshi may put a bid on his stake to increase the likelihood of receiving money earlier in the lifetime of the mutual trust. The paper described an anecdotal example of a bidder offering a twenty-five dollar premium on a one-hundreddollar, ten-person tanomoshi, stating, "Assuming that [the bidder] has offered a premium of twenty-five dollars for the loan, and he being highest bidder, is awarded the same, he is paid in cash the sum of seventy-five dollars, his premium being deducted from the sum borrowed, and he then executes to each of his nine cooperatives a promissory note for the sum of ten dollars, payable in ten months." 169 Under the alleged scheme, the borrower owed a hefty penalty in interest on a devalued loan over its lifetime. As the article went on to point out, such a system violated the territorial law on usury, or the illegal lending of money at exploitative rates of interest. Passed by the legislature in 1905, any private citizen offering a personal loan at a rate "greater than two per centum per month, shall be guilty of usury.” ${ }^{170}$ The accounts provided by the Evening Bulletin and Waikiki residents conflicted over the application of premiums on tanomoshi in its typical practice. The author of the Evening Bulletin piece wished to decry the use of tanomoshi as a provincial habit and predatory scheme. However, as Toshio alluded, the practice provided money to

\footnotetext{
168 “Tanomoshi Ruins Japanese,” Evening Bulletin. April 26, 1909, 6.

169 Ibid.

${ }^{170}$ Laws of the Territory of Hawaii passed by the Legislature (Honolulu: Territory of Hawaii Legislature, Act 38, Session Laws, 1905), 72.
} 
issei resident who did not have access to, or had skepticism towards, the official banking system. By either account, the use of tanomoshi fell out of practice with time. By the 1931 establishment of the Waikiki Aloha Kai, Toshio recounted the rarity of the practice, stating, "By that time they did not use tanomoshis very much. It was something of the past to be asked to join [one]." ${ }^{171}$ Whether a force for the benefit or detriment to issei residents in need of a loan, the tanomoshi system represented a way for Japanese arrivals to conduct business without the involvement of an outside third-party. As Hamohamo businesses grew into neighborhood cornerstones, Japanese residents turned away from the practice, relegating it to the past.

The disuse of the tanomoshi system matched other discussed trends of cultural amalgamation between the Japanese and greater Hamohamo communities. As issei Japanese began to establish businesses in Hamohamo, the tanomoshi system allowed individual business owners the opportunity to receive a loan from the community when the borrower did not have access to the capitalist banking structure. Toshio Yasumasu recalled his participation in tanomoshis as a service to the community, noting that the practice held significant risk to all participants if one member could not repay his or her loan. Tanomoshi represented only one form of mutual support for Japanese business owners. The Japanese Chamber of Commerce and the Japanese Merchant Association held cultural events, hosted dignitary speakers, and donated money to the broader Hawaiian community in order to improve the reception of Japanese-owned businesses to the greater population. For their part, the Japanese proprietors worked well to cater to the hybridized tastes of their communities, offering options familiar within local culture,

171 Toshio Yasumatsu, 847. 
such as lau lau and pipi kaula (steamed pork in taro leaves and seasoned, aged beef respectively), but with Japanese additions, including shoyu (soy sauce) and rice. The resultant combinations and plate lunches remain staples of local cuisine, owing their popularity to the social and cultural comingling that occurred both on the plantation, and in working-class urban centers of Hawaii. 


\section{CHAPTER FOUR: STONEWALL GANG, BEACHBOYS, AND MULTIPLE MASCULINITIES}

Well, daytime, they were loafers. Lot of them were loafers, but lot of them worked. They hanged out on the Stonewall at night just because of music. And then, there were fights. You see, there were gangs in the different districts. Palama gang...And then, School Street gang. They were toughies. And Kaka'ako gang. They were another bunch of toughies. Each one of these places I named, districts, had football teams, too. But barefoot teams. They had different leagues with different weights. ${ }^{172}$

Hamohamo resident Joe Akana, 79, former beachboy and retired cargo specialist for Pearl Harbor Naval Shipyard

Native Hawaiian men and women, through haole-dominated print culture and tourist narratives, have received numerous depictions as sexualized bodies existing in subservient, inferior, or otherwise exploitable roles with respect to the tourist imaginary. In service to the burgeoning tourist industry, haole journalists and travel writers painted the young Native Hawaiian men of Waikiki as alternatively "the perfect servants” or “drunken derelicts" to draw lines of distinction between the two groups. ${ }^{173}$ Depictions of Native Hawaiian moral and constitutional inferiority aimed to further believed ideals of white morality and rationality, underscoring the latter group's purported natural position at the apex of Hawaiian society. By privileging the oral accounts of Native Hawaiian men who grew up in Waikiki over the biased, racist accounts offered by print media alone, this chapter aims to reconfigure gender and sexuality within the space of Waikiki along lines more sympathetic to its residents, capturing a complex image of the manifold

\footnotetext{
172 Joe Akana, oral history interview with 'Iwilani Hodges and Michi Kodama-Nishimoto, March 8, 1985, Hawai‘i Kai, O‘ahu. In Waikiki, 1900-1985: Oral Histories Vol. 1 (Honolulu: Center for Oral History, Social Science Research Institute, University of Hawai‘i, Manoa, 1986), 10.

173 Clayton Hamilton, “Honolulu Holds the Magic Mirror for Mankind.” Vogue, January 1, 1924, 56; “Allege ‘Gang’ Holds Sway at Waikiki Beach.” Honolulu Star Bulletin. June 1, 1916, 3.
} 
masculinities present and how they contributed to neighborhood dynamics including commerce, crime, and sexual interaction within tourist imaginary.

Over the course of the chapter, I follow the stories of Hamohamo neighborhood notables including Lemon "Rusty” Holt and Joe Akana through childhood to young adulthood analyzing their actions through the lens of masculinity and gendered expectations. From humor and horseplay of pranks played on tourists and Japanese neighbors and business owners to gang membership, territoriality, and protection and sexual access to “their” girls, expectations of masculinity for Native Hawaiian men diverged in marked ways from the docile, subservient, and feminized depictions they received in the press. As neighborhood hooligans grew into roles as beachboys who made their livings as cultural liaisons and professional tour guides to wealthy tourists, the young men honed their showmanship skills, professionalizing their sexualities. While beneficiaries of exotic, fetishized views upon their bodies by their clients, closer reading of beachboys’ personal accounts revealed their success as more than just "ladies’ men...during a time when American miscegenation laws prohibited men of color from marrying white women," ${ }^{174}$ as described by Walker. Relations between beachboys and their wealthy clients broke heteronormative as well as racial norms with wealthy men, including the Maharaja of Indore, lavishing gifts such as expensive clothes and companion travel to the mainland for exemplary service. In this way, wealthy men made souvenirs of the beachboys' bodies themselves, showcasing their favorite island experiences on living display at public events back home.

${ }^{174}$ Walker, Waves of Resistance, 58. 
The chapter closes with a reexamination of the tourist literature and periodicals that perpetuated views of white hegemony through sexualization and infantilization of Native Hawaiians and other nonwhites as inferiors. Analyzed in conjunction with the oral accounts of hotel magnate Richard Kimball, the combined evidence revealed that print depictions of Hawaiian and Asian inferiority match social practice amongst the white elite. Regarding the Japanese wait staff and household servants that surrounded him his entire life as natural children requiring constant education, Richard's experiences matched tourist fantasies of a Hawaii peopled by a genteel, yet simple 'native' population. The personal accounts of local residents, beachboys, and the haole elite revealed complex, multifarious manifestations of sexuality beyond the reductionist depictions of nonwhite docility and subservience gleaned from print media.

\subsection{Rascals of Waikiki and the Stonewall Gang}

Local rascals Lemon "Rusty” Holt and Joe Akana gave color to the Hamohamo neighborhood, spending their childhood days pulling pranks on the neighborhood shop owners, joining the ranks of the Waikiki beachboys as they grew older. Both men of Part-Hawaiian descent, their stories recorded the daily lives of Hawaiian families living near Hamohamo, capturing social gatherings, family members' occupations, and personal memories from the turn of the twentieth century through 1930s. Rusty Holt, born into the prominent Lemon family, recalled his family's ties to royalty through Queen Liliuokalani and Prince Kuhio. Growing up on the Lemon Estate, Rusty lived adjacent to the Queen's Hamohamo residence, and recounted his multiple encounters with her. Joe Akana, son of Chinese immigrant to Hawaii, Yim Kung Akana, lived across the Kukaunahi Stream 
from the Lemon property. As childhood friends, Akana and Holt shared memories of causing mischief together. As they grew older, they both participated as members of the Stonewall Gang, a group of neighborhood boys and young adults who participated in legal and illegal activities that included playing sports and brawling with other Honolulu area gangs. When in their home turf, sitting on the eponymous Stonewall on the Diamond Head end of Waikiki Beach, the Gang passed time entertaining tourists, diving for fish and singing songs for money. Joe Akana recounted his transition from gang member to legitimate beachboy. The beachboy served as a tourist's guide to Waikiki entertainment. Akana’s stories highlighted the beachboy's multifaceted role as entertainer, tour guide, and concierge as he catered to guests' tastes, using his personal connections to improve their vacation experiences.

Born on the Lemon Estate in Waikiki on September 22, 1904, Rusty Holt experienced Waikiki's early transitions firsthand. The third child of seven born to Augusta Helen Lemon Holt and Edward Holt, Rusty had Hawaiian ancestry through his mother's side. In the 1890s through the turn of the century, Rusty's maternal grandmother, Mary Ann Wond Holt, headed the Kapi`olani Maternity Home for women of Hawaiian decent at the behest of Queen Kapi`olani herself. ${ }^{175}$ The Lemon family’s close connection to royalty allowed them to buy property adjacent to Queen Lili‘uokalani’s Hamohamo property. The one-acre estate shared street boundaries with Kalakaua, Paoakalani, and Kapahulu Avenues, and Lemon Road, which still today bears the family's name. Rusty's memories of entertaining royalty hinted to his family's importance. Queen Lili'uokalani made occasional visits to his grandmother, the two

\footnotetext{
${ }^{175}$ Rusty Holt, 778.
} 
having been classmates at the Royal School. ${ }^{176}$ Rusty recalled the Queen's preference for haohao (soft and young) coconuts and small fish and other reef edibles. Of her visits, he stated:

Also, I had to go out to the stone wall, in the front of the stonewall [at Kuhio Beach], dive and catch three or four, or five, or six manini (convict tang fish). You know what a manini fish is? She liked manini. She ate them raw. I also had to go out to near Queen's Surf arid dive for wana (sea urchin), plenty of wana there, bring that home then go back out to Queen's Surf and dive for lipoa, limu (two types of seaweed). She liked lipoa! And my grandmother, in the meantime, would be cooking Hawaiian stew. And that's what she had, whenever she came. ${ }^{177}$

The stone beach wall defined the geography of Waikiki Beach, forming the terminus of the beach on its Diamond Head end. The wall formed a groin protecting Kuhio Beach from oncoming surf. The calmness of this portion of the beach made it an ideal swimming spot and gathering place for the neighborhood's children. Rusty recalled that in the mid 1920s, he and other members of the Stonewall Gang would spend their days in the waters by the wall “diving for nickels” from tourists. Of the activity, he stated:

When the tourists came, we would take off our tights dive into the water, and come up with manini, one or two manini, showing the tourists that we were catching the fish with our tights. We'd hold it up, and if the tourists dropped a nickel, we turned around, we didn't have any tights on and we showed them our 'Okoles (behinds). When they dropped a quarter, we thanked them and did not show them our 'Okoles. That, we did right along all (the) time. Those were the days of "dive for nickels" they call it. ${ }^{178}$

The arrival of tourists from the steam liners Matsonia, Lurline, and Claudine provided Rusty and his friends with targets for their shenanigans. Their behavior exhibited a willingness to take advantage of tourist imaginations of local children as helpful, yet

\footnotetext{
${ }^{176}$ Harold Morse, “Obituaries: Rusty Holt, 94, avid sportsman, deep local roots.” Honolulu Star Bulletin. March 20, 1999.

177 Rusty Holt, 783.

${ }^{178}$ Rusty Holt, 805.
} 
economically disadvantaged. Showing rudeness to the white newcomers allowed Native Hawaiian children the opportunity to up-end the racial hierarchy, exerting their place ahead of the haole tourists. However, with mainland tourism still in its infancy in the days prior to the reclamation of Waikiki and the later opening of the Royal Hawaiian Hotel, neighborhood shop owners fell victim to the majority of Rusty's pranks.

Pulling pranks allowed Part-Hawaiian boys to exhibit their masculinity and establish their social dominance over both haole tourists and other nonwhite neighbors. Rusty Holt's memories of playing tricks on the local Japanese shopkeepers provided a clear image of racial and physical layout of the Hamohamo neighborhood. He recalled that the intersection of Paoakalani and Kalakaua Avenues formed the nucleus of the commercial district. His uncle, Jimmy Lemon, owned a beer shop there adjacent to the first location of the Aoki Store. Continuing down Kalakaua from the Aoki Store, Rusty remembered a barbershop and a laundry cleaner. Both Rusty and Harold Aoki had fond memories of the first-generation Chinese man who ran the laundry. Rusty recalled him as "Old Man Tailor," who provided laundry service for the linens from the Moana and Seaside Hotels. Both Holt and Aoki remembered having a congenial relationship with him. On Harold Aoki's end, he remembered leaving his family's store for most of the day to spend time with Tailor, eating manapua (Hawaiian-style pork buns). Rusty Holt, famous for his mischievous pranks, recalled Old Man Tailor as the only Waikiki shop owner who treated him kindly. One prank involving both the Aoki Store and Old Man Tailor, however, left Holt feeling guilty. In preparation of instances when he might need to punish someone who had crossed him, Rusty collected duck eggs from his neighbors' 
ponds and buried them in his yard for months, letting them rot in their shells. One day,

Harold's mother, Mrs. Aoki, had one way or another warranted Rusty's wrath:

Well, about that time Mrs. Aoki was giving me a bad time. I wanted crack seed (Chinese dried fruit) and no way, could I get it. So that went on for quite a few days. Then I decided that, "All right, old 1ady, you're gonna get it this time." So I got a bunch of those eggs, ripe duck eggs, got on the streetcar and as we went past Aoki's, I started letting them go. Unfortunately, I missed Aoki's. I missed the clothes cleaning shop. I missed the barbershop, and the eggs went right into my good, good friend's laundry shop. It splattered rotten duck eggs all over the place. I don't know. I felt worse than anybody, I guess, because I had done something to a person who 1iked me and I 1iked him. So much for duck eggs.

Rusty's actions underscored his perception of entitlement to service from Mrs. Aoki, which he enforced through the punishment of mean-spirited pranks. Rusty's penchant for pranks marked only one way local children committed crimes in the Hamohamo neighborhood. The Stonewall Gang received notoriety not only as jovial beachboys, but for their roles in petty crime and fights with other Honolulu neighborhood gangs.

Hamohamo and Kalia residents both recalled the importance of belonging to a gang to the social lives of neighborhood boys and young men. Joe Akana and Louis Kahanamoku, members of the Stonewall and Kalia Gangs respectively, both remembered sport activities and fighting being organized along neighborhood lines. Of the Stonewall Gang, Joe Akana reflected:

Well, daytime, they were loafers. Lot of them were loafers, but lot of them worked. They hanged out on the Stonewall at night just because of music. And then, there were fights. You see, there were gangs in the different districts. Palama gang. I could name individuals from all these different gangs. Like Kalihi, they had Frank Kana'e...And then there was the Palama gang who had a lot of members that indulged in sports. Palama Settlement, you know, they played basketball, football, everything. And then, School Street gang. They were toughies. And Kaka'ako gang. They were another bunch of toughies. Each one of these places I named, districts, had football teams, too. But barefoot teams. They had different leagues with different weights. ${ }^{179}$

179 Joe Akana, 10. 
Representing your neighborhood carried significance and pride to the young men who participated in gangs. While some neighborhoods focused on organized sports as their primary social activity, gangs from working-class neighborhoods prided themselves on their ability to fight. Louis Kahanamoku, younger brother of famous Olympian and waterman Duke Kahanamoku, corroborated Joe Akana’s view of neighborhood sporting events devolving into fights:

We played a little baseball. You know, we choose up [sides]. Get different districts. Kalia, you go out and played that bunch, the Stonewall Gang. And then we had another bunch go play the gang up in Kalihi. But us, we want to play the tough guys. Kalihi and Kaka'ako, guarantee going to be a fight, so we want to get in it. ${ }^{180}$

Gang members also had the responsibility of protecting their home turf from outsiders.

For members of the Stonewall Gang, fighting drunken soldiers from nearby Fort

DeRussy proved an important task. They saw the service members who frequented Waikiki bars and nightclubs as threats who "sometimes got nasty with our girls."181 Rooted in hyper-masculine views of women as both sexual conquests and objects needing protection, tensions between soldiers and Waikiki locals resulted in physical altercations on a regular basis. A May 1915 Hawaiian Gazette article reported that the Honolulu Mayor spoke at Fort DeRussy after soldiers interrupted a luau he had hosted in Kapi`olani Park in an incident that resulted in fighting. ${ }^{182}$ In response to Army officials’ objection to the use of police force in this incident, the Mayor stated, "There was

${ }^{180}$ Louis Kahanamoku, oral history interview with Warren Nishimoto, May 20, 1985, Keauhou, Kona, Hawai'i. In Waikiki, 1900-1985: Oral Histories Vol. 1 (Honolulu: Center for Oral History, Social Science Research Institute, University of Hawai'i, Manoa, 1986), 857.

${ }^{181}$ Joe Akana, 11.

182 "Order of Mayor as to Soldiers Causes Trouble," Hawaiian Gazette, May 7, 1915, 8. Fort Derussy was an army barracks on the Kalia end of Waikiki at the time. The land remains part of the U.S. Army recreation facility in Waikiki today. 
widespread curiosity about the luau and even after the courses had been served, I knew we ran the danger of being overrun by the whole town if a line was not drawn and the police given orders to see that it was not overstepped." ${ }^{183}$ Even the city Mayor noted animosity between Waikiki’s Hawaiian and military populations when he made provisions to host a luau honoring notable Hawaiian residents. While police authorities in the aforementioned incident favored local Hawaiians over mainland arrivals, typical media views of Hawaiian youths adopted negative conations.

The Honolulu Star-Bulletin first recorded gang activity on Waikiki Beach in 1916, citing an altercation between Waikiki local Archie Boyd and tavern manager George H. Willey. Prosecuting Attorney Frank Thompson rebuked the rise of violence on the beachfront, stating, "New York has the Bowery; Chicago, Detroit, San Francisco, all have their tough places, and that's what a certain gang is trying to make out of Waikiki Beach. There is a bunch of drunken derelicts like 'Steamboat Bill' and 'Tough Bill' that needs cleaning out. Their very names suggest their character." ${ }^{184}$ The Prosecuting Attorney released this statement following the trial's guilty verdict. The article pointed to the defendant's character flaws, cursing in the presence of women and breaking his drinking glass at the bar when the altercation occurred, to incite moral panic. While Waikiki residents did admit to participating in gang fights, the account in the StarBulletin exaggerated the situation, linking one instance of public drunkenness to broader 'gang’ phenomena. The Prosecuting Attorney exhibited a prejudice against two characters he identified as "Steamboat Bill” and "Tough Bill.” Brothers Daniel and

${ }^{183}$ Ibid.

184 “Allege ‘Gang’ Holds Sway at Waikiki Beach.” Honolulu Star Bulletin. June 1, 1916, 3. 
George Keaweamahi went by the the names "Steamboat” and “Tough” Bill, respectively, and multiple oral history accounts from Waikiki residents recounted fond memories of the two men. ${ }^{185}$ Known for their large stature and kindness, the Keaweamahi brothers served as lifeguards, early beachboys, and founding members of the Hui Nalu Surf Club. A 1918 Hawaiian Gazette article entitled, "Keaweamahi Adds to His Collection of Lives Saved at Beach,” praised "Steamboat Bill” for saving the life of a nineteen-year-old young man caught in dangerous surf. ${ }^{186}$ Kalia resident Mary Clarke recalled community fishing trips where her brother and "Tough Bill” would catch fish and distribute it to area families. ${ }^{187}$ The depiction of the Keaweamahi brothers in the Star-Bulletin did not match their likeness according to their closest friends and neighbors, suggesting the sensational, and perhaps racialized, nature of coverage of Waikiki beachboys in the local press. Of interesting note, no mention of Archie Boyd, the original subject of the newspaper article and defendant in the Waikiki assault case, appeared in any of the fifty-one oral history accounts. Linking an isolated case of violence to character attacks against the Keaweamahi brothers affirmed the Prosecuting Attorney’s negative view of Waikiki beachboys. Hamohamo resident Joe Akana shared his experiences growing up with the Stonewall Gang, detailing his transition to full-fledged beachboy.

${ }^{185}$ Ah Buck Yee, oral history interview with 'Iwilani Hodges, June 2, 1986, Waikiki, O‘ahu. In Waikiki, 1900-1985: Oral Histories Vol. 1 (Honolulu: Center for Oral History, Social Science Research Institute, University of Hawai 'i, Manoa, 1986), 1024; Ernest Steiner, oral history interview with Michi Kodama-Nishimoto, March 5, 1985, Honolulu, O‘ahu. In Waikiki, 1900-1985: Oral Histories Vol. 1 (Honolulu: Center for Oral History, Social Science Research Institute, University of Hawai‘i, Manoa, 1986), 85. 1918, 3.

186 “Keaweamahi Adds to His Collection of Lives Saved at Beach,” Hawaiian Gazette. July 2,

${ }^{187}$ Mary Clarke, 638. 
Born on May 4, 1907 in his family’s home on ‘Ohua Lane, Joseph Yim

Ka'imu'iole Akana grew up surrounded by members of the Stonewall Gang, participating in shenanigans with his friend Rusty Holt. ${ }^{188}$ Similar to his friend, Joe Akana had Hawaiian ancestry through his mother, Martha Akeo Nawahine of Waihe'e, Maui. His parents met on Maui where his father, first-generation Chinese immigrant Yim Kung Akana, worked on a sugar plantation for the Baldwin family. The youngest of eight children, Akana remembered living in a busy house. In his interview with 'Iwalani Hodges, he lamented on how the construction of his house lent itself to being a social center for the community. The house had a wraparound lanai that extended thirty feet in the back. His older brothers invited their friends from the Stonewall Gang for evening dances on Saturday nights:

All right. You see, here's the lanai, and the entrance over here. You used to walk out on the steps, then you turn this way, and you're walking into this lanai. Now, this lanai was only half the width, that I just mentioned. But after these guys [JA's brothers] grew older, David and Charlie--Charlie's the one who worked for Hawaiian Dredging. He just died. When they grew older, you know, they used to go to dances and things like that, but they decided they want to have dances at home. They had a gang in Waikiki. The Holt Brothers-- Melvin, Elmer--and Leslie Lemon. Boys that hung out at Stonewall at night. They had their own gang. They used to hire orchestras, you know. When the saxophones came in, it was a novelty, then. And when the drums came, it was another novelty. To you, it's just like nothing now, but at that time it was a novelty, oh God. So they hired the orchestras, their gang, and they had dances. Almost every Saturday night in the summer! Oh, God, these guys. ${ }^{189}$

Music played an important role to the image of the Stonewall Gang. Younger than the core group that made up the gang, Joe Akana did not consider himself a full member, but he recalled many of the groups songs, of which he performed his own renditions during

\footnotetext{
188 Joe Akana, 2.

189 Joe Akana, 8.
} 
his beachboy days. ${ }^{190}$ Joe Akana's childhood memories of running around with the Stonewall gang corroborated aforementioned descriptions of the district. His family home on the intersection of Kalakaua Avenue and 'Ohua Lane, Akana recalled living behind the Aoki Store. He also recalled the stream the separated his house the the Lemon Estate. Both Joe Akana and Rusty Holt had memories of a particular Chinese dim sum vendor who used to walk through the area, selling his wares. Joe mentioned only how he enjoyed eating the manapua (Hawaiian-style pork buns) he sold. Rusty provided the details of how they acquired them:

We had one man, old Chinese man, and I can't think of his name. I should remember it because I was his first, best, illegal or legal customer. Joe [Akana] and I---he carried two baskets on a stick in the middle--one basket in the one basket in the front and also a can, a five-gallon or ten-gallon can. In those containers, there was black sugar manapua, hash, and one or two other items. Joe would talk to him a point to the front basket. While the old man was talking to Joe about the front basket, I would be in the back helping myself and stuffing things, all I could stuff, into my pockets. ${ }^{191}$

The merchants and street vendors of Kalakaua Avenue provided Rusty and Joe Akana with ample opportunities for pranks and entertainment, if illegal. While Rusty Holt moved from Waikiki shortly after finishing high school at Kamehameha School to serve as Postmaster in Kahului, Maui, Joe Akana built on his childhood experiences with the Stonewall Gang as a successful beachboy and member of Hui Nalu.

First-hand accounts gleaned from Joe Akana, Rusty Holt, and other members of the Stonewall Gang developed a view into the diverse masculinities in youth male culture in Waikiki. By playing pranks that bordered on petty crimes against haole visitors and

190 See Joe Akana, 49-57 for transcripts of songs he performed as a beachboy; Rusty Holt, only three years older than Joe Akana, considered himself one of the Stonewall Gang.

${ }^{191}$ Rusty Holt, 789-790. 
Asian immigrant neighbors, Rusty Holt aimed to demonstrate his superiority against a racial hierarchy that otherwise place white Americans at its apex. Within circles of sameage peers, Waikiki boys organized themselves into neighborhood gangs, vying for superiority through sports and fighting. When it came to interracial conflict, Native Hawaiian men competed with white American soldiers for sexual access to women, declaring a need to "protect” perceived fragile femininity. In press crime reporters vilified Waikiki neighborhood gang members as “drunken derelicts” and disdainful characters in opposition to oral accounts that treat the same men as local heroes and positive influences on their communities. As neighborhood gang members including Joe Akana, Louis Kahanamoku, and “Tough Bill” Keaweamahi matured, their affiliations transitioned from such youth organizations to the Hui Nalu Surf Club, an organization for Native Hawaiian surfers and watermen founded in 1911. Beyond protecting Native Hawaiian interests on the waves against the encroachment of the whites-only Outrigger Canoe Club, Hui Nalu organized beach concessions for the hotels along Waikiki Beach. As surf instructors, musicians, and guides to outdoor activities and nightlife, Hui Nalu members served as Waikiki’s first and preeminent beachboys.

\subsection{Hui Nalu, Beachboys, and Sex Appeal}

In resistance to white hegemony within the political and social establishments of Hawaii, Native Hawaiians and other nonwhite peoples formed organizations that promoted and protected their individual rights and interest. Similar to the Japanesefounded social organizations discussed in the previous chapter, such as Waikiki Aloha Kai and the Honolulu Japanese Chamber of Commerce, Native Hawaiians organized 
social bodies as well. Isaiah Helekunihi Walker recognized Hui Nalu as a surf- and beach-oriented extension of the Hui Aloha 'Aina and Hui Kalai'aina resistance movements born out of anti-Republican and anti-annexation sentiments that arose following the January 17, 1893 overthrow of the Hawaiian Monarchy. ${ }^{192}$ In the same fashion that the two political organizations resisted white encroachment through petitioning U.S. annexation, Hui Nalu represented Native Hawaiian rights and access to the waves at Waikiki Beach. In concert with Haunani-Kay Trask and Noenoe Silva, Walker highlighted Hui Nalu’s activism as evidence of Native Hawaiian resistance to colonialism in contrast with the dominant racialized portrayal of Hawaiian men’s passivity. ${ }^{193}$ Through the lens of anti-colonial resistance, Walker developed a narrative that captured Hui Nalu men as ideal models of masculinity, successful in their sexual pursuit of wealthy white women on the beach in ways they could not achieve further inland. Coining the phrase "ka po'ina nalu" for the surf zone, Walker looked at the space as a cultural borderlands, or “boarder-lands,” where Native Hawaiian masculinity dominated those of haole men. ${ }^{194}$ The section will investigate the sexual success of Hui Nalu's beachboys in further depth, exposing rather than a single, heteronormative Native Hawaiian masculinity as revealed by Walker, multiple masculinities wielded by Waikiki beachboys with success, appealing to men and women clients.

Joe Akana began making money on the beach at the age of fourteen. He failed to complete high school due to his playing hooky on days he knew the steamships would sail in. He noted that tourists paid money for every display of talent. Just as Rusty Holt

\footnotetext{
192 Walker, Waves of Resistance, 5.

193 Trask, 53; Silva, 7.

194 Walker, Waves of Resistance, 55.
} 
dove for nickels, Joe Akana learned to perform for tourists. Climbing coconut trees and providing swimming lessons brought in modest money, but Akana recalled that taking groups of tourist out on the water in an outrigger canoe brought in the best money:

Surfboard instruction, swimming, canoeing--taking people out in the canoe. Made a few bucks. Could make as much as five dollars a day. Oh, boy-, was that big money. Because sometimes, you only make about two dollars, three dollars, but that was good. Because in those days, it was a dollar a passenger for a canoe ride. We go out and catch three waves. But we fill the boat up with as much as six paying customers. Six dollars. The house was [Edward] "Dudi" Miller, the owner of the canoe. He had his cut. And the captain out of six passengers, he got dollar and a half; and the second captain got dollar and a half. When I first started, I was second captain. That meant two boys--two skilled boys--went in the canoe with six paying passengers.

The formula of two beachboys guiding a crew of haole tourists over the waves proved a consistent and successful one. In a 1920 Los Angeles Times piece on Waikiki, a journalist recounted his experience outrigger canoeing. Of the experience, he stated:

There is a native in the prow to paddle and another in the stern to steer and when they get the canoe about half way over to San Francisco, suddenly they decide to turn around and let the sportive billows play tag with helpless you. From long years of experience these natives know just when and where to make this turn, and best of all, they know how to do it. ${ }^{195}$

The author's language revealed his paternal fascination with "native” culture. The travel writer imagined his beachboy guides living an idyll spent honing their canoeing skills to provide for their livelihoods. However, for Joe Akana, giving canoe tours represented a quick way to make a dollar while skipping class. While visitors developed imaginary notions of Hawaii as a timeless land immune to the ravages of modernity, they provided opportunities for local beachboys to participate in the modern tourist economy. As the hotel scene in Waikiki developed into the 1930s, young men such as Joe Akana shifted

195 “Truth About Waikiki Beach,” Los Angeles Times. June 6, 1920, 32. 
their attention from participating in petty neighborhood fights to becoming professional entertainers in their own right.

The life of a Waikiki beachboy required knowledge of showmanship as well as skills on the water. As such, the famous Hui Nalu Surf Club formed to protect Native Hawaiian and other nonwhite locals' interests on the beach which included securing access to surf breaks and monetizing members’ interactions with visitors. ${ }^{196}$ Developing their business skills as tourism bloomed in the later 1920s and into the 1930s, Hui Nalu members branched out from providing beachfront concessions into more immersive, and expensive, tour experiences. Louis Kahanamoku recalled that the hustle began before the new arrivals even made it to the beach:

Us boys would go down the ship. And we'd buy leis for them. Was thirty-five cents a lei or fifty cents. But we just buy 'em. We come out with arms full of leis, and we put 'em on the tourists that hang around the hotel beaches. We come out of there, twenty, thirty, forty bucks by the time we got out, put (chuckles) leis on. ${ }^{197}$

Buying flower leis for the new arrivals not only netted a large profit for the beachboys upfront, but allowed them to identify wealthy, high-paying potential patrons based on the amount they tipped and the level of interest they had in the local's services. From their clubhouse on the beachfront of the Moana Hotel, Hui Nalu members attracted the attention of their patrons. In most cases, individual beachboys offered their services to entire families. Joe Akana remembered working for the Honeyman family every summer for five years in the 1930s. He recalled that the Honeymans would ship over two

${ }^{196}$ Please read Isaiah Helekunihi Walker, "Hui Nalu, Beachboys, and the Surfing Boarder-lands of Hawaii” The Contemporary Pacific 20, No. 1 (2008) and Waves of Resistance: Surfing and History in Twentieth Century Hawaii. (Honolulu: University of Hawaii Press, 2011) for thorough discussion of the 1911 founding of Hui Nalu. Pioneering surf and watersport legends Duke Kahanamoku, William "Knute" Cottrell, Kenneth Winter, Edward Kaleleihealani "Dudi” Miller founded the club in 1915 in opposition to the exclusively-white Outrigger Canoe Club.

${ }^{197}$ Louis Kahanamoku, 871. 
Cadillacs for their use while on the island. Joe had the clearest memory of Bob, the oldest son, with whom he spent the most time. Of the son, he stated, "He went out with me. He'd come down with two Cadillacs every year. Two Cadillacs. And I used one. Just he and I. And the father, and the wife, and the daughter used the other one. But Bob and I used one Cadillac for just he and I.” Joe Akana's had exclusive contact with the Honeyman's son in order to serve as a masculine role model for the young man. Viewed as a knowledgeable and skilled waterman, Joe's time with the boy served as a mentorship for the uninitiated visitor. Spending weeks with a single family netted beachboys their best pay. Multiple beachboys recounted that clients often employed them to entertain their daughters, specifically. ${ }^{198}$ Beachboys varied on their memories of sexual activity with their clients. At one extreme, Louis Kahanamoku insisted that sexual intercourse proved central to his interactions with haole women. On the other, Joe Akana insisted that he gained his clients' trust by establishing a policy of "No rough stuff." 199 The two men having different interviewers could account for their differing admission to sexual activity with clients. Louis Kahanamoku could have felt more comfortable revealing, or even bragging, about his experiences with Warren Nishimoto, a man. Joe Akana may have felt the need for humility when discussing his with 'Iwilani Hodges, a woman. In either case, sexual attraction helped sell the image of the beachboy to willing clients.

198 Joe Akana, 19; Louis Kahanamoku, 872; Turkey Love, oral history interview with 'Iwilani Hodges, May 14, 1985, Hawai'i Kai, O‘ahu. In Waikiki, 1900-1985: Oral Histories Vol. 1 (Honolulu: Center for Oral History, Social Science Research Institute, University of Hawai 'i, Manoa, 1986), 1691.

${ }^{199}$ Louis Kahanamoku, 863; Joe Akana, 46. Isaiah Helekunihi Walker removed this phrase from his transcript of Akana's interview in "Hui Nalu, Beachboys, and Boarder-lands," 2008 on pp. 99. The full quote worked counter to his argument that beachboys used sex as a main selling point of their services to haole women. 
Beyond one-on-one interactions with clients on the beach, beachboys performed as actors and musicians as part of the burgeoning nightlife scene.

To improve their sexual appeal to mainland tourists, members of Hui Nalu performed on stage and off as actors and musicians, affording themselves critical praise. In February 1914, the Star-Bulletin theater critic provided a review of a burlesque variety show performed by Hui Nalu in conjunction with the Kilohana Art League in Waikiki. ${ }^{200}$ The club produced and staged the show in order to raise funds to build their first clubhouse on Waikiki Beach. Consisting of four acts, the play showcased beachboy legends “Dudi” Miller, George “Tough Bill” Keaweamahi, and even then-famous Duke Kahanamoku "dressed—or undressed" in fanciful costumes, displaying their athletic prowess and showmanship in various bits requiring their ability to sing, dance, and even dive into an on-stage pool. ${ }^{201}$ The reviewer gave praise, if surprised, to the ensemble of champion swimmers and watermen who proved to have decent voices and acting skills. The show elicited a provocative response in the critic, who omitted full description of the show's racier scenes, but gave illusion to its content through describing a subsequent scene which featured "a bevy of pretty and handsomely dressed girls and correct young men in evening clothes.”202 The author's comments implied some level of cross-dressing having occurred in the show, in accordance with its proclaimed burlesque nature. In this way, Hui Nalu beachboys circumvented traditional gender roles on the stage to augment their sex appeal. With Hui Nalu drawing its ranks from the aforementioned Kalia and

200 "Hui Nalu Show Riotous Fun with Mirth, Music and Dancing,” The Honolulu Star-Bulletin. February 12, 1914, 5.

${ }^{201}$ Ibid.

202 Ibid. 
Stonewall Gangs, it followed that musical talent played a central role to the beachboy image. Joe Akana, later a Hui Nalu member himself, recalled the founders of the club gathering every Sunday on the Moana Pier in the early 1920s to play music. Of the Sunday night jams, he lamented, “Oh, beautiful, beautiful. You know, when the moon was up and the pier music was going on, oh God. When the thing broke up at night, when it was all over, one beach boy, he went this way, one went this way with his wahine (woman), and they all go in their different directions." ${ }^{203}$ Joe's remarks captured the intertwined nature of beachboy musicianship and sexuality. Whether on stage or on the beachfront, Hui Nalu members used their performance skills in attracting women and men potential clients.

Top performing beachboys received the benefit of high-paying clients who rewarded their guides with lavish presents and trips to the American mainland. Joe Akana recounted such travel during his employment with the Maharaja of Indore after his ascendancy to head beachboy and leader of Hui Nalu.

Perhaps Joe Akana’s highest profile client, the Maharaja of Indore took the beachboy into his confidence, awarding him the position through his superior performance and business acumen. Sir Yeshwant Rao Holkar, the Maharaja of Indore and then the richest man in the world sent sail from Los Angeles for Honolulu on October 12, 1936 as part of a year-long tour of the United States. ${ }^{204}$ A Los Angeles Times article announcing his departure from San Pedro Harbor aboard Matson’s Lurline steamer waxed on his "smartly clad" figure and his "clipped, crisp Oxfordian accent."” ${ }^{205}$ A ruler

\footnotetext{
${ }^{203}$ Joe Akana, 20.

204 "Maharajah of Indore Sails for Honolulu," Los Angeles Times. October 12, 1936, A1. ${ }^{205}$ Ibid.
} 
of a princely state of British India, the Maharaja finished his education at Christchurch, Oxford. Joe Akana made note of his benefactor's scholarly pedigree in his memories of the young ruler. He recalled that Bert Oglivie, then the manager of the Royal Hawaiian Hotel introduced him to the Maharaja shortly after the dignitary's arrival, stating:

Managers from both the Moana and the Royal Hawaiian [Hotels], they like me. I mentioned this to you. Like the Maharajah of Indore, when he came with his party of seventeen, he didn't know who to select as a beach boy. So Bert Ogilvie who managed the Royal [Hawaiian Hotel] at that time, he called me.

"Joe, you take care of the maharajah."

There was seventeen in the party. I could only take care of he and his wife. But I picked certain boys out of the [Hui Nalu] club to take care of his party. The maharani had her guests; he had his guests. And they had like his aide-de-camp and her lady-in-waiting, things like that, you knew, that made up the whole party. ${ }^{206}$

Joe Akana had earned the trust of the manager of the Royal Hawaiian through his reputation as a first-class beachboy. As he did with the Honeyman family, Joe Akana gave his highest-profile clients his complete attention, taking no other clients during the Maharaja’s stay. Using connections Joe Akana made through Bert Oglivie, the beachboy set the itinerary for the Maharaja, his wife, and their retinue of servants and associates. Beyond providing the standard array of beach concessions, including surf lessons and outrigger canoe trips, Joe Akana provided for the the Maharaja's transportation and accommodation to downtown Honolulu's restaurants and shops. The cashier's office at the Royal Hawaiian Hotel gave Joe an open line of credit and cash to ensure that the Maharaja and Maharani did not worry about any expenses until the conclusion of their stay. Of his time with the couple, Joe Akana recounted:

I kept track of everything spent. I made his inter-island itinerary and things like that. They'd go to the different islands. I was the only guy who could ride the same automobile or ride the same elevator with them, the couple. The

${ }^{206}$ Joe Akana, 18. 
[Maharaja's] aide-de-camp and the secretary couldn't ride the same elevator with them. ${ }^{207}$

His role as tour guide gave Joe Akana exclusive access to the Maharaja and Maharani in ways that even his closest advisors lacked. The services Akana provided transcended those typically requested of beachboys from the time. The positive connection he formed with the Maharaja prompted the affluent ruler to request Joe Akana follow him on his return trip to Los Angeles as part of his tour party. Affluent clients often treated beachboys to mainland trips as a form of souvenir taking. Prized for their toned bodies and exotic features, beachboys like Joe Akana provided the parties of wealthy patrons a degree of social cachet. No stranger to the press, the Maharaja collect new members of his retinue as he travelled to new locations as a means of attracting the public's attention. The Maharaja’s adventures represented a continuous, moveable festival, which Joe Akana joined in Waikiki and followed to Los Angeles.

Joe Akana’s presence in the Maharaja's retinue demonstrated the Indian ruler's wealth and desire to surround himself with notable and intriguing people. After a month's stay at the Royal Hawaiian in Waikiki, the Los Angeles Times reported the Maharaja's return to Southern California in November, 1936. ${ }^{208}$ His plans to visit San Diego and stay at the Hotel del Coronado came undone after he and his wife became ill. As a result, they remained in Los Angeles longer than expected, into December. Joe Akana recalled parts of the affair. In particular, he remembered the live-in nurse the Maharaja picked up over that trip, stating:

I got to tell you that the maharajah was sick in L.A., and when they went to Miami, he took his nurse with him. Then from Miami they went to New York to

${ }^{207}$ Ibid.

208 “Maharajah Expected at San Diego,” Los Angeles Times. November 9, 1936, A6. 
meet their daughter who was only about five years old with her amah or whatever. From New York, they went to St. Moritz, Switzerland. All this time, his nurse was with them. But while they were in St. Moritz, [the Maharani] developed TB [tuberculosis] and she died there.

In his interview, Joe Akana noted that the ailing couple’s nurse, Margaret Lawler, went on to marry the Maharaja two years following the Maharani’s death. Like Joe, Margaret had caught the eye of the Maharaja as an exotic object the ruler wanted beside him. Proximity to the Maharaja gave Joe Akana access to initimate details of the ruler's life and wellbeing. The beachboy shared information on the couple's health of which the press had only limited knowledge. A Los Angeles Times revealed only that the Maharaja was "ill with a cold" when he announced that he had cancelled his plans to continue south to recuperate at the home of Hollywood actress, Gail Patrick. ${ }^{209}$ Through his proximity to the couple, Akana knew that their health suffered more than they revealed to outsiders. Joe Akana’s inclusion in his clients’ entourage even after the couple left Hawaii followed the experiences had by other beachboys. In his own interviews, Alan “Turkey” Love recalled the frequency by which he accompanied clients back to the hometowns on the U.S. mainland.

Junior to Joe Akana by twelve years, Alan “Turkey” Love recounted frequent travel to the U.S. mainland as a perk of working as a beachboy in the age of air travel. Turkey Love began his beachboy career in earnest upon his graduation from high school in 1938. Impacted by the cessation of civilian tourism with the onset of World War II, Turkey did not see his most successful years as a beachboy until after the war. ${ }^{210}$

209 “Cold Will Keep Maharajah Here Another Week,” Los Angeles Times. November 22, 1936, A1.

210 Turkey Love, 1667-1668; In his interviews, Alan “Turkey” Love revealed that he left the beach in 1941 to work in the dry docks at Honolulu Harbor before being drafted into the U.S. Army. He served three years in the army stationed at Schofield Airfield in Wahiawa, Oahu, Hawaii. 
Technological advancements in air travel, developed as a result of the war effort, increased its popularity as a method for arrival for visiting tourists. Pan American Airways helped usher in this new age of travel through the employment of new Boeing 377 Stratocruisers that cut in half the once-eighteen-hour trans-Pacific flight from San Francisco and Los Angeles to Honolulu. ${ }^{211}$ The airline's first concepts for rapid air travel to Hawaii arose in 1940, with Pan American Airways President Juan T. Trippe pronouncement for a plane capable of stratospheric travel "considerably more powerful and much faster than the Boeing clipper ships we are now flying over the Atlantic and Pacific Oceans.”212 Wartime needs for a long-range heavy bomber provided the company with the needed technology with the development of the B-29 Superfortress. As often the case, the tools of warfare found applications in both leisure and the further cultural colonization of liminal locales. By 1949, Pan American employed eight Superfortress-derived Boeing 377s to provide fifteen weekly flights between the West Coast and Hawaii. In the early days of stratospheric air travel, Pan American held a monopoly on travel from the U.S. mainland to Hawaii. As the airport replaced the harbor as the launching point for tourist arrivals and departures, Turkey Love adjusted his approach toward attracting clients to match.

Turkey recalled that the Hawaiian Town nightclub in the Pan American Building near the old Honolulu Airport became the new sending off point for leaving tourists, stating:

Pan American Building. You know, the Pan American Building? Across the street, the bank there? Right there. That's back in those days, the dirt road going through there. That was dirt road. Yeah. And even after the ships were pau (after

211 “Pan American Adds New Flights to Honolulu,” Los Angeles Times. May 15, 1949, A11.

212 “Nine-Hour Service to Hawaii Planned,” New York Times. March 14, 1940, 48. 
regular steamship service had ended), we used to go down to the airport, the old airport, the one on this side. You know that Lagoon Drive or whatever you call it? That's the road we took. We used to go all the time, too. Sure. I made about six trips by going down there. These people go downstairs, buy a ticket, I'm on my way to the Mainland. I made six, seven, eight trips like that. ${ }^{213}$

By the early 1950s, air travel had not only increased the ease by which tourists could arrive, but had also made it possible for them to bring a beachboy home with them as a souvenir. Joe Akana’s 1936 trip to Los Angeles as part of the Maharaja of Indore’s entourage marked a unique experience in that time. Only patrons on immense wealth, such as the Maharaja, could afford companion travel for their favorite beachboys. For Turkey Love, travel to the mainland required little more than having drinks one last time with a wealthy enough client. After the first such trip, Turkey accounted for such spontaneity whenever he would take drinks at the Hawaiian Town nightclub, making sure he "had the right clothes on" for air travel. For Turkey's clients, returning with a beachboy represented more than the opportunity to show off a living piece of vacation memorabilia to friends back home. The dark, toned, athletic bodies of the beachboys held their own appeal. Withholding the client's name, Turkey spoke of a particular tourist who would return to the mainland after his yearly trip to Waikiki with a couple of beachboys and lavish them with gifts. Of the experience, Turkey revealed, "And every time we'd go, he would buy us clothes. (Chuckles) Got so every time we went, we'd go empty-handed. Really. Come back with plenty clothes.” Fetishized views of the Native Hawaiian's body fueled the patron's interest in travelling with Turkey and a handful of other beachboys. In the same vein that heteronormative interactions fueled the sexual reimagining and objectification of both Hawaiian men and women's bodies to opposite

${ }^{213}$ Turkey Love, 1691. 
sexed clients, Turkey's patron exhibited a homoerotic purview of the beachboy as a trophy to be clothed and displayed. Turkey and his friends received other gifts along with clothing, including tickets to World Series games and travel between host cities. ${ }^{214}$ For Turkey's patron, dressing the beachboys served as a way to showcase the young men and their bodies in public at sporting events as a demonstration of his affluence. By expecting repeated treatment to gifts and travel from specific clients, Turkey participated in the sexual imaginary created by his patrons. Participating as a consenting party to such exotification for material gains, Turkey wielded his masculinity to his own benefit in the situation.

Through depictions of cross-dressing burlesque performers and as fetishized companions serving as living souvenirs for affluent patrons on the mainland, beachboy sexualities took manifold iterations, well beyond the heteronormative image provided by Walker. Through Joe Akana and Turkey Love’s accounts, a more complex image of Waikiki beachboys' masculinities arose. Beyond the classical image of beachboys as temporary paramours to wealthy divorcées and wealthy daughters, the watermen served as masculine role models to tourists unsteady on the water. Their toned, dark bodies held appeal to both men and women clients. While evidence of explicit homosexual activities did not surface in the beachboys' accounts, homoerotic and homosocial desire fueled the interactions that brought Joe Akana and Turkey Love to the mainland in the entourage of wealthy men. The fetishizing of Native Hawaiian bodies also found prevalence in the advertising strategies both travel writers and local businesses used to create and sell an imagined conception of Waikiki.

${ }^{214}$ Turkey Love 1692. 


\subsection{Fantasies of the Exotic: Gender and Sexuality in Media and Practice}

Imagined conceptions of Hawaii at the turn of the twentieth century shaped the way tourists interacted with beachboys and other locals in Waikiki. Early literary accounts of Hawaii, steeped in paternalistic and romanticized imagery, captured the imaginations of tourist advertisers, travel writers, and ultimately the broader public-atlarge. In the decades bookending the year 1900, notable American literary figures, including Mark Twain, Robert Louis Stevenson, and Jack London, harbored a fascination for Hawaii and produce titles describing their experiences with positive enthusiasm. As the most contemporaneous of the three, Jack London's tales crystallized the stereotypical image of Hawaii in the minds of the article writers and advertisers in the first half of the twentieth century. Jack London visited Hawaii twice. First in 1907 aboard his voyaging yacht, the Snark, as part of a broader tour of the South Pacific, and then again in late 1915, making at that time a more extended stay. During his initial visit, he rented a tent cabin on the premises of the Seaside Hotel in Waikiki. He spent time there gathering inspiration for his collection of South Seas stories, and needed to look no further than beyond his front door, where he observed a group of locals surfing, which he called, “a royal sport for the natural kings of earth.”215 London at once identified Native Hawaiians as somehow both cultured yet more basal and connected to environment. He at first contented himself to observe the surfers at play, awed by their mastery of the sport. Catching their attention, the group offered to teach him how to surf, and he accepted.

${ }^{215}$ Jack London, “A Royal Sport” in The Cruise of the Snark: Jack London's South Sea Adventure. (Santa Barbara: Narrative Press, 2001), 50. 
Though he did not succeed in catching a wave, the experience resonated with him. In his story “A Royal Sport,” he remarked:

Where but the moment before was only wide desolation and invincible roar, is now a man, erect, full-stature, not struggling frantically in that wild movement, not buried and crush and buffeted by those mighty monsters, but standing above them all...flying forward, flying fast as the surge on which he stands. He is a Mercury-a brown Mercury. ${ }^{216}$

Jack London’s depiction of Native Hawaiians as friendly and civilized, yet primitive became an established caricature for nonwhite peoples of Hawaii. London’s observations, similar to other accounts from the time, revealed a romanticized notion of orientalism popular in the late Victorian period into the early twentieth century. ${ }^{217}$ As Hawaii started to grow into a tourist destination, idealized perceptions of the islands dominated advertisements and travel articles of the period.

Early tourist literature crafted a romanticized, racialized vision of Hawaii, promoting its exoticism through idealized observations. Following Jack London’s lead, travel writers sought out "authentic” experiences of their own when visiting Hawaii. However, the experiences they shared revealed their paternal fascination with "native” culture. Viewing a society they saw as vastly different from their own, visiting writers believed that the experiences they captured harkened back to a primitive past. Hawaiian water sports, in particular, found popularity in tourist narratives. Of outrigger canoeing, a travel writer for Vogue wrote, "In padding the Outrigger Canoe, a perilous but exciting sport, the Hawaiian boy, at other times the perfect servant, becomes the perfect

\footnotetext{
${ }^{216}$ London, “A Royal Sport,” 51.

${ }^{217}$ Edward W. Said, Orientalism. (New York: Vintage Books, 1979).
} 
leader.”218 The writers commentary perpetuated a stereotypical image of nonwhite peoples, in this case Native Hawaiian, as child-like and subservient, requiring stern instruction and guidance. As also seen in Jack London's accounts of surfing, water sports provided an opportunity for visitors to imagine an idyllic island culture removed from modern complications. The unique cultural experiences they encountered allowed tourists to romanticize Hawaii as a timeless land immune to the ravages of modernity. The aforementioned travel writer for Vogue captured this sentiment, stating of Honolulu, "It is the most Oriental of Occidental cities, the most Occidental of Oriental; and, since it is so distant from the customary center of human habitation, the eyes of weary men turn towards it wistfully as a haven of escape from the habitual." ${ }^{219}$ The writer's remarks showcased the belief that Hawaii, with its Eastern exoticism, provided the antidote to the pressures of modern, urban Western society. In Hawaii, tourist writers imagined an Edenic paradise peopled by a genteel, naïve population untroubled by the complexities of modernity. In idealized Hawaii, “natives” engaged themselves in traditional sport, and lived as they had for centuries. Partaking in experiences such as surfing and outrigger paddling promoted racialized views that local nonwhite peoples had perfected the skills necessary to partake in such sports through a more basal connection with nature. Tourist advertisements captured and distilled such experiences, further shaping Hawaii’s growth as a vacation destination. Built on racialized observations an pandering to a desire for the exotic, tourist literature reflected the dominant views of Native Hawaiian and Asian 56.

${ }^{218}$ Clayton Hamilton, “Honolulu Holds the Magic Mirror for Mankind.” Vogue, January 1, 1924, ${ }^{219}$ Hamilton, 56. 
people held by the white public at the time. Haole hotel owners perpetuated such caricatures as commonplace through the description of their nonwhite employees.

Born in 1911 in Hale ‘iwa, O‘ahu, Richard Kimball grew up an heir to his family’s hotel business. Beginning his life at the Hale'iwa Hotel on the North Shore of O'ahu, Richard's formative experiences happened within the walls of his family hotels, giving him an intimate experience with the burgeoning tourist culture. Moving to Waikiki in 1917 when his family purchased the Halekulani Hotel, Richard lived full time at the hotel, both observing the rise of lavish tourist experiences and living it firsthand, enjoying nightly dinners in the hotel restaurant and frequent use of its amenities. Immersed in an environment where he only encountered nonwhite peoples in subservient positions, as wait staff, cooks, beach attendants, and maids, his understanding and interactions with these groups reflected the dominant stereotypes perpetuated in tourist literature. From his earliest memories, Richard recalled the Japanese woman who worked in his family's household. He viewed her stay with the family through a paternalistic lens, believing that her employment under them afforded her opportunities she may have lacked otherwise, in particular an education. On the matter, he remarked:

The thing about that was, being with a nice family like that, she was getting her education partly, too. Her English was improved. Mother would explain to her, and all this and that. So, Mother never told me that, but I can just visualize what a help it was for that girl to have someone like Mother and Dad to talk to her about stuff. You don't get all your education in the classroom. A lot of it is by association with people, people that are teachers anyway, natural teachers, it's like private tutoring. So I never thought of her working for five dollars a month as menial. She was just lucky to have a situation like that where she was getting her continued education. She may not have had much at all to begin with. But she was just a wonderful person. Oh, Mother and Dad just thought the world of her. My brother was lucky he had a good babysitter. That's the way things were. ${ }^{220}$

${ }^{220}$ Richard Kimball, oral history interview with Michi Kodama-Nishimoto and Warren Nishimoto, February 12, 1986, Black Point, O'ahu. In Waikiki, 1900-1985: Oral Histories Vol. 1 (Honolulu: Center for Oral History, Social Science Research Institute, University of Hawai 'i, Manoa, 1986), 1716. 
Richard's statements reflected a view of his parents as "natural teachers" to the Japanese "girl” who worked for them. He viewed the supplemental "education" she received as a form of compensation in addition to her meager pay. Richard's hierarchical view toward nonwhite people as requiring education and guidance extended to the wait staff the Halekulani Hotel employed. Lamenting the unavailability of experienced waiters at the Hotel in his youth, Richard noted that his father left training in the hands of the head waiter, whom Richard remembered only as Mr. Ukishima. Mr. Ukishima made the hiring decisions for the dining hall floor, placing issei Japanese employees from his neighborhood in those position. Of Mr. Ukishima, Richard explained, "When he came to be headwaiter, he brought "Nishi," and Kosaki, and one more guy with him. We'd usually get an absolutely green guy come in, make him put on his white uniform and all that, and start coming." 221 Richard's father entrusted his head waiter to train the new employees in restaurant service etiquette. As a test of their waiting skills and response under pressure, new hires served their first few months at the Halekulani working the Kimball family’s personal table. Richard lamented:

And the Kimballs' family table always got that new waiter and couple of others. We'd try and teach him. Ukishima would explain and teach him little bit at first. We had no proper training system. But you put him on that Kimball family table for two or three months, and he'd be a pretty good waiter. He'd be glad to get away from it, too. (Laughs) But he'd catch hell from different members of the family. If he did it wrong, we'd all—my brother was the worst of all. Boy, he'd jump on him and scare the living daylights out of him. Nice, new guy coming in, he [Richard's brother] was awful. ${ }^{222}$

\footnotetext{
${ }^{221}$ Richard Kimball, 1750.

222 Ibid.
} 
The stern treatment of employees extended beyond Richard's brother with his father himself offering stern criticism if a waiter stacked dishes before bussing the table after a meal, or failed to wipe the bottom of a plate before setting it on the tablecloth. The casual tone struck by Richard demonstrated the normalization of such treatment and behavior in his mind. Perhaps in a moment of self-censorship, Richard failed to describe the behavior with which his family subjected the wait staff, instead focusing on his brother's unwarranted maliciousness in particular. The behavior exhibited by the Kimball family towards their nonwhite employees provided a stark example of the prevalence of paternalism in the creation of the Hawaiian tourist paradise. The constructed social hierarchy within Waikiki, and throughout Hawaii, placed wealthy haoles such as Richard Kimball at its apex. Infantilized caricatures of Asian and Native Hawaiian peoples as permanent children needing the most basic instruction affirmed white hegemony in this space. Reimagining the environment of Waikiki as Edenic paradise for the white elite provided space for further imaginaries to take root. In particular, travel writers and poets developed a sexualized image of Waikiki as a place for both unbridled passion and crime.

Once heralded as “Hawaii’s Poet Laureate,” Don Blanding’s obsessive gaze into Waikiki nightlife helped create a gritty, sexualized image of the space in the height of the Jazz Age. Floating on swung rhythms and a pulsing backbeat, Jazz music fueled a cultural phenomenon throughout America in the "roaring twenties." Played everywhere from concert halls to dance halls to living room "petting parties," Jazz became the standard and expectation when it came to nighttime entertainment. 1920s Waikiki provided no exception. Don Blanding captured an image of Waikiki nightlife in his prose 
poem, "Waikiki,” stating, "The area surrounding the two big hotels, the Moana and the Royal Hawaiian, is known as Flappers’ Acre... The jazz bands from the two beach hotels fling dance tunes over Flappers’ Acre. Automobiles swish in and out of the narrow streets, filled with pretty girls and their escorts.”223 Referencing the iconic women’s subculture movement of the Jazz Age, Blanding's accounts identified a specific district, centered on the Royal Hawaiian, as the epicenter of Jazz nightlife in Waikiki. In fact, local musician Johnny Noble, originally the conductor of the Moana Hotel Orchestra, led Jazz ensembles at both hotels throughout the decade. On the subject on his music, a fusion of Jazz and Hawaiian influences called hapa haole music, Noble stated, "Music was the pulse of the people. Warm, fuild, rhythmic, and poignant-it was a common impulse, their greatest emotional outlet and mutual source of enjoyment.”224 Haole visitors took notice of the novel genre, offering praise. After taking in a night of Jazz at the Royal Hawaiian, a travel writer noted, “a Hawaiian orchestra play[ed] the latest “jazz,” interspersed with an occasional native air.”225 Accounts of Waikiki’s nightlife attested to its vibrancy. On a nighttime stroll down Kalakaua Avenue along Blanding’s “Flappers’ Acre,” an observer might have encountered young couples in automobiles listening to the faint din of Hawaiian Jazz compositions, such as Johnny Noble’s “Hula Blues,” escaping from hotel fronts. Using the sexualized image surrounding Jazz music, advertisers and travel writers alike crafted a narrative of Waikiki as a haunt for the pursuit of sexual pleasures.

223 Don Blanding, “Waikiki,” Hula Moons. (New York: Dodd, Mead \& Company, 1930). 209.

224 Guerre Ploner Noble, Hula Blues: The Story of Johnny Noble, Hawaii, Its Music and Musicians. (Honolulu: Tongg Publishing Co., 1948), 60-61.

225 Rosemary Bevan Karelle, "Honolulu: This Hawaiian Paradise Bewitches the Visitor with Its Sea, Its Hills, and Its Magical Moon in a Tropical Night.” Vogue, October 15, 1927, 136. 
Playing on the seductive cachet surrounding Jazz and its infusion to Waikiki nightlife culture, Don Blanding aimed to further develop the district's sexualized image with his 1928 poem "The Virgin of Waikiki." Following the fate of protagonist Anne, a "virgin maid/Who was just this side of of forty,"226 Blanding crafted a sordid narrative of crime and passion. Anne’s description as "Waikiki's one virgin," drew an image of Waikiki as a sexual paradise where patrons could satisfy their desires. Under the influence of a neighbor described as a "dirty cat in a near-by flat/Whose morals were quite elastic,” Anne decided participate in the sexual imaginary drawn by Blanding. However, in common with other depictions of women's sexuality from the time, Anne's tale served as a cautionary one. Choosing a drunk sailor sitting on the beach by the Moana Hotel as her partner for the night, Anne encountered trouble. Choosing not to describe the setting, Blanding ends Anne’s tale as follows:

$\mathrm{OH}$, I can't write of that hectic night, My description would be pallid.

And anyway the things I'd say Don't belong in a proper ballad.

TO THE folks who stay out Mo-ana way Anne's ending is a mystery, And the daily press could only guess At part of her curious history.

BUT The papers state that next morning late, On a beach by the board Pacific, They found Anne dead, BUT the papers said That her smile was BEATIFIC ${ }^{227}$

${ }^{226}$ Don Blanding, The Virgin of Waikiki: A Torrid Tragedy of the Tropics. (Honolulu, Privately Printed, 1928), 5.

${ }^{227}$ Don Blanding, The Virgin of Waikiki, 15. 
Blanding's words offer an invitation to the attentive reader, promising delight and satisfaction to the visitor seeking the thrills of sex and possible danger. The social construction of Waikiki as an urbanized tourist paradise containing every sort of sin and pleasure promoted by early travel writers proved a self-fulfilling prophecy. As Waikiki blossomed into the twentieth century as a package-deal paradise, eager arrivals from all walks of life picked up the narrative of Waikiki where Don Blanding, Jack London, and other left off. They lived out their fantasies of the exotic along city streets paved over duck ponds and working-class neighborhoods that had come before. Both iterations of the space manifest human capability to engineer the landscape to their purposes. As the tourist fantasy came to dominate the landscape in the early-twentieth century, the shapers of that world set in motion the gears to guarantee Waikiki's continued evolution. 


\section{CHAPTER FIVE: CONCLUSION}

Oral histories provide a striking balance between the personal and the historical. In ways that archival print materials do not, oral histories enter the realm of the emotional to invoke worlds otherwise unknowable to persons who did not share in the same lived experience. From the voices of the nonwhite residents shared in this narrative, images ignored by conventional print media arise. The organic interpretation of interview transcripts presented the reader with the opportunity to observe the process of talking story. Through preserved conversational detail, the reader observed Miyo Asuka disembark from the decks of the Chiyo Maru into U.S. Immigration Office quarantine in Honolulu Harbor. Along bumping streetcar tracks, Rusty Holt revealed his prankster ways, taking aim at the Japanese-owned businesses in Hamohamo with rotten duck eggs. Coupled with legislative history and print records, personal accounts took on greater gravity as tools to measure colonial oppression and cultural erasure.

Recapitulating trends initiated by Haunani-Kay Trask and Noenoe K. Silva, the project produced narratives closer to the "alternate histories" that had failed to reach Western historiography in the past. Following successive generations of knowledge loss due to colonial aggression and control over the historical and archival records, this project is indebted to the efforts of the activists and scholars who initiated the Hawaiian Renaissance and renewed epistemological lines to our past. Due to its emphasis on anticolonial, 'local' identities, this project privileged the voices of Native Hawaiian and Asian nonwhite residents to the exclusion of others. In particular, the purposeful absence of accounts from military servicemen provides context to who falls within the definition of 'local' as used by this work. The establishment of Fort DeRussy in the Kalia 
neighborhood Waikiki in 1911 did reshape cultural interactions in the area. However, transient by nature of their assignments and resistant in their own right to cultural amalgamation, military members appear in this work as interlopers, as the initiators and targets of aggression, or as situational backdrop to everyday life.

Perhaps prophetically, Jack London wrote in a correspondence during his 19151916 visit to Waikiki, “I’m glad we’re here now...For someday Waikiki Beach is going to be the scene of one long Hotel.”228 Waikiki today, with its high-rise hotels and apartments, constant traffic, and crowded beach, owes much of its appearance to the social reengineering efforts of Lucius Eugene Pinkham, Walter F. Dillingham, and other like-minded politicians and industrialists who saw Waikiki and its people as exploitable resources. The Ala Wai Canal diverted stream waters away from taro farms and fishponds, dispossessing Native Hawaiian and local Asian farmers of land and livelihood. Once dried, Waikiki gained its current grid pattern as part of Pinkham's dream of creating an urban resort paradise.

Competing views of the Pacific Basin held by Inagaki Manjiro and Alfred Thayer Mahan as either a seascape of opportunity and plenty or scarcity and exploit, defined colliding Japanese and American maritime ambitions in the late nineteenth century. Political power of policymakers and individual action of migrant laborers seeking new fortunes worked together to shape the Pacific into a multicultural, international domain. In Hawaii, new arrivals from Japan encountered adversity from racist, populist sentiments held by territorial and U.S. policymakers and industrialists. Arriving from

${ }^{228}$ Jack London, Letters of Jack London, ed. Earle Labor, Robert C. Leitz, III, and I. Milo Shepard (Stanford: Stanford University Press, 1988), 1565. 
agricultural background to serve as contract labor in the pineapple and sugarcane industries, personal accounts revealed experiences of integrating into an existing multiracial working class. Shared cultural experiences including plantation harvest activities, Japanese celebrations, and the practice of talking story all contributed to successful amalgamation of Japanese new arrivals with the multiracial working class society.

Social and commerce organizations affected the positive outreach necessary for improved community interactions between Japanese and local nonwhite residents. In common with Japanese social organizations in the neighborhood, Japanese business owners promoted improved cultural understanding between Japanese residents and the rest of the community. Through positive interaction with customers and neighbors, Japanese-owned business owners gained acceptance within their communities in ways that defied political rhetoric from the period. Observations of the tanomoshi system revealed Japanese distrust of and lack of access to the official capitalist banking system. In an attempted to rein in Japanese economic independence, territorial politicians took denigrated tanomoshi system in the press as a form of usury. Examination of territorial law revealed an intent to outlaw nontraditional lending systems in order to restrict access to credit to individuals who qualified under the official banking system in place.

Personal accounts from professional beachboys uncovered manifold masculinities on display. From humor and horseplay from school-ages gang members to sexually-proficient watermen who attracted men and women clients, the tales of Waikiki's beachboys extended far beyond the subservient and feminized depictions they received in print media. Through fights and sports activities with other neighborhood 
gangs and haole military members, Waikiki gang members engaged other men in contest of sexual aggression, describing a need to "protect" perceived fragile femininity. Relations between beachboys and their wealthy clients broke heteronormative as well as racial norms. Lavish gifts such as expensive clothes and companion travel to the mainland marked the way wealthy men made living souvenirs of the beachboys, fetishizing their dark, toned bodies. Homoerotic and homosocial desire fueled the interactions that brought the young watermen to the mainland. The personal accounts of local residents, beachboys, and the haole elite revealed complex, multifarious manifestations of sexuality beyond reductionist heteronormative binaries.

For the social engineers who keep the Waikiki imaginary alive today, combating beach erosion remains a constant effort. Man-made seawalls protect the shore from the full force of Waikiki's surf. As recently as 2012, 27,000 cubic feet of sand had to be pumped in from off shore to restore the beachfront. According to the Hawaii Tourism Authority, a record 8.3 million visitors came to Hawaii in 2014, collectively spending $\$ 14.7$ billion dollars whilst there. ${ }^{229}$ Waikiki serves today as the gateway to that industry as the most popular Hawaiian destination for first-time visitors. Though artificial in every sense, Waikiki remains an icon of Hawaii tourism.

229 “December 2014 Visitors Stat Press Release,” Hawaii Tourism Authority, January 29, 2015. 


\section{Bibliography}

“Alleged ‘Gang’ Holds Sway at Waikiki Beach.” Honolulu Star Bulletin. June 1, 1916.

“Big Hapai-ko Dance Coming,” The Garden Isle. September 26, 1911, 1.

“Carbo-Loading, Hawaiian Style,” New York Times. November 12, 2008.

“Cold Will Keep Maharajah Here Another Week,” Los Angeles Times. November 22, 1936.

“Dangerous to Health,” Hawaiian Star. April 25, 1898, 1.

“December 2014 Visitors Stat Press Release,” Hawaii Tourism Authority, January 29, 2015.

“Dr. Soyeda Says His Mission Is One of Peace,” Honolulu Star-Bulletin. May 19, 1913.

“Enthusiastic Democrats,” Daily Alta California. October 26, 1884.

"Hui Nalu Show Riotous Fun with Mirth, Music and Dancing,” The Honolulu StarBulletin. February 12, 1914.

“Immigration Act of 1924,” United States Statues at Large. Sixty-Eighth Congress, Session I, Chapter 190.

“Japanese Will Offer Great Lantern Parade,” Honolulu Star-Bulletin, December 14, 1916.

“Keaweamahi Adds to His Collection of Lives Saved at Beach,” Hawaiian Gazette. July 2, 1918.

“Kindergartens to Receive Aid from Japanese,” Honolulu Star-Bulletin. December 2, 1916.

“Maharajah Expected at San Diego,” Los Angeles Times. November 9, 1936.

“Maharajah of Indore Sails for Honolulu,” Los Angeles Times. October 12, 1936.

“McBryde Wins Hapai Ko Contest,” The Garden Isle. June 3, 1919, 1.

“Nine-Hour Service to Hawaii Planned,” New York Times. March 14, 1940.

“Noted Japanese Says America Must Take Lead in Pace Work,” Honolulu Star-Bulletin. November 2, 1915.

“Officers Burn Squatters’ Huts,” Hawaiian Gazette. April 14, 1914. 
“One of Hawaii’s Captains of Finance,” The Pacific Commercial Advertiser. July 19, 1902.

“Order of Mayor as to Soldiers Causes Trouble,” Hawaiian Gazette, May 7, 1915.

"Pan American Adds New Flights to Honolulu," Los Angeles Times. May 15, 1949.

"Pinkham Plan to Reclaim Waikiki to be Tried," The Pacific Commercial Advertiser. March 16, 1906, 5.

"Pinkham Plans the Reclamation of All Waikiki," Evening Bulletin. February 21, 1906, 1. Chronicling America: Historic American Newspapers. Lib. of Congress.

"Plantations on Oahu Tied Up by Strike,” Maui News. January 23, 1920.

“Senate Approve Waikiki Commission,” Hawaiian Gazette. May 4, 1917.

“Sluiced Lagoon Water into Waikiki Water and Drove Fair Bathers Away.” The Pacific Commercial Advertiser. February 16, 1913. Chronicling America: Historic American Newspapers. Lib. of Congress.

“Tanomoshi Ruins Japanese,” Evening Bulletin. April 26, 1909.

“The City of Tokio,” Pacific Commercial Advertiser. February 9, 1885.

“The Japanese Immigrants,” Daily Bulletin. February 9, 1885.

“Truth About Waikiki Beach,” Los Angeles Times. June 6, 1920.

“What About the 1918 Mid-Pacific Carnival?” Honolulu Star-Bulletin, June 22, 1918.

“What Sargent Had to Say,” The Hawaiian Star. May 20, 1903, 5.

Akana, Joe, Waikiki, 1900-1985: Oral Histories Vol. 1. By 'Iwilani Hodges and Michi Kodama-Nishimoto, March 8, 1985. Honolulu: Center for Oral History, Social Science Research Institute, University of Hawai 'i, Manoa, 1986.

Andrews, Thomas G., Killing for Coal: America's Deadliest Labor War. Cambridge: Harvard University Press, 2008.

Annual Report of the Surgeon General of the Public Health Serivce of the United States, 1914 (Washington: Government Printing Office), 119.

Aoki, Harold, Waikiki, 1900-1985: Oral Histories Vol. 1. By Michi Kodama-Nishimoto, March 19, 1985. Honolulu: Center for Oral History, Social Science Research Institute, University of Hawai 'i, Manoa, 1986.

Asuka, Miyo, Waikiki, 1900-1985: Oral Histories Vol. 1. Michi Kodama-Nishimoto, February 20, 1985. Honolulu: Center for Oral History, Social Science Research Institute, University of Hawai'i, Manoa, 1986. 
Bader, Esther, Waikiki, 1900-1985: Oral Histories Vol. 1. By Michi Kodama-Nishimoto March 6, 1985. Honolulu: Center for Oral History, Social Science Research Institute, University of Hawai'i, Manoa, 1986.

Bernice Chow Tominaga, Waikiki, 1900-1985: Oral Histories Vol. 1. By Michi Kodama-Nishimoto, February 5, 1986. Honolulu: Center for Oral History, Social Science Research Institute, University of Hawai 'i, Manoa, 1986.

Blanding, Don “Waikiki,” Hula Moons. New York: Dodd, Mead \& Company, 1930. . The Virgin of Waikiki: A Torrid Tragedy of the Tropics. (Honolulu, Privately Printed, 1928.

Chakrabarty, Dipesh, Provincializing Europe: Postcolonial Thought and Historical Difference. Princeton: Princeton University Press, 2000.

Cheney, Albert Loren, Personal Memoirs of the Home Life of the late Theodore Roosevelt. Washington: The Cheney Publishing Company, 1919.

Clarke, Mary Ellen Kealohapauole, Waikiki, 1900-1985: Oral Histories Vol. 1. By Warren Nishimoto, May 20, 1985. Honolulu: Center for Oral History, Social Science Research Institute, University of Hawai 'i, Manoa, 1986.

de Certeau, Michel, The Practice of Everyday Life. Translated by Steven Rendall. Berkeley: University of California Press, 1984.

Desmond, Jane C., Staging Tourism: Bodies on Display from Waikiki to Sea World. Chicago: University of Chicago Press, 1999.

Dresner, Jonathan, "International Labour Migrants' Return to Meiji-era Yamaguchi and Hiroshima: Economic and Social Effects.” International Migration 46 (2008).

Ernest Steiner, Waikiki, 1900-1985: Oral Histories Vol. 1. By Michi KodamaNishimoto, March 5, 1985. Honolulu: Center for Oral History, Social Science Research Institute, University of Hawai' $i$, Manoa, 1986.

Feeser, Andrea and Chan, Gaye. Waikiki: A History of Forgetting and Remembering. University of Hawaii Press, 2007.

Foucault, Michel, The History of Sexuality. Vol. I: An Introduction. Translated by Robert Hurley. New York: Random House, 1978.

Gamayo, Dardenella Mae, The Closing of Sugar Plantations: Interviews with Families of Hamakua and Kau, Hawaii. By Warren Nishimoto, January 15, 1997. Honolulu: Center for Oral History, Social Science Research Institute, University of Hawai ' $i$, Manoa, 1997.

Hamilton, Clayton, “Honolulu Holds the Magic Mirror for Mankind.” Vogue. January 1, 1924. 
Hau ofa, Epeli, “Our Sea of Islands,” in A New Oceania: Rediscovering Our Sea of Islands, Edited by E. Waddell, V. Naidu, and E. Hau ofa. Honolulu: University of Hawaii Press, 1993.

Hogue, Rebecca, "Cultural Identity and Liminal Places in Contemporary Literature of Hawai 'i” in Rocky Mountain Review 66 (Summer 2012).

Holt, Rusty, Waikiki, 1900-1985: Oral Histories Vol. 1. By Michi Kodama-Nishimoto, February 26, 1985. Honolulu: Center for Oral History, Social Science Research Institute, University of Hawai 'i, Manoa, 1986), 785.

Inagaki, Manjiro, Japan and the Pacific and the Japanese View of the Eastern Question. London: Scribner and Welford, 1890).

Judd, Henry P., Men and Women of Hawaii, 1954: A Biographical Encyclopedia of Persons of Notable Achievement, An Historical Account of the Peoples Who Have Distinguished Themselves Through Personal Success and Through Public Service. Honolulu: Honolulu Business Consultants, 1954.

K. Silva, Noenoe K., Aloha Betrayed: Native Hawaiian Resistance to American Colonialism. Durham: Duke University Press, 2004.

Kahanamoku, Louis Waikiki, 1900-1985: Oral Histories Vol. 1. By Warren Nishimoto, May 20, 1985. Honolulu: Center for Oral History, Social Science Research Institute, University of Hawai'i, Manoa, 1986.

Karelle, Rosemary Bevan, "Honolulu: This Hawaiian Paradise Bewitches the Visitor with Its Sea, Its Hills, and Its Magical Moon in a Tropical Night.” Vogue, October 15, 1927.

Kimball, Richard, Waikiki, 1900-1985: Oral Histories Vol. 1. By Michi KodamaNishimoto and Warren Nishimoto, February 12, 1986. Honolulu: Center for Oral History, Social Science Research Institute, University of Hawai`i, Manoa, 1986.

Kodama-Nishimoto, Michi, Nishimoto, Warren, and Oshiro, Cynthia A., Talking Hawai 'i's Story: Oral Histories of an Island People. Honolulu: University of Hawaii Press, 2009.

Korhonen, Pekka, “The Pacific Age in World History.” Journal of World History 18, no. 1 (Spring, 1996).

Kusunoki, Helen, Waikiki, 1900-1985: Oral Histories Vol. 1. By Michi KodamaNishimoto, May 16, 1986. Honolulu: Center for Oral History, Social Science Research Institute, University of Hawai'i, Manoa, 1986.

Laws of the Republic of Hawaii Passed by the Legislature at its Session,1896. Honolulu: Hawaiian Gazette Company, 1896 
Laws of the Territory of Hawaii passed by the Legislature. Session Laws, 1917. Honolulu: Territory of Hawaii Legislature, 1917.

Laws of the Territory of Hawaii passed by the Legislature. Session Laws, 1918.

Honolulu: Territory of Hawaii Legislature, 1918.

Laws of the Territory of Hawaii passed by the Legislature. Session Laws, 1905.

Honolulu: Territory of Hawaii Legislature, 1905.

London, Jack, “A Royal Sport” in The Cruise of the Snark: Jack London's South Sea Adventure. Santa Barbara: Narrative Press, 2001.

. "A Royal Sport” in The Cruise of the Snark: Jack London's South Sea Adventure. Santa Barbara: Narrative Press, 2001.

. "The Yellow Peril," in Revolution and Other Essays. London: Mill and Boon, 1910.

. Letters of Jack London. Edited by Earle Labor, Robert C. Leitz, III, and I. Milo Shepard. Stanford: Stanford University Press, 1988.

Love, Alan Turkey, Waikiki, 1900-1985: Oral Histories Vol. 1. By 'Iwilani Hodges, May 14, 1985. Honolulu: Center for Oral History, Social Science Research Institute, University of Hawai'i, Manoa, 1986.

Mahan, Alfred Thayer, The Influence of Sea Power upon History, 1660-1783. London: Sampson, Low, Marston, 1890.

. The Problem of Asia and Its Effect upon International Politics London: Sampson, Low, Marston, 1900.

Moriyama, Alan Takeo, Imingaisha: Japanese Emigration Companies and Hawaii, 18941908. Honolulu: University of Hawaii Press, 1985.

Mckinzie, Adelaide, Waikiki, 1900-1985: Oral Histories Vol. 1. By Warren Nishimoto. Honolulu: Center for Oral History, Social Science Research Institute, University of Hawai`i, Manoa, 1986.

Melendy, H. Brent, "The Controversial Appointment of Lucius Eugene Pinkham, Hawaii's First Democratic Governor.” The Hawaiian Journal of History, vol. 17 (1983).

Morse, Harold, “Obituaries: Rusty Holt, 94, avid sportsman, deep local roots.” Honolulu Star Bulletin. March 20, 1999.

Noble, Guerre Ploner, Hula Blues: The Story of Johnny Noble, Hawaii, Its Music and Musicians. Honolulu: Tongg Publishing Co., 1948. 
Pinkham, Lucius E., Reclamation of the Waikiki district of the city of Honolulu, Territory of Hawaii: Recommendations, maps, plans and specifications. Honolulu: Hawaiian Gazette, 1906.

Report of the Commissioner of Labor on Hawaii, 1902. Washington: Government Printing Office, 1903.

Report of the Superintendent of Public Works to the Governor of the Territory of Hawaii. Honolulu: Paradise of the Pacific Press, 1918.

Revised Laws of Hawaii: Comprising the statutes of the Territory, consolidated, revised and annotated. Honolulu: Hawaiian Gazette, 1905.

Richards, Mervin, Waikiki, 1900-1985: Oral Histories Vol. 1. By Michi KodamaNishimoto, March 7, 1985. Honolulu: Center for Oral History, Social Science Research Institute, University of Hawai'i, Manoa, 1986.

Said, Edward W., Orientalism. New York: Vintage Books, 1979.

Scott, J.W. Roberston, The Foundations of Japan: Notes Made During Journeys of 6,000 Miles in the Rural Districts as a Basis for a Sounder Knowledge of the Japanese People. London: J. Murray, 1922.

Scott, James C., Seeing Like a State: How Certain Schemes to Improve the Human Condition Have Failed. (New Haven: Yale University Press, 1998), 3-4.

.Weapons of the Weak: Everyday Forms of Peasant Resistance. New Haven: Yale University Press, 1985.

Senate Journal Ninth Legislature of the Territory of Hawaii, Special Session 1918. Honolulu: Tongg Publishing Co., 1918.

Smith, Bernard, European Vision and the South Pacific. New Haven: Yale University Press, 1985.

Smith, Stacey L., Freedom's Frontier: California and the Struggle over Unfree Labor, Emancipation, and Reconstruction. Chapel Hill: University of North Carolina Press, 2013.

Steer, Doveline “Tootsie” Notley, Waikiki, 1900-1985: Oral Histories Vol. 1. By 'Iwilani Hodges, April 1, 1985. Honolulu: Center for Oral History, Social Science Research Institute, University of Hawai ‘i, Manoa, 1986.

Stern, Alexandra Minna, Eugenic Nation: Faults and Frontiers of Better Breeding in Modern America. Berkeley: University of California Press, 2005.

Thrum, Thos. G., Hawaiian Almanac and Annual for 1904. Honolulu: Thos. G. Thrum Company, 1903. 
Thurston, Lorrin A., "Hawaii: What it is. What it has. What it needs. Its great problem." Los Angeles Times. January 21, 1923.

Trask, Haunani-Kay, From a Native Daugther: Colonialism and Sovereignty in Hawai 'i. Monroe: Common Courage Press, 1993.

Van Vort, Bessie and Van Vort, Marie, The Woman Who Toils: Being the Experiences of Two Gentlewomen as Factory Girls. New York: Doubleday, Page \& Company, 1903.

Vida, Earl Waikiki, 1900-1985: Oral Histories Vol. 1. By Warren Nishimoto, March 18, 1985. Honolulu: Center for Oral History, Social Science Research Institute, University of Hawai‘i, Manoa, 1986.

Walker, Isaiah Helekunihi, "Hui Nalu, Beachboys, and the Surfing Boarder-lands of Hawaii.” The Contemporary Pacific 20, No. 1 (2008).

. Waves of Resistance: Surfing and History in Twentieth Century Hawaii. Honolulu: University of Hawaii Press, 2011.

Wiegel, Robert L., "Waikiki Beach, Oahu, Hawaii: History of Its Transformation from a Natural to an Urban Shore.” In Shore and Beach 76 (Spring 2008), 3.

Wong, Ella Lila, Waikiki, 1900-1985: Oral Histories Vol. 1. By Warren Nishimoto, June 16, 1986. Honolulu: Center for Oral History, Social Science Research Institute, University of Hawai‘i, Manoa, 1986.

Yasumatsu, Toshio, Waikiki, 1900-1985: Oral Histories Vol. 1. By Michi KodamaNishimoto, February 26, 1985. Honolulu: Center for Oral History, Social Science Research Institute, University of Hawai`i, Manoa, 1986.

Yee, Ah Buck, Waikiki, 1900-1985: Oral Histories Vol. 1. By 'Iwilani Hodges, June 2, 1986. Honolulu: Center for Oral History, Social Science Research Institute, University of Hawai‘i, Manoa, 1986.

Yoshimura, Masayuki, Waikiki, 1900-1985: Oral Histories Vol. 1. By Michi KodamaNishimoto, April 23, 1986. Honolulu: Center for Oral History, Social Science Research Institute, University of Hawai`i, Manoa, 1986. 